\title{
The Desert's Role in the Formation of Early Israel and the Origin of Yhwh
}

\author{
'UZI AVNER \\ The Dead Sea and Arava Science Center, Israel
}

\begin{abstract}
The origin of ancient Israel has been questioned and intensively discussed for almost two centuries by many researchers, from two main schools of thought. One believes the early Israelites came from outside the Land of Cana'an and conquered it, while the other believes they rose from within Cana'an, forming a new polity and culture. Scholars are likewise divided whether the Israelite God, Yhwh, originated from the Near Eastern cultural environment or from the desert. A multitude of studies has been dedicated to these two themes, usually separately. This article attempts to examine the connection between the two through several themes: desert roots in the culture of ancient Israel, the origin of Yhwh, Asiatics in Sinai and the Negev, desert tribes and the copper industry, the location of biblical Paran, Nabataean data from Sinai which illuminate biblical issues, and others. By including materials which were previously underutilized or overlooked, these themes may be integrated to form a reasonable scenario of a chapter in the history of early Israel.
\end{abstract}

KEYWORDS Se‘ir, Negev, Sinai, Paran, Shasu, Israel, Yhwh, copper

\section{Israel's Origin}

There is a broad agreement that in many aspects, the ancient nation of Israel $^{1}$ was quite unusual, as well as its God. However, a long and ongoing debate still questions the origins of both. At least eleven theories have been suggested by scholars as to the origin of Israel; generally and superficially, they are divided into two main 'traditional' groups. One sees Israel as created by newcomers, who either conquered Cana'an militarily, as described in the book of Joshua, ${ }^{2}$ or took it over through a peaceful settlement process, as reflected from the book

1 The frequent use of "Israel" in this article is somewhat problematic, since most of the timespan discussed here is prior to the creation of the Israelite kingdom. The term "proto-Israelites," which is often used in publications, would be more appropriate, but this would be too redundant. The reader should be aware that the term "Israel" prior to the tenth century BCE does not addresses an organized people. However, an ethnic group named "Israel" did exist in the thirteenth century BCE (see below). Albright (1935, 1939); Wright (1957, 69-84); Yadin (1982). 
of Judges. ${ }^{3}$ The other group views Israel as originating within Cana'an, from local ethnic elements, Cana'anites, and others. ${ }^{4}$ According to some scholars, the biblical narrative of the creation of Israel (the Patriarchs, the Exodus, and the conquest) was just a legend, written in the seventh century BCE or later, and has no historical background. ${ }^{5}$

A third option has emerged and gained broad agreement. It states that Israel was created during a long ethnogenesis process from a variety of groups that gathered from different regions: Cana'anites, 'Apirw/Habirw, ${ }^{6}$ Hitites, Hurites, Amorites, desert tribes, the Exodus people, "Sea People,"” and others. These heterogenic groups utilized a historical opportunity following the decline of the Near Eastern empires, especially the demise of the Egyptian domination over Cana'an during the twelfth century BCE. This view was first presented by Petrie (1906, 196-201), continued by a number of later scholars, ${ }^{8}$ and further developed by Killebrew $(2005,2006,2017)$ as the "mixed multitude theory," a term adopted from the biblical narrative ( ערב רב Exodus 12:38) for those who joined Israel on departure from Egypt. ${ }^{9}$ Some of the tribes were actually present in Cana'an before the widely believed time of the Exodus (second half of the thirteenth century BCE). ${ }^{10} \mathrm{~A}$ close and balanced view has been presented by K.L. Sparks (2007), finding cultural and religious roots in Israel as originating both in Cana'an and in the desert. A number of scholars see the desert groups as an essential element in this "mixed multitude." 11

The "mixed multitude" option seems most realistic, but there is still room for debate on the identity of the 'core group' and on the role of each ethnic element in the formation process of early Israel.

\section{Brief Notes on the Exodus}

Naturally, the origin of Israel cannot be discussed without addressing the Exodus. A multitude

3 Alt (1966); Weippert (1971); Aharoni (1982a, 153-80, 1982b); 'A. Mazar 1985 (1985, 1990, 295-367; 2007); Zertal (1987, 158-61, 1991, 1994); Rainey (1995); Levy \& Hall (2002); Faust (2015). A combination of both theories was also suggested, i.e., a long settlement process with occasional wars waged by the settlers against Cana'anite cities (Bright [1959] 1981, 120-27; Aharoni 1979, 191-285); Mazar (1990), 329-38; Hasel (2008); Ben-Tor (2016), 118-126].

4 Mendenhall (1962); Gottwald ([1979] 1999, 489-621); Aharoni (1982a, 191-95, 209-67, 1982b); Finkelstein (1988, 1994, 2015); Rainey (1995); Faust (2015).

$5 \quad$ Lemche (1998, 2013); Thompson (1999); Finkelstein \& Silberman (2001); Na'aman (2005, 317-79).

6 There is no debate on the nature of the 'Apirw/Habirw of the Akkadian and Egyptian sources, as people lacking real estate, who were present and active in Cana'an (and beyond) mainly during the Late Bronze Age. For the debate on their identification with the Hebrews, see, e.g., Albright (1968, 64-79); de Vaux ([1971] 1978, 209-16); Weippert (1971, 63-102); Cazalles (1973); Na'aman (1986); Astour (1999). It can be briefly said that some of them joined the new, gradually forming entity named "Israel."

7 The Dannu/Danuna, of the "Sea People," may have turned to the tribe of Dan (Yadin 1965; Rendsburg 1997, 449-50).

8 Bright ([1959] 1981, 120-27); Rendsburg (1997); Dever (1993, 2003, 217-21, 236-7); Levy \& Hall (2002, 110); Hendel (2002, 46-52); Na'aman (2005, 315-44); 'A. Mazar 2007 (2007, 94-95); Faust (2015). Gottwald ([1979] 1999, 455-59) saw all the Exodus Proto-Israelites as a "mixed multitude," including the Shasu and 'Abiru.

9 Another interpretation of "mixed multitude," based on other occurrences of the term, argue that they were mainly foreign mercenaries in the Egyptian army who married Israelite women (Bar 2008).

10 Alt (1924); Aharoni (1962); Edelman (1992); Herion (1992); van der Veen, in press, and see Note 6. For various theories and a wide agreement on the time of the Exodus, see Geraty (2015), with references.

11 Giveon (1964, 1967, 1971, 262-71); Helck (1968); Weippert (1974); Mettinger (1990); Ahituv (1998); Redford (1992, 275-80); Rainey (1995, 490-96; 2008a, 2008b); Rendsburg (1997); Levy \& Hall (2002); Mazar (2007, 95); Faust (2015). 
of studies attempted to reveal the reality behind the story; ${ }^{12}$ but here it can be related in short notes only. On one hand, it is well known that the Exodus narrative contains many inconsistencies, such as different versions for almost every major detail of the story. Therefore, some scholars reject its historical value (see, e.g., Note 5). On the other hand, the narrative contains many realistic details concerning both the Egyptian and the desert parts of the story, ${ }^{13}$ so it cannot be totally ignored. Elements in the narrative were probably preserved as oral traditions of different groups at different times. When these were later fused into a national epos, the different versions were not eliminated (see e.g., Petrie 1906, 196-201).

Considering the accumulating information on the archaeology and history of Israel, the Exodus from Egypt can now be seen as one element in a complex and long process of the nation's creation (see Dever 2003; Finkelstein and Mazar 2007, 51-55), which accords with the "mixed multitude theory" (and see further below).

\section{The Desert's Role in the Formation of Early Israel}

If the view of early Israel as a "mixed multitude" is accepted, the interest of this article, as stated above, is in the desert component of the conglomerate. Many aspects in Israel's culture and ethnic identity reflect desert roots. Each one deserves a thorough analysis; a few points are presented here:

1. The word "desert" ( מרבר) appears in the Bible 268 times; other terms appear as well: 'arabah (52), ziah (18), and yeshimon (13). The numbers alone may have no significance; however, they become meaningful when compared to the seldom mentions of the desert in the multitude of ancient Near Eastern records.

2. The tribal social structure of Israel is mainly typical to desert societies. Frequent terms like בני יהורה, בני ישראל, בנ קיני,בני אפרים ("sons of Judah," "sons of Israel," "sons of Qeni," "sons of Ephraim," etc.) are tribal terms, much like the names of Bedouin tribes-Banu Jarah, Banu Suheila, etc. The desert tribal origin of groups in Israel may explain the egalitarian ethos, ideology of simplicity, and the "primitive democracy" of the Judges Period, as it is studied from both biblical sources and the material culture of Iron Age Israel. These characteristics perpetuated in Iron Age II, even though the society became more stratified. ${ }^{14}$ The ideology of simplicity is best demonstrated by the desert clan Rechabites (Jeremiah 35:6-9) (De Vaux [1971] 1978, 14-15), who saw the simple lifestyle as a source of longevity, i.e., quality of life. The same ideology is expressed later, in the first literary description of the Nabataeans in their early days, by Hieronymus of Cardia (late fourth century BCE, quoted in Diodorus 2. 48. 1-4). For them, simplicity was a way to protect their freedom. The tribal framework of Israel, referring to the northern league of ten tribes, is well reflected in the "song of Deborah" (Judges 5). It is considered among the oldest sources in the Bible (e.g., Stager 1989), probably close in time to the first occurrence of the ethnic entity "Israel" in Cana'an, first on the often

12 On the Exodus see, e.g., 43 articles in Levy et al. (2015), each with ample references.

13 E.g., Bietak (1987), (2015); Hoffmeier (1997); Kitchen (Kitchen 1998); Shupak (2011); B. Sparks (2015); Rendsburg (2015); Schneider (2015); Römer (2015, 48-50).

14 More on the egalitarian nature of early Israel, see Gottwald (Gottwald [1979] 1999, 608-23, 692-9); Faust (Faust 2006a, esp. 92-107), and in press. 
overlooked "Berlin Stelae" No. 21687 of Ramses II, approx. 1250 BCE, ${ }^{15}$ and then in the renowned Merenptah Stela, 1208-9 BCE. ${ }^{16}$

1. Numerous small details of everyday life, customs, and rules written in the Bible have direct parallels in the Bedouin culture (Nyström 1946; Bailey 2018). Only writers with a deep desert background could have described these, even if they only absorbed them from their familial narratives. These 'mundane' details were rooted deep enough in the Israelite culture to survive the later editions of the Bible.

2. The "tent" (אהל) and related terms are often mentioned in the Bible (325 times). The term was still applied to a "house" long after the Israelites abandoned tents (besides the Rechabites). ${ }^{17}$ Many terms stemming from "tent" continued to be regularly used throughout the First Temple period (Homan 2002). Again, only writers with a lively memory of living in tents could have written such details that even survived the later editions of the Bible. The importance of the tent is demonstrated in the highly detailed description of the Tabernacle's construction (12 chapters; Exodus 25-31, 35-40), compared to the short descriptions of construction of the Temple in Jerusalem-one chapter in 1Kings (No. 6) and two parallel chapters in 2Chronicles (2 and 3). The importance of the tent is also highlighted by the refusal of Yhwh to move from his tent to a "house" (i.e., temple, Samuel 17:1-7; 1Chronicles 17:1-5). The legendary nature of the story is obvious, but it still reflects some reality. In the early 1970s, Rahat, the first sedentary Bedouin city, was built in Israel, north of Be'er Sheba'. Young people willingly moved into the newly built houses, but the elders refused to do so and pitched their tents next to their children's houses (figure 1). One can imagine similar reactions in the Iron Age I Israel as a source for the story of Yhwh and his tent.

Several researchers pointed to the nomads' tent as the source for the "four-room house," typical of the Israelite architecture, the image of which was taken from the present-day, long, rectangular Bedouin tents. ${ }^{18}$ This connection may have served as another point in favor of the desert origin of Israelite tribes, but this is not the case. In the Negev, thousands of remains of tents are found in hundreds of tent camps. All are circular, approx. 4 meters in diameter, and are dated approx. from 5000 BCE to 1500 CE (Avner 1979, forthcoming152-4, 2002, 12, 2019, 606; Holzer and Avner 2000). The large, rectangular Bedouin tent (figure 1) was probably first introduced into the Negev and Sinai from the Arabian Peninsula, following the Ottoman conquest of the Near East, in the early sixteenth century CE. However, the "four-room house" may have still been related to the desert (see below).

1. According to the biblical writers' viewpoint, the Israelite tribes had close kinship relations with the desert tribes and clans, as reflected from genealogical lists (e.g., Genesis 36,1 Chronicles 1-9) and numerous other verses. Genealogical ties were not necessarily

15 Helck (1968, 479); van der Veen et al. (2010); van der Veen in press; Zwickel \& var der Veen (2017).

16 For the text of Merenptah stela, see, e.g., ANET 376-8. For discussions on the stela, see, e.g., Stager (1985); Ahlström (1985); Redford (1986); Kitchen (1997); Hasel (2008). On attribution of reliefs from Karnak to Merenptah and identification of Israelites, see Yurco (1997a, 1997b); Rainey (2001); Hasel (1994, 2008); Faust (2006a, 159-66, 185-6); Dever (2009).

17 In a recent visit to Beduins in Sinai (November 2019), they referred to their block-built houses as "hima," i.e., "tent," similarly to the frequent use of "tent" in the Bible.

18 Kempinski (1978, 36); Fritz (1983, 64); Herzog et al. (1984, 75-76); Finkelstein (1988, 255-9); Levi \& Holl (2002, 91-92). 


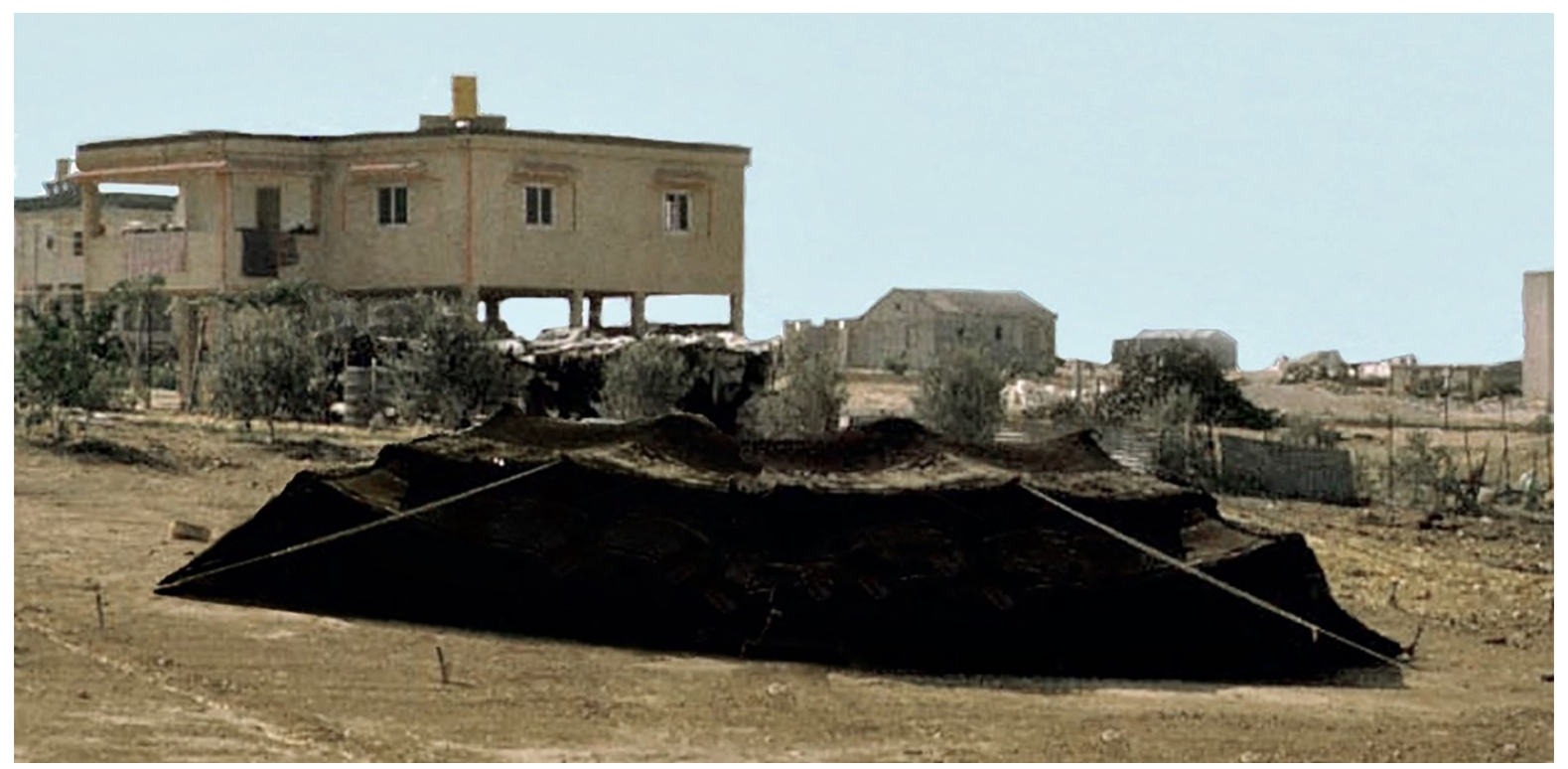

Figure 1 Rahat, north of Be'er Sheva', 1976: a Bedouin tent for the elders is pitched next to their children's house (photograph by Orna Goren).

blood relations, they could have been social-political ties (e.g., De Vaux [1958] 1961, 4-6; Gottwald [1979] 1999, 321-3, 334-7, and see below). Edom, for example, is the "brother" of Israel (e.g., Genesis 25:26, Deuteronomy 2:8). Several Edomite and 'Amaleqite clans, such as Qenaz, Zerah, and Qorah, were also clans in the tribes of Judah, Shime'on, and Benjamin (Genesis 36:5, 12, 18; 1Chronicles 1:35-6, 2:43, 4:15, 25). Qorah emphasizes these relations. He was the son of Esau-Jacob's brother and Edom's father (Genesis 36:14-18); he was a clan of 'Amaleq-Israel's enemy (Exodus 17, etc.), but also a clan of Levy, who served in the tabernacle and in the Temple of Jerusalem (Exodus 6:16-24, 1Chronicles 9:19-34), who also held familial ties with Aaron (Exodus 6:20-25), and to whom 10 Psalms are ascribed (44-49, 84-87). Kaleb, Yerahmi'el, Qenaz Rechab, and 'Otni'el were all desert clans affiliated with Qeni and Edom, who joined the tribe of Judah (e.g., Judges 1:16, 4:11-12, 1Chronicles 2:25-50). Midian was the son of Abraham (Genesis 25:2), whose connections with Moses are well known (Exodus 2-4, 18), who also had familial ties with the Qeni, a tribe of the 'Amaleq federation (Judges $1: 16,4: 11) .{ }^{19}$ In addition, the Israelites are said to have taken 32,000 Midianite women for wives (Numbers 31:9, 18, 35). 'Amaleq was also the ethnic source of the tribe of Ephraim (Judges 5:14). These few examples ${ }^{20}$ with the detailed nature of the genealogical lists, indicate that the complex kinships in Israel were carefully recorded. The very need for detailed genealogy is typical for tribal, egalitarian societies (Gottwald [1979] 1999, 335-7; Faust 2006a, esp. 92-107, and in press; Bailey 2018, 163-72). These lists, therefore, reflect a socio-political reality in which desert clans were actually among the "Proto-Israelites" or joined Israelite tribes. Migration of clans from one tribe to another, and shifts of alliances, are indeed part of tribal reality. A tribe is a rigid social framework 
regarding rules of behavior, but its composition is flexible. ${ }^{21}$ For example, the tribe of Judah gradually formed from desert clans and others, including the Shim'onites (De Vaux [1971] 1978, 546-49; Galil 2001). ${ }^{22}$ The tribal origin of Judah still appears later, in the extensive use of patronyms in the Bible and in epigraphy in the Judaean Kingdom, in $91 \%$ of the names (Golub 2020). This is also found in thousands of Nabataean inscriptions (see below) and among present-day Bedouins.

6. Not only were the names of desert clans common in Israel, geographic names also migrated from the desert to the settled lands. "Reqem" was the old name of Petra (Josephus Flavius, Antiquities 4.7.1); it appears as the city name in a Nabataean inscription at Petra (Starcky 1965), as well as a personal name (CIS II, No. 418). Yet, it was also a town in the land of Benjamin (Joshua 18:17). Qain (Qeni) was not only the name of a desert tribe, but also the name of a town in Judah (Joshua 15:57). "Ir Nahash" ("City of Serpent/Copper") and "Gay' Harashim" ("Valley of Smiths") are identified as the two largest copper smelting camps at the Punon/Feinan area (e.g., Glueck 1970, 98; Aharoni 1979, 36; Levy, Najjar, and Ben-Yosef 2014; Liss et al. 2020) but are also the names of clans in Judah (1Chronicles 4:12, 14). "Mount "Amaleq," in the land of Ephraim (Judges 15:15), is obviously named after the desert tribe from which the tribe of Ephraim actually stemmed (see above). The very name "Har Se'ir" (see below) appears on the border between the territories of Judah and Benjamin (Joshua 15:10). Quite clearly, these names migrated from the desert to the settled lands along with the people, much like places settled by Europeans in North America that were named "New Amsterdam," "New Hampshire," "New England," etc.

7. Compared to all written laws in the Near East, ${ }^{23}$ the biblical law, rendered in Exodus through Deuteronomy, is exceptional. It is highly humanistic, with high morals and a very strict social order (De Vaux [1958] 1961, 143-63; Alt 1966, 81-131; Albright 1968, esp. 157-8). ${ }^{24}$ Such a law system, though unwritten, is typical for tribal, desert societies, for whom social solidarity is imperative for survival in the desert (e.g., Ibn Khaldun 1377:II:§§ 4, 7, 8, 13; De Vaux [1958] 1961, 4-14; Gottwald [1979] 1999, 293-337). Biblical and Bedouin laws are similar in many aspects, for example, the role of elders in judgments, resolving conflicts by mediation, protection of tribe members, revenge laws, and more. ${ }^{25}$ An example of the humanistic nature of the biblical law is evident in the laws of slaves and maidservants, ${ }^{26}$ which all concern their rights. Contrarily, in the Code of Hammurabi, 29 out of 32 slave laws declare the rights of the slave's

21 Ibn Khaldun 1377 II §§12-14; de Vaux ([1958] 1961, 4-15, 19711978, 527-49); Gottwald ([1979] 1999, 293-337); Zevit (2001, 621-6); Na'aman (2005, 253-5). For the complexity of the term "tribe," see, e.g., Zuchman (2009).

22 The tribe of Shim'on was actually formed from desert clans who possessed territories in the Negev before the "Israelite conquest," such as the Negev of Jerahmiel and Negev of Qeni (1Samuel 27:10), Negev of Kaleb (1Samuel 30:1), and Negev of 'Arad (Judges 1:16). The territory of Shim'on was included within the territory of Judah (Joshua 19:1), and later Shim'on gradually assimilated in this tribe (Aharoni 1976, 1979, 260-2; Na'aman 1980).

23 For the Babylonian law, see Driver \& Miles (1952-1955). For a comprehensive collection of laws of the Near East, see Malul (2010). Egypt, however, did not have a written law.

24 See, e.g., Exodus 20, 22; Leviticus 19: Deuteronomy 15.

25 De Vaux (De Vaux [1958] 1961, 152-7); Marx (1967, 63-78, 180-242); Alt (1966, 81-132); Stewart (1988, 2003); Bailey (2018, 107-38).

26 Exodus 20:9-13, 21:2-11, 20, 26-27; Deuteronomy 15:12-18; Leviticus 25:39-55; Jeremiah 34:8-22; King (2009). 
owner or seller, and not one law mentions the rights of the slave himself. ${ }^{27}$ The unique biblical slave laws could stem from the experience of slavery in Egypt (e.g., Leviticus 25:42, 55; Jeremiah 34:13; Averbeck 2016). Indeed, the biblical writers were aware of the uniqueness of their law system (Deuteronomy 4:8). Several scholars argued that at least the "Code of the Covenant" (Exodus 20-24) and the apodictic laws were originally Israelite, established in the desert. ${ }^{28}$ The desert nature of the Israelite law is also echoed in the story of Jethro advising Moses on law issues and social order (Exodus 18:17-27).

8. Cana'anite characteristics in the Israelite religion are well known (e.g., Cross 1973; Smith 1990; Keel and Uehlinger 1992), but significant Egyptian influences on the Israelite religion are also evident, born within Egypt mainly during Akhenaten's rule (second half of the fourteenth century BCE) (e.g., Shupak 2011; Römer 2015, 48-50; Averbeck 2016). The source of this influence could well be Asiatic/proto-Israelite individuals and groups who lived in Egypt during the New-Kingdom. ${ }^{29}$ Egyptian influence on Israel continued during the Israelite monarchy, mainly on the levels of the administrative system and scribe schools (Mettinger 1971; Shupak 1993, and see below).

9. The desert is highly rich in cult sites, especially mașsebot (sing. mașsebah-standing stone), dated from the eleventh millennium BCE to the eleventh century CE. Thousands of prehistoric masssebot have been recorded in the Negev and eastern Sinai, in over 450 prehistoric shrines. Mașsebot are also found in other cult installations and tombs, as well as in hundreds of sites of later periods. Intensive studies of mașebot in the desert and in the rest of the Near East, including radiocarbon dating, showed that their cult originated in the desert and later spread to the fertile zones (Avner 1984, 1993, 2001, 2002, Ch. 4; Avner et al. 2018; Mettinger 1995, 168-74; Hoffmeier 2005, 246-8). Most of the desert mașsebot represented deities (e.g., Avner, above; Mettinger 1995, 140-97; van der Toorn 1997). ${ }^{30}$ Their function was similar to that of divine statues, but they were actually the opposite; the desert mașebot were natural, unshaped stones, representing the gods as imageless abstracts. Thereby, they actually obeyed a theology that was later eloquently phrased in Exodus 20:22: “(...) and if you build for me a stone altar, do not build it of hewn stones, for if you put your chisel upon it you profane it" (emphasis added). According to this perception, altars and the temple itself should be built of "complete stones," untouched by iron tools (Deuteronomy 27:5-6; Joshua 8:30-31; 1Kings 6:7). This principle directly relates to the second commandment (Exodus 20:3), prohibiting the worship of any image. Based on archeological evidence, the non-figurative theology was first born in the prehistoric desert religion and later shared by the Israelite religion, by the Nabataeans (Patrich 1990; Avner 2000) and by Islam (e.g., Sell 1914). What was common to these four religions? Their desert cultural foundation. 278-9, 281-2. See, e.g., electronic text of Cornell University https://upload.wikimedia.org/wikipedia/com mons/f/f7/Code_of_Hammurabi_\%281904\%29.pdf (last visited December 1, 2020).

28 E.g., de Vaux ([1958] 1961, 143-63); Alt (1966, esp. 123-132); Albright (1968, esp. 152, 158-9); Hoffmeier (2005, 181-92).

29 For rich information on Asiatics in Egypt, see, e.g., Helck (1971, esp. 370-431, 446-73, 495-504); Schneider (1992); Hoffmeier (1997, 52-134), and see further below.

30 In the desert, only some mașebot represented ancestors, but in the rest of the world, most standing stones/menhirs represent the ancestors. On the distinction between these two types of masssebot, and references to other standing stones in the world, see Avner (2002, 84-92); Arav et al. (Arav et al. 2016, 18-20 with references). 
Mașsebot in the Bible present a problem, since eighteen passages prohibit their worship. However, a closer look into the biblical sources reveals the following: Twelve of these passages deal with the destruction of masssebot of foreign gods, ${ }^{31}$ and three passages denounce masssebot with no clear deity affiliation (1Kings 14:22; 2Chronicles 14:2, 31:1). One verse prohibits any cult of massebot (Leviticus 21:1) and, surprisingly, only one passage specifically prohibits the cult of massebot for Yhwh (Deuteronomy 16:21), saying: “(...) Do not set up masssebah that Yhwh your God hates" (emphasis added). More so, in all books of the prophets, only two passages condemn the cult of massebot in Israel, Jeremiah 2:27 and Micah 5:12, but conversely, in two other passages, in Isiah and Hosea, masssebot for Yhwh are mentioned in a positive light. Isaiah (19:19) says: "In that day there will be an altar for Yhwh in the Land of Egypt, and a mașsebah for Yhwh within its border" (emphasis added), ${ }^{32}$ and Hosea (3:4-5): "For many days the Israelites will live with no king or a minister, with no sacrifice, no mașsebah and no ephod or trafim. Then the Israelites will return and seek Yhwh their God (...)." Here, the absence of masssebot and other cult symbols is seen as a time of crisis. ${ }^{33}$ In addition to all these, at least eleven other passages mention masssebot with no condemnation at all, and they are all associated with the cult of Yhwh. ${ }^{34}$ An interesting case is the role of massebot in rituals of establishment or renewal of covenants, between individuals (by Jacob and Laban, Genesis 31:45-51), but mainly between Yhwh and the people: by Moses at Mount Sinai (Exodus 24:4), by Joshua at Shechem (Joshua 24:26-7; DeGear 2015), by King Joash in Jerusalem, (2Kings 11:14-20), and by King Josiah also in Jerusalem (2Kings 23:3; 2Chronicles 34:31). The last two kings, according to the Hebrew text, carried out their ceremony "by the pillar" (על (העמוד). In light of the aforementioned verses, the "pillar" is obviously one of the 'neutral' words used by the Deuteronomistic editors of the Bible, instead of mașsebah (others are (אבן, אבנים Making covenants next to mașsebot is also known from Near Eastern texts, most famous is the Sefire Inscription II (Side C, lines 3, 7, 9-10, Fitzmyer 1967, KAI 223), addressing the masssebot on which the treaty texts are written as "House of God" (Aramaic-—בית אלהיא). Kings Joash and Josiah, who both conducted aggressive religious reforms, performed their covenant renewal ceremonies next to mașsebot which they did not destroy. Since Yhwh was a party in these covenants, he was most probably represented by the abstract massebah.

To conclude this point, contrary to the impression that the Bible prohibited massebot, they were legitimate in the cult of Yhwh during the Iron Age, as they are also found in archaeological excavations in Israelite and Judean sites. ${ }^{35}$ How can that be? Both masssebot and Yhwh originated in the desert (for Yhwh, see below). The aniconic masssebah was the natural representation of the invisible Yhwh. Therefore, the mașsebot actually reflect an additional cultural

$31 \quad$ Exodus 34:13, 23:24; Leviticus 26:1; Deuteronomy 7:5, 12:3; 1Kings 14:22; 2Kings 3:2, 10:26-7, 17:10, 23:14; Jeremiah 43:13; Ezekiel 26:11.

32 In most Bible translations, the end of this passage is rendered: "(..) massebah for the Lord on the border of Egypt," leading scholars to see it as a border stone. However, the biblical-Hebrew word " "within," i.e,. "within the territory of Egypt," which the passage also says about the altar of Yhwh. Example for the error see in LaRocca-Pitts $(2001,103)$ and a correction in Avner $(2006,53)$. Problems in translation are common, one additional example is Isaiah 6:13, in which the word mașsebah occurs twice in the Hebrew text, but not at all in the NIV and other translations.

33 In two additional passages Isiah 6:13, Hosea 10:1-2. The attitude towards the mașebot is unclear, probably due to a later Deuteronomistic edition.

34 Genesis 28:16-22, 31:13, 54, 52, 35:14-16; Exodus 24:4-9; Joshua 4:19, 24:36-37; 1Samuel 6:33-35, 7:12; 2Samuel 20:8. The latter is in the high-place of Giveon, where Solomon preformed a large ceremony (1Kings 3:4, 2Chronicles 1:3; 2Kings 3:2, 10:26-27, 11:14-20).

35 E.g., Tell Dan (Biran 1998), Hazor (Becher 2018), Tell Rehov (Mazar 1999), Kh. Qeiyafa (Garfinkel 2018), 'Arad (Aharoni 1968; Bloch-Smith 2015). 
element which originated in the desert and continued to be common in Iron Age Israel. The 'hatred' of mașsebot by Yhwh can be understood as a later development, exilic or post-exilic, reflecting the ideology of the Deuteronomistic editor. ${ }^{36}$

The brief review of the above nine points shows that the desert was indeed profoundly imbedded in the culture, reality, and spirituality of ancient Israel (see de Miroschedji 1933). ${ }^{37}$

\section{The Origin of Yhwh}

In the land of Israel, Yhwh shared characteristics with other Near Eastern gods, but originally, he was different. While all other gods act for and through the kings or the state, "Yhwh acts for and through a whole people (...)" (Gottwald [1979] 1999, 696-7). ${ }^{38}$

Some scholars located the origin of Yhwh in the central or northern Cana'an/Israel, ${ }^{39}$ but most support his southern, desert origin, based on three groups of sources:

1. Biblical passages repeatedly associate Yhwh with Se'ir, Sinai, Edom, Paran, Horeb, Teman (Hebrew for "South"), and Qadesh ${ }^{40}$ (Numbers 10:13,33; Deuteronomy 33:2; Judges 5:4-5; 1Kings 19:8; Habakuk 3:3, Psalms 68:8, 18). All names are in the desert, generally south of Judah. ${ }^{41}$ In addition, Yhwh is related by the biblical writers to the Qenites/Midianites, the desert tribes (see above). Jethro, the Midianite priest and fatherin-law of Moses, led the Israelites' ceremony and sacrificed to Yhwh at the foot of Mount Sinai (Exodus 18:12). In Judges 1:16, he is also mentioned as the father of the Qenites. The Qenites' adherence to Yhwh is also reflected from the position of Rechabites, a Qenite clan. Yehonadab, son of Rechab, was behind the Yhwistic reform of King Yehw

36 For more on the mașsebot in the Bible, see, e.g., Avner (1993, 2001, 2002, Ch. 4, 2006); Mettinger (1995, 43-197); Larocca-Pitts (2001, Ch. 7); Bloch-Smith (2015); DeGear (2015). On mașsebot for Yhwh-see Mettinger (2006, 288-91; Na'aman 2006, 327, 331).

37 Finkelstein (2015) presented a different view, arguing that the desert parts of the biblical narrative were first introduced into the Israelite narrative during the eighth century BCE, when Israel (the northern kingdom) was exposed to the desert through trade with Arabia (see also below).

38 For a variety of aspects of Yhwh (king, warrior, mountain god, storm, sun) see, e.g., Cross (1973); Mettinger (1982, 1988); Van der Toorn (1995); Gerstenberger (1996); Keel and Uehlinger (1992); Klingbeil (1999); Smith (2017), all with references to numerous studies. The solar aspect of Yhwh may relate to the Akhenaten's theology (e.g., Shupak 2011). According to Cross (1962, 150-59, 1973, 60-75) and de Moor (1990, 223-60), Yhwh and 'El were actually the same deity. Smith (2017) showed that Yhwh was originally a warrior god of the desert Shasu, but in the Israelite kingdom his profile absorbed traits of other West Semitic gods.

39 Cross (1962, 252, 1973, 62-63); Astour (1979); Pfeiffer (2017); Müller (2015). Cross argued for an Amorite origin of Yhwh, based on theophoric elements in private names in the Mari Letters and other sources, but this was later refuted by others (e.g., Leuenberger 2017, 163-69). Astour (1979) claimed that the toponym Yhw in Egyptian topographic lists, if indeed referring to the God's name, should be identified in SyriaLebanon, not in the south.

40 For Qadesh instead of qodesh in Deuteronomy 33:2, see, e.g., Axelsson (1987, 49), Ahituv et al. (2012, 30). In many publications the name is spelled "Kadesh," but the true transcription for the Hebrew "P"

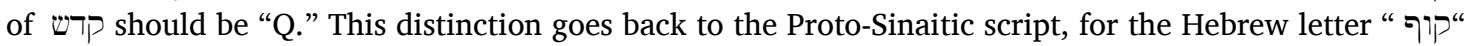
(=monkey?), rolled to "Q" through the ancient Hebrew/Phoenician, Greek, and Latin (see further below). The European "K," on the other hand, developed from Kaf ๆ-Hebrew "hand-palm" (see, e.g., Naveh 1982, 23-27; Goldwasser 2006, 140, 142). This correction should be also applied to Qeni instead of Keni, Qain instead of Cain, and other names.

41 E.g., Weippert (1971, 105, 1974); Axelsson (1987, 48-54); Mettinger (1995, 168, 174); Blenkinsopp (2008, 136-9); Shupak (2011, 99-100); Römer (2015, 40-47); Leuenberger (2017, 173-7). Smith (2017). 


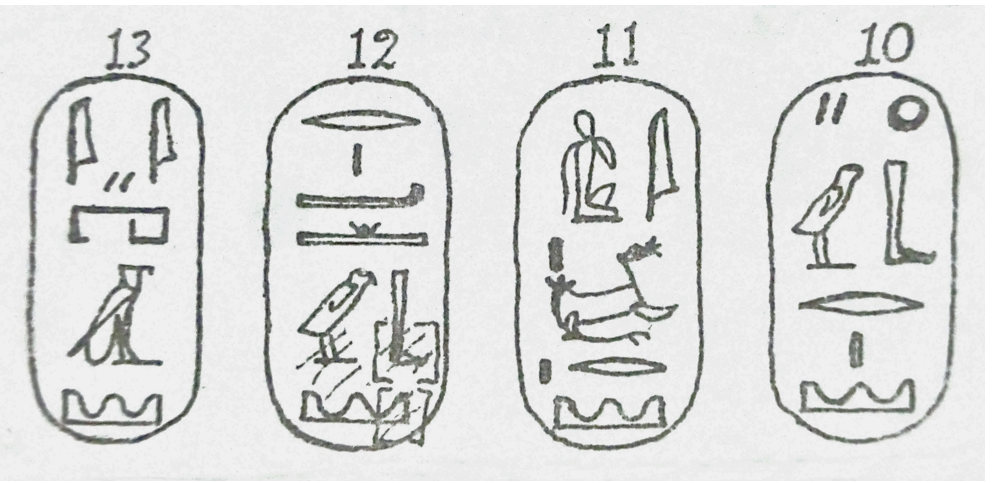

Figure 2 Toponyms of Ramses III from Madinat Habu: 10. Hebron, 11. Rehob, 12. Athar, 13. Yahw (Kitchen 1979, 260, Line 15).

(2Kings 10), and in Jeremiah 35 the Rechabites expressed their desert ideal in connection to Yhwh.

2. Egyptian toponym lists from Soleb, 'Amara West, and Madinat Habu, of Amenhotep III, Ramses II, and Ramses III, respectively, mention names of the Shasu territories (included in longer topographic lists). 'Amara West's list is the most complete, and mentions the names Se'ir, R'b'n' (Laban or Reuben), Psps, Šmt, Yhw, and Trbr (Nos. 92-97). Each toponym is preceded by "the Shasu Land (...)." ${ }^{42}$ Another name appears separately_ "snhs Pwn" or "t3 Shasu Punon" (No. 45). "43 "The Shasu Land Yhw" occurs in the lists of Soleb and "Amara West, while that of Madinat Habu mentions "The Shasu Land Yh". There is a consensus regarding $\mathrm{Yhw} / \mathrm{Yh}$ as a tribal territory where Yhwh was worshiped. ${ }^{44}$ The toponym Yhw also occurs in another topographic list of Ramses III from Madinat Habu, ${ }^{45}$ but is often overlooked. This list renders a sequence of names indicating a road going from Hebron to Athar, Rehob and Yhw (figure 2). In context with the former three names, this Yhw should be located in northern Sinai. ${ }^{46}$

3. The Hebrew inscriptions of Kuntilat 'Ajrud, northeastern Sinai, approx. 800 BCE, mention the name of Yhwh six times, including "Yhwh (of) Teman" ("south") three times, and "Yhwh (of) Shomron" (the capital of the northern Kingdom) once. ${ }^{47}$

Since these three groups of sources have been thoroughly analyzed by many (see Notes 43-46), only three points are highlighted below:

1. The combination and inter-coherence of all these sources strongly attest to the southern

Based on historical and epigraphic details, it has been suggested that the inscriptions of Soleb and 'Amara West follow an older source, earlier in the $18^{\text {th }}$ Dynasty (Giveon 1964, 254-5; Helck 1968, 478; Adrom and Müller 2017, 113).

43 The reading "t3 Š3sw Pwnon" has been offered by M. Görg (1982). It is quoted by several scholars (e.g., Weinfeld 1987, 305), but was not available to me.

44 Grdseloff (1947, 81-82); Giveon (1964, 1967, 1971, 26-28, 74-77, 261-71); Weippert (1971, 105-6, Note 14); Weinfeld (1987); Mettinger (1990, 404-5); Blenkinsopp (2008, 139-40); Leuenberger (2017, 172); Römer (2015, 38-40); Adrom \& Müller (2017, 94-108).

45 Simons (1937, 174, Nos. 10-13); Kitchen (1979, Vol II: 260, Line 15, Nos. 10-13); Krahmalkov (1994, 61).

46 "Athar" relates to-_דים דרד האתרים "the road of Atharim" (Numbers 21:1), through which the Israelites entered the Negev from Qadesh Barne'a. Rehob may be identified with Rehobot, the later Nabataean-Byzantine town in the northwest Negev (Tsafrir 1988). E.g., Hadley (2000, 120-36); Zevit (2001, 370-81); Ahituv et al. (2012). 
origin of Yhwh, as agreed by most scholars.

2. In the Egyptian inscriptions from 'Amara West and Madinat Habu, the desert sections of the lists open with "the Shasu land Se'ir" (in the Soleb list, the first toponyms were not preserved). Therefore, Se 'ir seems to be a general title for the following toponyms. ${ }^{48}$ This implies that Se'ir was a large area, encompassing several tribal territories. In the Bible, Se'ir appears as a synonym of Edom, but sometimes it indicates a distinctive region (see a detailed analysis of the sources in Bartlett 1969). Edom is usually identified as the mountainous area east of the 'Arabah, while Se'ir is identified by some as the desert to the west, i.e., the Negev and at least parts of Sinai. ${ }^{49}$ However, this allocation is not definite. In the view of biblical writers, the Negev was an Edomite territory (Joshua 15:1, 21), as far west as Qadesh Barne'a (Numbers 20:16, see Grdseloff 1947, 73-74), and as far south as Elot (Eilat) and Ezion Geber on the Red Sea (1Kings 9:26). ${ }^{50}$ Several scholars see the Land of Se'ir as a region encompassing both sides of the 'Arabah. ${ }^{51}$ The location of some of the toponyms from the three groups of sources may also illuminate the extent of Se'ir. Teman is usually identified with Edom, the mountains east of the 'Arabah Valley, ${ }^{52}$ and Punon is identified with Faynan in the northeastern 'Arabah, in Jordan, at the foot of the Edomite Mountains. ${ }^{53}$ Paran should be identified in southern Sinai, approx. $300 \mathrm{~km}$ southwest of Punon as the crow flies (see below).

We may conclude from this brief survey that Se'ir was indeed a large area that included the Edomite Mountains, the Negev, and Sinai as one geographical unit, divided into a number of tribal Shasu territories. This view accords with the plural Akkadian term "the lands of Se'ir" (“KUR.HAL.A Se“iri / matati Se'iri,” El-‘Amarna Letter 288:26, Rainey 2015, 116-17). ${ }^{54}$

3. Several scholars have suggested different locations for the "Shasu land Yhw," where the God was probably worshiped: in the Edomite Mountains (Redford 1992, 273; Blenkinsopp 2008), in northern or northwestern Sinai (B. Mazar 1981; Ahituv 1984, 121-2), ${ }^{55}$ the southern Negev and eastern Sinai (Mettinger 1988, 24-28, 1990, 408), and the 'Arabah Valley (Hoffmeier 2005, 242; Leuenberger 2017, 171-2). Since Yhwh is associated in the three sources with Midian, Se'ir, Edom, Teman, Punon, Qadesh, and Paran

48 See Weippert (1974, 265-80, 427-33); Weinfeld (1987, 305); Römer (2015, 39); Adrom \& Müller (2017, 99, Note 39).

49 Glueck (1968, 44-45, 173-4); Bartlett (1969, 1989, 41-46); Weippert (1971, 105); Axelsson (1987, 4, 59); Ahituv (1984, 169); Weinfeld (1987, 304). Redford (1992, 273); Edelman (1995, 3).

50 This view might reflect the situation of the seventh to sixth centuries BCE, when Edomites penetrated and settled in the northern Negev (Beit-Arieh 1995, 1996). However, according to Na'aman (1992, 74, 2015, 203), "Edom" of the Books of Kings actually refers to the "Arabah and the Negev Highlands.

51 Grdseloff (1947, 73-74, 80); Na'aman (1992, 74); Goedicke (1994, 24-25); Lipinski (2006, 363); Vassiliev (2006, 163).

52 'Amos 1:11-12; Glueck (1972); Bartlett (1989, 33-37, etc.); Ahituv et al. (2012, 96, 130); Weinfeld (1987, 305).

53 Glueck (1968, 44-45, 1970, 34); Aharoni (1979, 36, 204, 245); Bartlett (1989, 50); Hauptmann (2007, 39, and see below). Since there is no "P," in "Arabic, in many place names the Hebrew "P" has been replaced by Arabic "F" or "B."

54 I'm thankful to Wayne Horowitz, who confirmed, upon my request, that translation of the Sumerian logograms do indicate the plural, "the lands of Se'ir."

55 Vassiliev (2006) pointed to a specific land of the "Shasu, n3 tswt," in the sand dune region of northern Sinai, but did not identify it with the "Shasu Land Yhwh." 
(see above), he was probably worshiped in most of the greater Se'ir (see Weinfeld 1987, 306; Axelsson 1987, 57-58). ${ }^{56}$

The southern connection of Yhwh is actually the heart of the "Qenite-Midianite Hypothesis," seeing Israel and its God emerging from the desert (e.g., Blenkinsopp 2008; Leuenberger 2017; Tebes 2017; Na'aman 2016). The present paper supports the thesis of a southern origin of Yhwh, with additional materials underutilized in published discussions, but sees the origin of Israel as a more complex process.

\section{Possible Occurrences of Yhwh in Other Egyptian Sources}

In a copy of a spell from the Egyptian Book of the Dead, dated to the $18^{\text {th }}$ and $19^{\text {th }}$ Dynasties, Schneider (2008) identified the private name "Adoni-Roa'e-Yah," Hebrew for "My lord (is) the shepherd of Yah," or "Adonai Ro'i Yah" i.e. "My Lord (is) my shepherd". According to Schneider, the deceased that carried the spell was most probably a foreigner, acculturated into the Egyptian elite. Yah is quite certainly the abbreviation of Yhwh (e.g., Exodus 15:2; Psalms 94:12), the name אדניהו "My Lord Yahw" is well known in the Bible as King David's son (1Kings 1, 2; 2Chronicles 17:8), and the title "הוה רעי "Yhwh (is) my shepherd" is also known (Psalms 23:1). Other passages also describe Yhwh as a shepherd (e.g., Jeremiah 23:1-6; Isiah 40:1, Ezkiel 34). If Schneider's reading is accepted, this is the earliest presently known private name bearing the theophoric element "Yah." 57

An earlier occurrence of Yhwh may appear on a stela from Thebes, of the $11^{\text {th }}$ Dynasty (late third millennium BCE), published by Gardiner (1917, 35-39). The text, a 'report' to an unknown king, includes the following: “(...) I (Akhthoy) brought to him (to the king) the best of the foreign lands in new metal (or copper) of Ba'et, shining metal (or copper) of Ihuiu, hard metal of Menka'u; in turquoise of Hrerwotet (...)" Since the name Ihuiu appears with the determinative of "foreign land," it should denote a territory, much like Yhw in the topographic lists of the New Kingdom. The relation between the metal/copper of Ihuiu and the land of Bi3w / Bia' brought Gardiner to suggest its location in southwest Sinai, since the name occurs on several stelae from the temple of Serbit al-Khadem, within this region (Gardiner 1917, 36; Gardiner, Peet, and Çerny 1955, 1-2; Stelae Nos. 53, 90, 117, 141, see Hoffmeier 2012, 109) (see also figures 3 and 11). Gardiner did not make a connection between Ihuiu and Yhw, rather, this was suggested by Weippert (1971, 105-6, Note 41). The name may be pronounced Ihiu / Ahiu (Weippert 1971, 105-6, Note 41) or Ahu (Astour 1979, Note 10).

Identification of Yhwh in the last two sources has been accepted by some scholars ${ }^{58}$ but rejected by most others due to a different orthography. ${ }^{59}$ Nevertheless, several points may

56 Yhwh was not the only west Semitic God-name in this region. At Serabit al-Khadem, in southwest Sinai, $\mathrm{Ba}^{\prime} \mathrm{al}$ occurs as a theophoric element in the personal name 'Apar-Ba'al (Gardiner et al. 1955, Stela No. 423), and Shalem occurs in another name, "Shalem-Shama' " (Giveon 1981, and see below). El occurs in a ProtoSinaitic inscriptions at the same site (Beit-Arieh 1985, Pl. VIII:18, fig. 15:10, 1987, 59). Inscription 385 from Serabit al-Khadem has been read by Cross (1962, 238-40) and by Albright (1969, 24, fig 9) as 'l d-'lm ("eternal El"), but corrected by Sass (1988. 29-30) to 'd d-'Im ("for ever"). Nevertheless, the occurrence of $\mathrm{El}$ as a theophoric element in desert clans and private names (Otniel, Jerahmiel, Re'uel, Eliphaz) attest to his early worship in the desert. According to Cross (1973, 60-75), Mettinger (1990, 395-409) and others, Yhwh was a cultic name or epithet of El, so they were actually one.

57 Schneider's reading has been denied by Adrom \& Müller (2017, 108-9, 111-13).

58 Giveon (1964, 244, 1971, 27); Axelsson (1987, 60); Geodicke (1994, 26).

59 Ward (1972, 58); Astour (1979, 18); Ahituv (1984, 122, Note 295); Adrom \& Müller (2017, 94-103); Kennedy (2019, 188). 
support Gardiner's reading and Weippert's interpretation. One is that orthography of names often changes in transliteration, in our case, a Semitic name written in Egyptian hieroglyphs (see, e.g., Shesha', below). Second, the region of southwest Sinai was the major source of turquoise for the Egyptians, ${ }^{60}$ which Akhtoy mentioned several times in his inscription. In addition, the same area is also rich in copper ores, exploited from the early Egyptian dynasties through the New Kingdom, but mainly during the Middle Kingdom (Gardiner, Peet, and Çerny 1955, 3-7; Tallet, Castel, and Fluzin 2011; Abdel-Motalib et al. 2012). Third, one aspect of Yhwh relates to copper smelting (Jasmin 2018; Amzallag 2019, with references to his previous papers on this topic $)^{61}$. Hence, the "shining metal/copper of Ihuiu" makes sense. Fourth is the role of "Asiatics" ('3mw) in both the turquoise mining and the copper industry in the same region (see below).

If the above reading and interpretation are accepted, they may indicate a very early occurrence of the name of Yhwh, and his earliest link with Sinai.

\section{Asiatics in Southwest Sinai and the Proto-Sinaitic Script}

Several Egyptian stelae at Serabit al-Khadem, dated to 1800 to 1500 BCE, mention Asiatic persons. ${ }^{62}$ Some stelae (Nos. 85, 110, 114, 120) mention 10 and 20 unnamed Asiatics, probably simple workers; Stela 110 mentions 20 men from Hami, identified with Hormah in the Negev. ${ }^{63}$ Other stelae mention Asiatics by name, in low numbers, indicating they were foremen or professionals. An Asiatic noble, "Khebded, brother of the prince of Retenu," is mentioned on four stelae (Petrie 1906, 118; Černy 1935, figs. 2-5; Gardiner, Peet, and Çerny 1955, Nos. 85, 87, 92, 112). On Stela 112, he is also depicted riding on an ass and escorted by a man and a child. Similar depictions occur on Stelae 103, 115, and 405, without mentioning his name. On the latter, he is shown carrying a 'duckbill' axe while the two escorting persons are armed with spears. Remains of yellow, red, black and white paint on the stela indicate his prestigious garment. His role was most probably overseeing the Asiatic workers and negotiating with the Egyptians. ${ }^{64}$ An impressive stela, of genuine Egyptian style, bears the Asiatic name: 'Shalem-Shama', "(the god) Shalem heard” (Giveon 1981). ${ }^{65}$ Obelisk 163

60 Petrie (1906); Gardiner (1955); Giveon (1978); Tallet (2012).

61 Several papers by Amzallag address the metallurgic aspect of Yhwh, based on biblical references (e.g., Numbers 21:9; Kings 18:4; Isaiah 31:9; 45:3; 54:16; Ezekiel 1:27, 10, 22:19-22, 40:3; Zechariah 6:1-5, 13:9) and on additional data. In relation to the Exodus narrative, Yhwh is mentioned as 'refining' his people in the desert as the smith refining metal in an iron furnace (Deuteronomy 4:20, 1Kings 8:51, Jeremiah 11:4; McNutt 1994, 123-4). It is also worth mentioning that "copper" (נחושת) and related terms are mentioned 199 times in the Old Testament, while in later sources (NT and Jewish sages) only a few times. On metallurgy in Jewish sources, see Leven \& Rothenberg (2007). One comment is needed here. In Amzallag's publications, Yhwh is titled a Cana'anite God, but he was not (see, e.g., Gottwald [1979] 1999, 696-7; Müller 2015, 35-38; Leuenberger 2017, 164-5).

62 Černy (1935); Gardiner (1955, Stelae Nos. 24a, 81, 85, 93, 85, 98, 110, 112, 114, 115, 117, 120, 123b, 163, 405); Helck (1971, 82-83).

63 Numbers 21:2-3, Deuteronomy 1:44, Joshua 12:14, Judges 1:17 etc. Hormah is identified in several sites in the northern Negev: at Tel Malhata (Mazar 1965, 229-31), Tell Masos (Aharoni 1979, 201, 215-16; Ahituv 1984, 113-14), and Tell Halif (Na'aman 1980, 142-3).

64 "Brother" means a feudal allegiance to a master here (Giveon 1978, 132). Seemingly, riding on an ass is low-esteemed, but in the ancient world it signified dignity (Stadelmann 2006). For the position of Hebded and his possible connection with the inventors of the Proto-Sinaitic script, see Goldwasser (2014). For the popularity of the element "Shalem" in Judaean private names, see Golub (2015). 
belongs to three brothers, one is Qeni (Keni), ${ }^{66}$ so most probably they were Qenite tribesmen. A high official with an Egyptian name, "Amnisoshenen... the Asiatic," owned seven stelae (Nos. 93-99, Gardiner, Peet, and Çerny 1955, 100-106). Stela 423 was dedicated by "AperBa'al (Gardiner, Peet, and Çerny 1955, 212). A number of stelae (e.g., 86, 105, 412) bear the name Hor/Hori, which, according to Kitchen $(1998,88)$, is also Semitic, appearing 15 times in the Bible (Exodus 17:10, 12, 24:14 etc.), but possibly of Egyptian origin (Muchiki 1999, 211).

Stela 81 mentions a scribe named Rua/Lua, (Černy 1935, 384; Gardiner, Peet, and Çerny $1955,90)$, equated by Giveon $(1978,134)$ with the biblical name Levi. ${ }^{67}$ This stela is of interest to this study for several reasons. First, Lua was not the only known Asiatic scribe mentioned in Egyptian inscriptions. Stela 123b at Serabit al-Khadem belonged to "the judge, chief lector priest, priest and scribe, the Asiatic Werkherephemut" (Gardiner, Peet, and Çerny 1955, 128; Giveon 1978, 157). Other Asiatic scribes are known from Egypt. An Asiatic scribe named Rafi left a small stela at Qantir/Avaris (Kitchen 1998, 89, with references). Dedia was the Asiatic scribe of Seti I (Alon and Navratilova 2017, Ch. 7). Hori (see above) was the name of the Asiatic author of the "Satirical Letter" Anastasi I, with a deep knowledge of Cana'an. (ANET 475-9; Alon and Navratilova 2017, Ch. 9). He also bore the title $m h r$ (Anastasi I, 18:36) Hebrew for "swift" or "intelligent" (see סופר מהיר, Psalms 45:2; Ezra 7:6). Still another scribe's name, "עזרממ" ('Oz-Romem), is possibly mentioned in a Proto-Sinaitic inscription from Timna' (Wimmer 2018). ${ }^{68}$

Second, finding Asiatic scribes in Egypt should not be taken for granted. Learning the Egyptian language, reading and writing hieroglyphic texts, with approx. 700 signs and additional complexities, was a difficult task that required talent and long training. Scribe students in Egypt had to begin their learning in childhood, under a harsh discipline and high demands; they had to be knowledgeable in many fields, including mathematics. When they finally became scribes, they gained a high social status and promotion opportunities (Williams 1973). In this light, it is remarkable that Asiatics could become official Egyptian scribes.

Third, the scribe's name on Stela 81, Lua, probably Levi, is specifically interesting. Levites and priests later mentioned in the Bible bear Egyptian names (Hophni, Pinḥas ${ }^{69}$, Pashhur and others) and attest to the service of Levites and Asiatic priests in Egypt (see Ahituv 1970; Hoffmeier 1997, 223-34, 2016, 18-31; Muchiki 1999, 221, 222, 224). An important example of an Asiatic with such a career is "Ben-Azan/Adon" (Hebrew, "Son of a Lord"). He was brought from Cana'an to Egypt as a child in the time of Merenptah, educated to be a "priest of pure hands," and was given the Egyptian name Ramsesemper'. He later rose to a high position in the court of Ramses III and left behind nine stelae. One of his accomplishments was the resumption of Egyptian involvement in the copper production at Timna' after a break of some 20 years (Schulman 1976; Avner 2014, 140). The scribe on Stela 81, named Lua/Levi from Serabit al-Khadem, recalls several Levite scribes who are later mentioned in the Bible (1Chronicles 24:6, 2Chronicles 34:13). Qeni on Stela 163 is also interesting, since four Qenite

66 Petrie (1906, 118, fig. 121); Černy (1935, 385); Gardiner (1955, 147, No.163).

67 The title "scribe" is not attached to Lua, but "possessor of honor," a title that regularly attached to scribes, just like the other scribes mentioned on the same stela and on many others.

68 There is some doubt as to the authenticity of the inscription, but Wimmer's discussion $(2018$, 7) does support its value. Colless (2010) also takes the inscription as authentic but renders a different reading.

69 Interestingly enough, a King's scribe named Pinhasy is mentioned on Stelae 211, 217, and 219 to 222 at Serabit al-Khadem, but his name indicates that he was "Negro" (Gardiner, Peet, and Çerny 1955, 168) or Nubian (Muchiki 1999, 222). 
families of scribes also appear in the Bible (1Chronicles 2:55). Another scribe affiliated with the Qenites was Ye'uel (2Chronicles 26:11), a member of Zerah (1Chronicles 9:6), an Edomite clan (Genesis 36:13, 17) related to Qeni, to Midian, and to Moses (Numbers 10:29; Judges 4:11). An additional family of scribes included Shia' (שיא) / שישא / Shesha' / Shausha' ( שושא), the scribe of King David (2Samuel 20:25, 1Kings 4:3, 1Chronicle 18:16 respectively), and his sons Elihoref and Ahiyah were the scribes of Solomon (1Kings 4:3). The father's name is Egyptian, stemming from the title sš- "scribe" (Gardiner, Peet, and Çerny 1955, 18-19 etc.; Mettinger 1971, 25-30; Muchiki 1999, 226; Shupak 1993, 350).

Altogether, we see here an accumulation of data on Asiatic scribes from Middle Bronze Sinai, probably from the Late Bronze Timna', and then from the Iron Age Bible. Many of them had desert roots and tight connections to Egypt. The timespan of these data may seem too long to bear any relevance, but as we know from Egypt and from Shia', Elihoref, and Ahiyah in the Bible, the scribes often perpetuated their profession within their families, from one generation to another (Williams 1973). Such a theoretical continuous scribal tradition may explain the Egyptian influence on the scribe schools in Iron Age Israel (Mettinger 1971, Ch. 10; Shupak 1993, esp. 347-54). Indeed, according to Muchiki (1999, 324), the roots of this influence (many Egyptian names and loanwords in Hebrew) can be traced back to the Middle Kingdom.

The 44 Proto-Sinaitic inscriptions from southwest Sinai (Serabit al-Khadem, Wadi Nașib, and Wadi Magharah) are important fingerprints left by the Asiatics. ${ }^{70}$ The idea behind this script was revolutionary, selecting a small number of pictograms to form a simple, acrophonic script. Most letters were adopted from the Egyptian hieroglyphs of the Middle Kingdom, around $1840 \mathrm{BCE},{ }^{71}$ but were vocalized differently, fitted to Semitic speech. The question is, who were the Asiatics behind this invention? Egyptian inscriptions at Serabit al-Khadem state that they originated from Retenu, a term usually applied to Cana'an, but also to the broader Levant (Redford 1992, 200). Helck (1971, 266-7) went further to show that the term Retenu was originally applied to Se'ir. According to Petrie $(1906,118)$, the Asiatics at Serabit al-Khadem came from southern Palestine and from Sinai, while Gardiner $(1916,14)$ and Černy (Černy 1935, 389) emphasized Sinai as their province. Darnell (Darnell et al. 2005, 88, 91) ascribed the invention of the script to Asiatic mercenaries in the Egyptian army, while Giveon $(1978,143)$ suggested that these Asiatics came to southwest Sinai from Egypt. This could be true of those who bear Egyptian names. Goldwasser (e.g., 2014, 363, 371) sees them as Cana'anites, but also as "desert experts." Most scholars saw these Asiatics as intelligent and skilled persons who developed their capabilities through tight contacts with the Egyptian culture and through exposure to hieroglyphic monuments. ${ }^{72}$

From the data gathered here it seems that the Asiatics in southwest Sinai were mainly the inhabitants of the greater Se'ir, i.e., the desert people; for them the desert was not hostile and their knowledge of its environment was most valuable. Learned Asiatics, like Lua/Levi, Qeni,

$70 \quad$ E.g., Gardiner (1916); Albright (1966); Sass (1988, 2006); Goldwasser (2006, 2010, 2017); Petrovic (2016).

71 A later date was preferred in the past, around 1500 BCE (Albright 1966; Naveh 1982, 25-27; Beit-Arieh 1985), or even around 1300 BCE (Sass 2006). However, the Middle Kingdom date, as first suggested by Gardiner (1916, 13), is now followed by most scholars, e.g., Darnell et al. (2005, esp. 86-92, 102); Hamilton (2006, 289-303); Goldwasser (2017, 190) and Petrovich (2016, 6-12, 188-91).

72 Gardiner $(1916,11)$, Naveh $(1982,42)$ and Millard $(2012,15)$ argued that they were learned, skilled Asiatics. According to Hamilton $(2006,294)$ they were "at least somewhat literate." Goldwasser, on the other hand (2010, 43-44, 2011, 267-73, 2017, 190-91), based on paleographic analysis, views the inventors of the script as illiterate Cana'anites who could not read the hieroglyphs. A reply to Goldwasser can be found in Colless (2014, 79). 
and Werkherephemut, could well be among those who invented the first alphabetic writing in the world. Their language was quite close to the biblical Hebrew, with similar personal names and terms (e.g., Albright 1969, 38-45; Sass 1988, 220-22), or may even have been proper biblical Hebrew (Petrovich 2016, esp. 6-13, 186-200). ${ }^{73}$ These Asiatics may have also been one source for the wealth of Egyptian idioms included in the biblical narrative (Shupak 1993, 2011; Hoffmeier 2016; Hess 2016; Noonan 2016; Averbeck 2016) and the source of Egyptian influence on the Israelite scribe schools during the monarchy period (see above).

Besides mining turquoise in southwest Sinai, the Asiatics were also strongly affiliated with the intensive copper industry. This includes the large pile of copper slag at Bir Nasib (approx. 150x250 m, figure 3), and smaller smelting sites have been described by Petrie (1906, 18, 51-52) and by Gardiner et al. (1955, 3-7, 30-31); over 3000 furnaces (!), arranged in long batteries, were discovered by Tallet et al. (2011) on the hills above Wadi Nașib. The copper mines in the region were re-surveyed by Abdel-Motalib et al. (2012, 12-15), who added new sites and data. The furnace batteries are attributed to the Egyptians, mainly of the Middle Kingdom, but no signs of Egyptians were found around the copper mines (see Gardiner, Peet, and Çerny 1955, 7), implying that they were operated by Asiatics. Copper workshops found in Mines G and L at Serabit al-Khadem were also employed by Asiatics (Beit-Arieh 1985, 1987), who left 17 Proto-Sinaitic inscriptions in and around them (Sass 1988, Table 1).

\section{The Shasu and Copper Industry}

During the New Kingdom, the Asiatics were termed "Shasu" by the Egyptians and were mentioned in some 50 Egyptian texts. The word means "wanderers," those who "move on foot," or "herders."74 They were described indeed as shepherds living in tents, warriors, enemies of Egypt, captives taken by Amenhotep II and III, Seti I, Ramses II and III, but also as mercenaries incorporated in the Egyptian army. During years of droughts they were sometimes permitted to enter into the eastern Delta with their herds for water and pasture ${ }^{75}$ some Shasu were depicted as nobles. ${ }^{76}$ Geographically, as noted above, they were mainly mentioned within Se'ir, Edom and northern Sinai, but also within Egypt, and even reaching Syria and Lebanon. The Shasu were not a marginal minority. The list of captives taken by Amenhotep II in his nineth year campaign to Cana'an (1444 BCE) included 36,000 Haru (Cana'anites), 3600 'Abiru, 15,200 Shasu, and others (ANET 247; Helck 1971, 486-7). Due to their lifestyle, they were often equated with the "Patriarchs" of the book of Genesis and with early Israel. ${ }^{77}$

73 The Proto-Sinaitic script later developed into ancient Hebrew and Phoenician, then to Greek and Latin, eventually to present day European scripts; it also developed to Aramaic, Nabataean, and 'Arabic. Today, several billion people in the Near East, the entire Western world and beyond, are using this desert invention without being aware of it (e.g., Sass 1991).

74 Giveon (1967, 195, 1971, 261-4); Helck (1968); Redford (1992, 271); Lipinski (2006, 361); Hoffmeier (2005, 240).

75 Grdseloff (1947); Giveon (1967, 1971); Helck (1971, 274-5); Weippert (1974); A.W. Ward (1972); Redford (1990, 68-78, 1992, 269-80); Ahituv (1999); Vassiliev (2006); Rainey (2008a); Hoffmeier (2005, 240-43, 2016); Leuenberger (2017, 169-72); Papyrus Anastasi VI:4.11-6.5 (Gardiner 1937, 76-77; Caminos 1954, 293-5).

76 These are depicted on colored, glazed tiles from Madinat Habu (Giveon 1971, Pl. 13; A. F. Rainey 2008a, photo in P. 53) with no reference. Redmount $(2001,118,611)$ gave credit to Jürgen Liepe, Berlin, with no further information.

For a different opinion, separating the Shasu from Israel, see Stager (1985). 


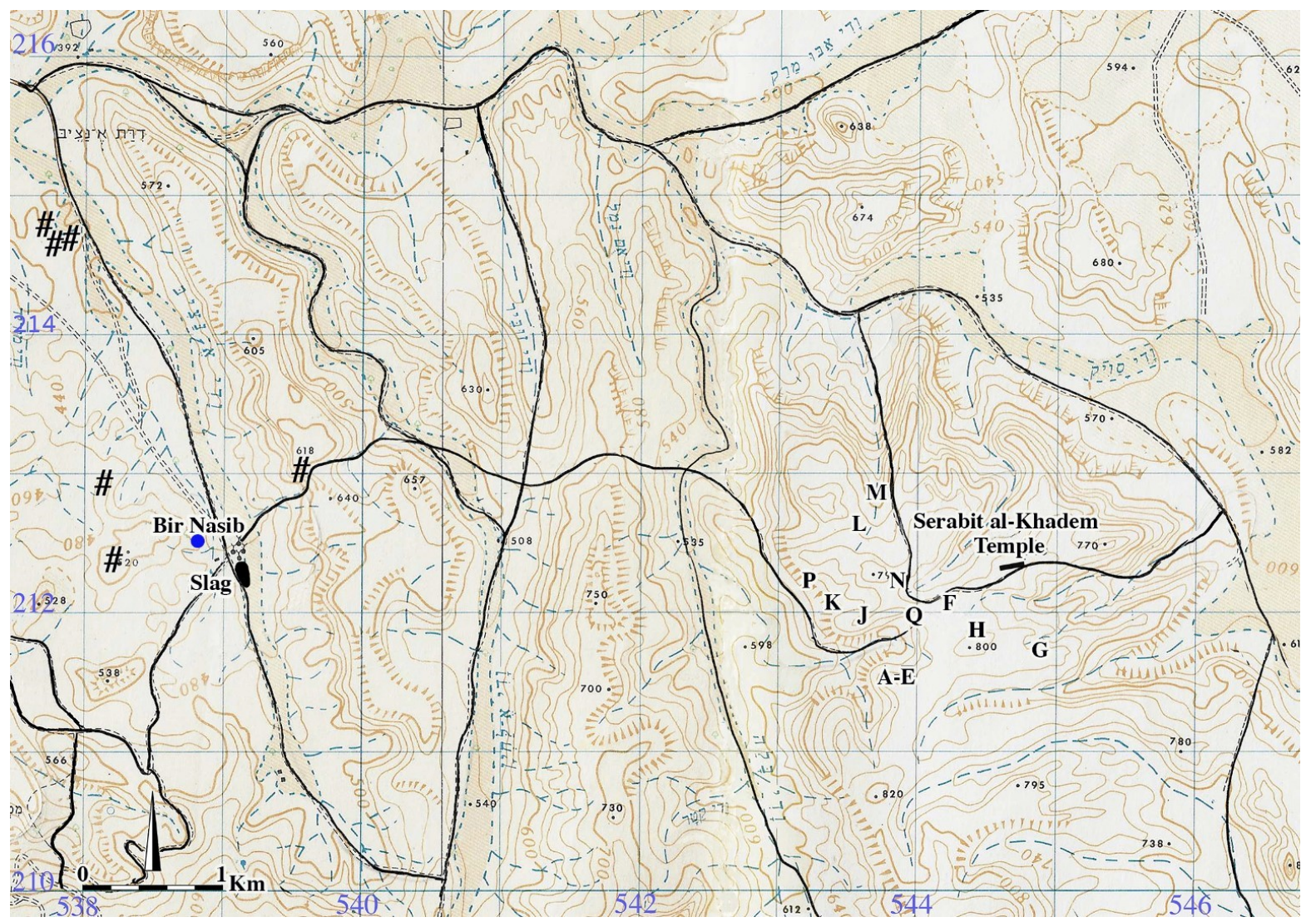

Figure 3 UTM map of Serabit al-Khadem and Wadi Nasib area, showing the main ancient trails, the location of the temple, the turquoise mines (F-N), Egyptian rock stela and inscriptions (AE), and rock shrine (Q) after Petrie (1906, 55). Dark spot next to Bir Nasib: the copper slag pile and \#- furnace batteries, after Tallet's maps (2011, 80, 85; 2012, 153), which show many more mines, copper production sites, and inscriptions. 
Since they were thoroughly discussed by scholars (Notes $43-46,74,75$ ), only a few issues are addressed here:

Affiliation of the Shasu with the copper industry creates increasing interest, especially in the 'Arabah Valley, which is rich with copper deposits (figure 4). Following the studies of Rothenberg at Timna' (e.g., 1972, 1988, 1999a, 1999b), the Late Bronze-Iron Age copper mining and production was accepted by many as the outcome of Egyptian initiatives, control, and technology. However, new studies show a different scenario. The southern 'Arabah was indeed conquered by Ramses II (approx. 1280 BCE), and was occupied (with an interruption of 20 years) until the time of Ramses V (approx. 1150 BCE; Schulman 1988, 145). Many Egyptian artifacts were discovered in the miners' sanctuary at Timna' (Rothenberg 1988), but the actual role of the Egyptians in the industry was limited. The sanctuary, in fact, belonged to the local desert tribes, whom the Egyptians joined. Hathor was not the owner of the sanctuary but only a guest of the local gods. The technology of mining and smelting, as well as the organization of the work, were all in the hands of the desert people (Avner 2014). None of the other copper mining centers along the 'Arabah, Nahal 'Amram (Avner et al. 2018), and Faynan (Punon) showed any signs of New Kingdom Egyptian control or presence. ${ }^{78}$ More so, many tens of radiocarbon dates from these three centers and from smaller smelting sites along the 'Arabah prove that the tenth century BCE was the heyday of the copper industry, 150 to 250 years after the last Egyptian presence at Timna' ${ }^{79}$ Copper production and trade on such an enormous scale required thousands of workers, sophisticated skills, complex logistics, and a high level of organization. ${ }^{80}$ Seemingly, the only potential power to administrate such an industry at that time was the United Monarchy of Israel (David and Solomon); however, no sign of the kingdom's presence was found in the copper mining and production centers along the 'Arabah. Judaean pottery, which is common in contemporary sites in the Negev Highlands (Cohen and Cohen-Amin 2004, esp. 121-141), is absent in all these copper centers. Hence, the only other remaining candidates to control this immense industry were the desert inhabitants, the Shasu. ${ }^{81}$ In addition, the huge cemetery at Faynan (Fidan 40), where 287 tombs were excavated (out of approx. 7000), is attributed to the Edomite Shasu, based on the site's context, on the grave goods, mortuary practices, the cemetery's egalitarian nature and the absence of nearby contemporary stone-built habitations (Levy, Adams, and Muniz 2004; Levy 2009; Beherec, Najjar, and Levy 2014; Beherec et al. 2016). It is even suggested that the organization of the Shasu around the copper industry brought them to a level of "tribal kingdom" (BenYosef 2019) which was actually the base for the rise of the Edomite Kingdom (e.g., Levy, Adams, and Muniz 2004). Because of the great importance of the 'Arabah as a copper source, and due to the Shasu domination of the metal industry, one of the suggested identifications of the "Shasu land Yhw" is in this very region (Hoffmeier 2005, 242; Leuenberger 2017, 171-2).

Another point may connect the Shasu with the "Arabah copper industry. In excavations of Timna' Site 34, six colored tassels were found (figure 5) (Ben-Yosef 2016, Fig. 10; Sukenik et al. 2017). In several presentations of Shasu in Egyptian reliefs and paintings, they were depicted as warriors, armed with bows and arrows and wearing tasseled kilts. Giveon (1971,

$78 \quad$ A number of small Egyptian scarabs and amulets were found in the Iron Age Faynan cemetery (Münger and Levy 2014), mainly dated around 1000 BCE, much later than the end of Egyptian presence in Timna'. These were personal objects of the deceased, which were identified as Shasu.

79 Levy et al. (2014, Ch. 2); Avner (2014, Table 1); Avner et al. (2018, Table 1); Ben Yosef (2016, 2018).

80 Levy et al. (2004); Avner (2014), Avner et al. (2018); Ben-Yosef (2018, 2019).

81 Levy et al. (2004); Levy (2009); Avner (2014, 141-4); Avner et al. (2018, 172); Ben-Yosef (2019 and in press). 


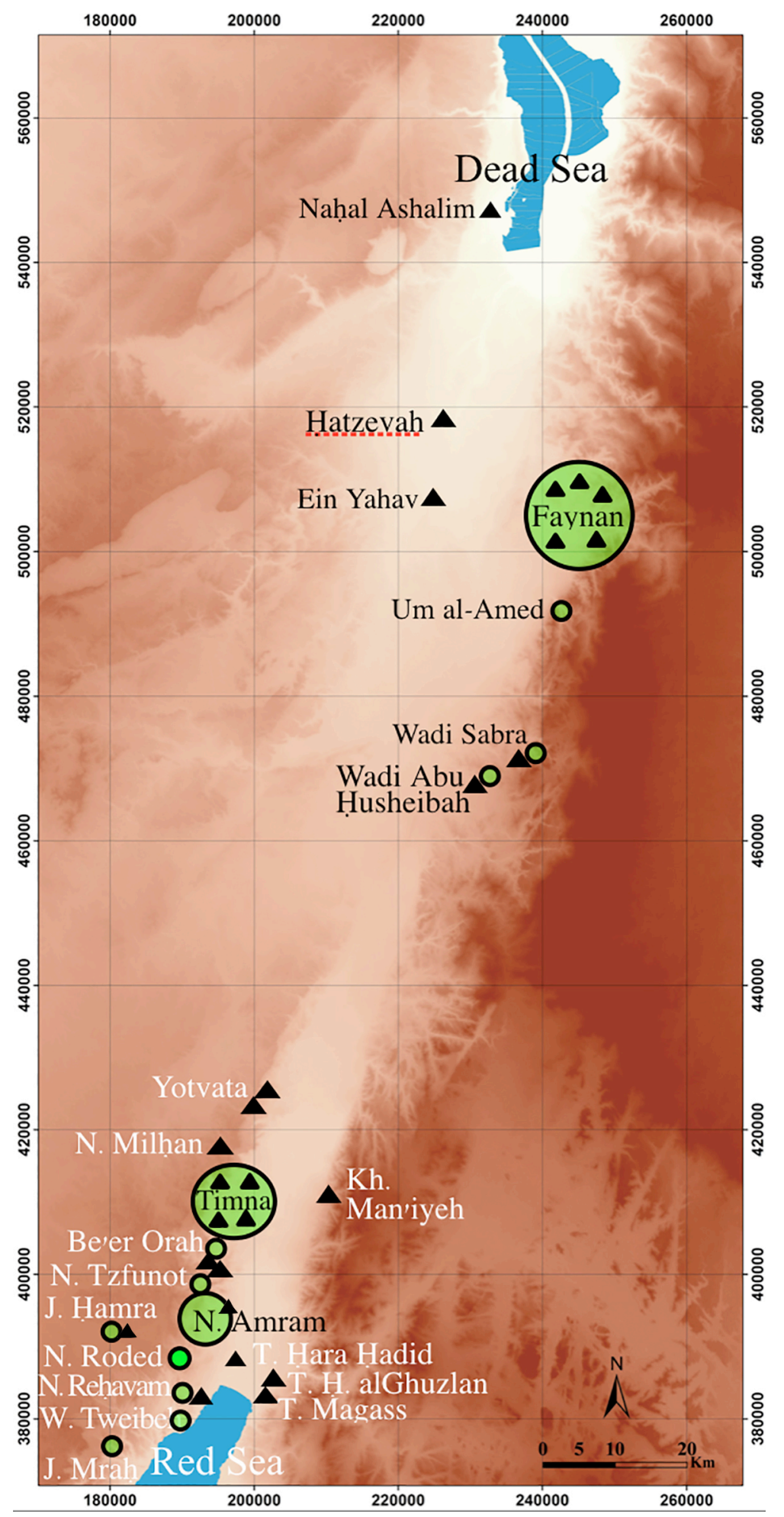

Figure 4 Map of the 'Arabah copper mines and production sites, from Chalcolithic to Early Islamic periods. Green spots indicate copper mines, black triangles are smelting centers. 


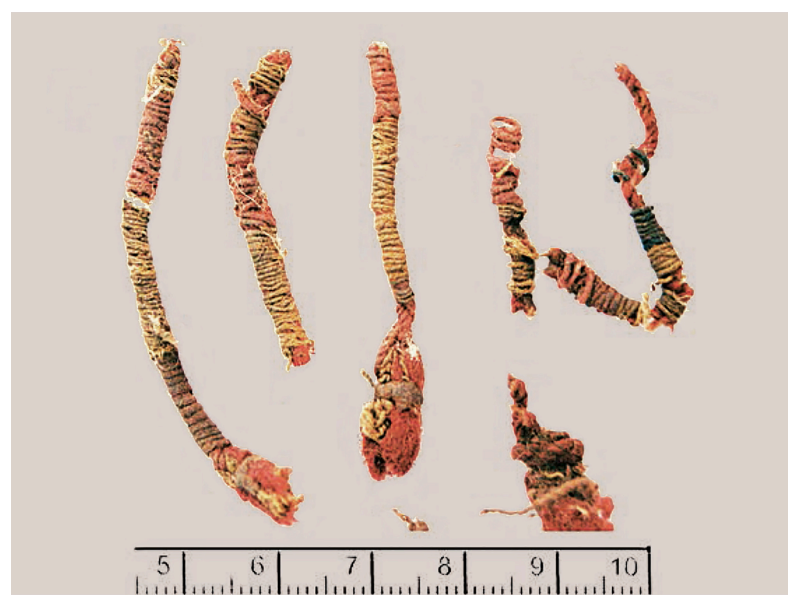

Figure 5 Dyed tassels from Timna' Site 34 (Ben-Yosef 2016, 179).

241, Pls. II, III) equated these tassels with the biblical ones (ציציות) that the Israelites were instructed to wear (Numbers 15:38-9; Deuteronomy 22:12; Shamir 2014), and that Jewish observants still wear today. Tasseled garments were also worn by others in the Near East, mainly by gods and nobles (Bertman 1961), but Giveon's suggestion may be valid in light of another discovery from Timna'. To date, 19 prestigious textile fragments were found in Site 34, dyed red and blue (figure 6); similar fragments were also found in Site 30 and in the miners' sanctuary (Site 200, Sukenik et al. 2017 with references). These recall the "blue and scarlet" textiles (תכלת וארגמן) mentioned 28 times in the book of Exodus, relating to the tabernacle's fabric sheets (e.g., 26:1,31,36; 27:16) and to the priests' garments (e.g., 28:8, 33; 39:1). ${ }^{82}$ This is likely an additional link between the Shasu, the large-scale copper industry, and possible biblical-Israelite customs. The presence of prestige textile at Timna' links with the Egyptian depiction of Shasu nobles wearing fancy garments (Note 76), with the prestige garment of Hebded at Serabit al-Khadem (see above), with further finds from Timna' indicating the rich diet of the copper smites (Sapir-Hen, Lernau, and Ben-Yosef 2018), and with parallel finds from the Nahal 'Amram mines indicating the high quality diet of copper miners in later periods (Avner et al. 2018).

Additional finds from Timna' may associate the Shasu with Israel. In smelting Site 30, Conrad and Rothenberg (1980, 205-8, Beilage 27) excavated a building from Phase I, dated by them to the thirteenth century BCE, partially covered by a slag pile date by a series of ${ }^{14} \mathrm{C}$ dates approx. 1050 to 900 BCE (Ben-Yosef et al. 2012, 55-62). The building consists of an elongated courtyard containing a silo and a grinding stone, flanked by two aligned pairs of rooms on each side. The walls separating the courtyard from the rooms are built of alternating monoliths and fieldstones (figure 7). The masonry characteristics and the ground plan recall those of the renown Israelite "four-room house." The perpendicular backroom, typical for this type of house, seems missing here, but a southwestern corner, slightly exposed by the excava-

82 There is one important difference between the biblical blue and scarlet and the finds from Timna. The dyes of the former are made of shellfish (Hexaplex trunculus, Murex Brandaris and Thais Haemastoma), while the latter, addressed here, are made of plants (Rubia tinctoria L. and Isatis tinctoria L.). The finds from Timna are actually the earliest known textiles in the Near East to be dyed by plants. For details, see Sukenik et al. (2017); Workman et al. (2017). For the priest garment, see Shamir (2014, 2017). An important addition, recently published (January 2021), identifies the true indigo purple from Timna Site 34 (Sukenik et al. 2021). This is the earliest find of the kind in the southern Levant and it bears further indication for the elite involvement in the desert copper industry. 


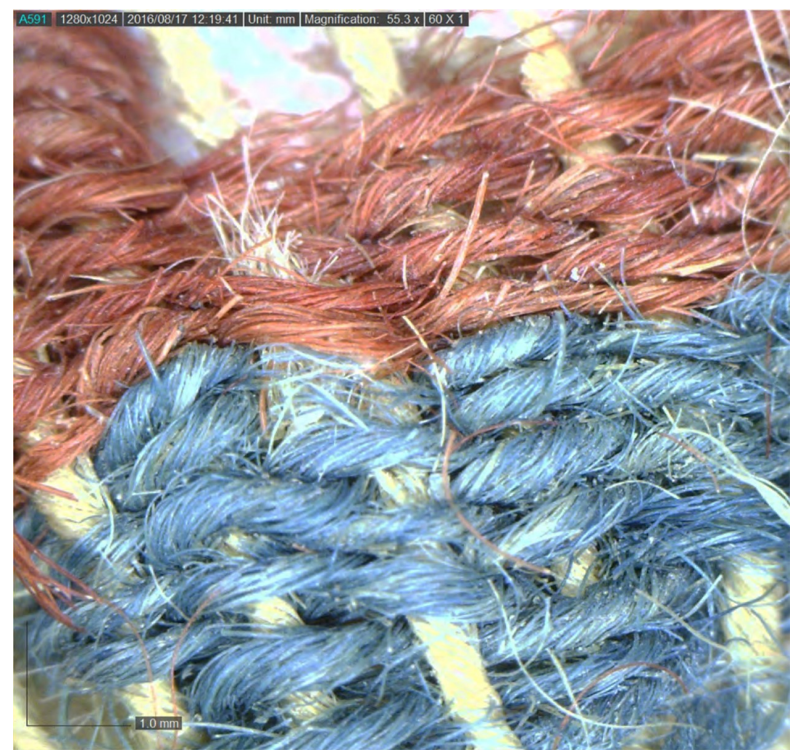

Figure 6 Blue and scarlet textile from Timna' 34 (Sukenik et al. 2017, 17).

tors (but not reported) hints at its existence. ${ }^{83}$ A larger building resembles "four-room house" (approx. 12x12 m), discovered in 'Uvda Valley, $20 \mathrm{~km}$ northwest of Timna' 30, situated among a scatter of tens of tent camps, and belonged to an agro-pastoral population (figure 8) (Avner 1979, 18). Finds from the surface and from a small probe included pottery sherds of the same three types known at Timna' (wheel-made, hand-made Negebite, and decorated Midianite). This building most probably served public functions for the population, similarly to a later Nabataean public building in the same area, also built in the middle of a large cluster of tent camps (Avner 2019, 606-8, fig. 29). As discussed above, the best candidate for the population of Timna', as well as of 'Uvda Valley, is the Shasu. "Four-room houses" discovered at Thebes, Egypt, were also attributed to Shasu workers, "closely related to the Proto-Israelites" (Bietak 2015, 18-21).

The central Shasu group in the copper industry seems to be the Qenites, discussed in a number of studies. ${ }^{84}$ Qain (Cain), their ancestor, is mentioned as the first copper and iron smith (Genesis 4:22; 1Chronicles. 4:13-14). He was cursed by God to be a "wanderer" (עי רנד, Genesis 4:11-12), the exact parallel to the Egyptian term "Shasu." 85 The Qenites' affiliation to copper production seems to have a long history. The names Qeni already occurred at Serabit alKhadem in the early second millennium BCE (see above), and later occurred as Qini/Qinu/Ibnal-Qini in tens of Nabataean inscriptions in the same area of southwest Sinai (see below). Still

83 For the "four-room house," see, e.g., Shiloh (1970), Netzer (1992); Faust \& Bunimovitz (2003). For the alternating monoliths and fieldstone masonry in four-room houses and in fortresses, see 'A. Mazar (1981a, Fig. 2, Pl.42, 1981b, Figs. 3, 9, 11); Fritz \& Kempinski (1983, II, Taf. 12, 13); Cohen \& Cohen-Amin (2004, figs. 15, 24, 39). For a silo or other installations in the court's backside see, e.g., Fritz and Kempinski (1983, II, Plans 18, 19). There is no difficulty in the fact that the building does not fully resemble the 'mature' four-room house, since this appeared only in the tenth century BCE (Iron Age II), with the establishment of the United Monarchy, while during the twelfth to eleventh centuries (Iron Age I) the many variations of the house indicate a long process of consolidation (Faust in press).

84 E.g., Glueck (1940); Albright (1963); B. Mazar (1965); de Vaux (1969); Halpern (1992); McNutt (1994); Day (2009); Blenkinsopp (2008, 140-45).

85 On the ambivalent nature of Qain and of smiths in traditional societies, see e.g., McNutt (1994, 120). In short, the smith is a magician, semi-divine, but also socially marginal, bearing "Qain's Mark" (to protect him, Genesis 4:15). 


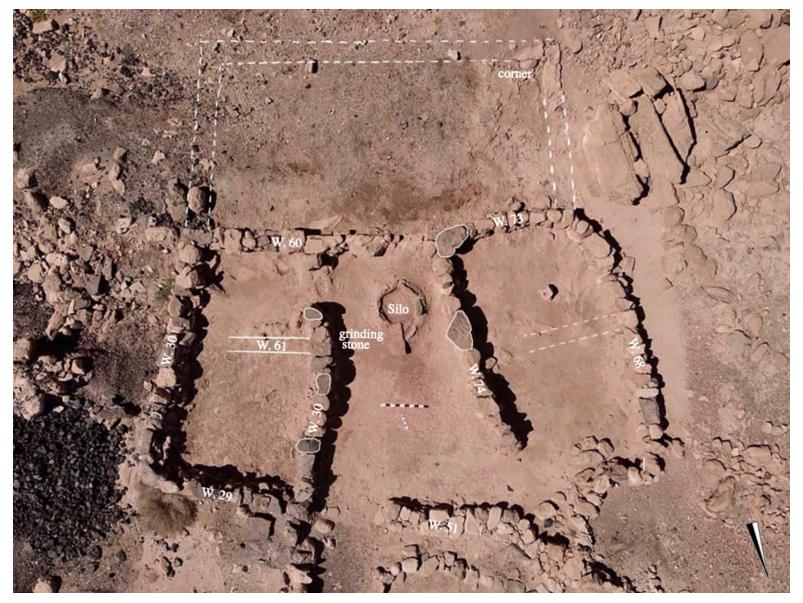

Figure 7 Timna' Site 30, a building similar to the "four-room house," excavated by Conrad \& Rothenberg (see 1980, Beil. 27). Monoliths are indicated by white outlines, Wall 61, now missing, solid white line, missing partition wall in the right wing follows remains shown in Beil 27, conjectured walls of the backroom are based on the exposed corner. Scale: $1 \mathrm{~m}$.

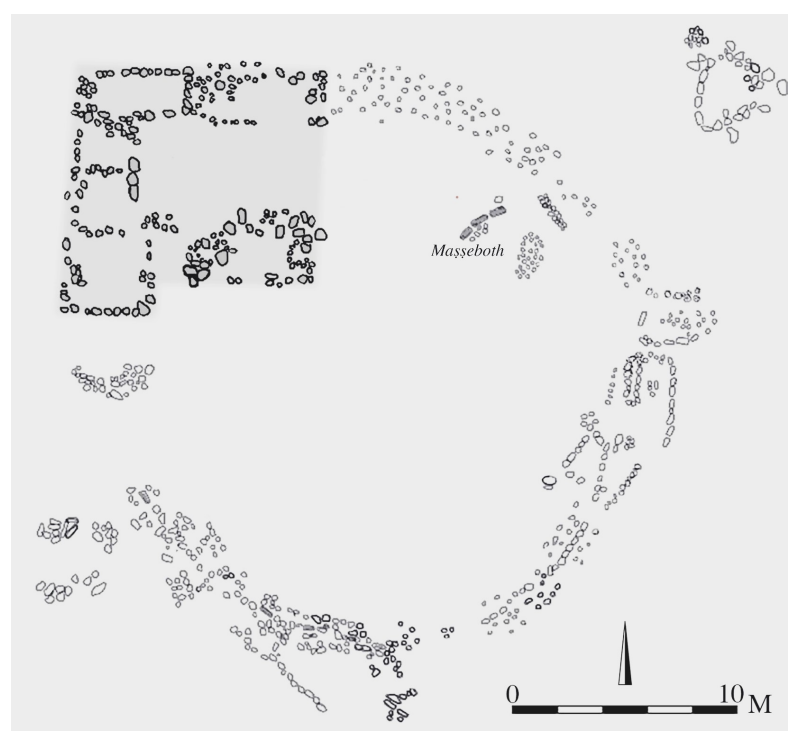

Figure 8 'Uvda Vally Site 53c, a "four-room house" (highlighted grey) built on top of large courtyard of the fifth to third millennia BCE. 
later, the Jewish tribe of metal smiths, Qainuqa (Kinuka), lived in the Northern Hijaz (Midian) until the Time of Mohammad (Wensinck 1978). All these variations of the name stem from the Hebrew root קנה, which means "create" and "smith." ${ }^{\text {" }} 6$ The smith appeared as a magician, turning rocks into metal and 'creating' a new substance. ${ }^{87}$

Pertinent to this scenario is the distribution of the "Negebite" and "Midianite" pottery. The former contains crushed copper slag as a temper (Yahalom-Mack et al. 2015; Martin et al. 2013) and is therefore certainly locally made, in the Negev, in northeastern Sinai and Southern Jordan. The latter was produced in Qurayya in northern Hejaz, ca. $150 \mathrm{~km}$ southeast of 'Aqaba, found in copper production centers along the 'Araba and in other sites as far north as Gezer. Both types indicate that Qenites, Midianites, and other Shasu groups were involved in the copper industry, while the Midianite pottery also attests to international trade of copper and of 'Arabian exotic goods (Rothenberg and Glass 1983; Brandle 1984; Jasmin 2006; Tebes 2006, 2017; J. Tebes 2007a, 2007b). Indeed, copper from the 'Araba was spread during the Iron Age to several destinations in Cana'an/Israel (Yahalom-Mack et al. 2014; Yahalom-Mack and Segal 2010, 2011) as well as to Egypt (Vaelske and Bode 2019).

Finding the Qeni in the Sinai inscription, the Qenite connection with the copper industry, their alliance with Israel, and joining the tribe of Judah (e.g., Judges 1:16, 4:11, 1Samuel 15:6) brings us a step closer to the "Midianite-Qenite Hypothesis." ${ }^{8}$

\section{The Geographical Connection of Kuntilat 'Ajrud}

The Hebrew inscriptions and drawings of Kuntilat 'Ajrud have been analyzed in many publications ${ }^{89}$. Here, we only mention the recurrence of the name Yhwh in the inscriptions: three times associated with Teman, once with Shomron (the capital of the northern kingdom) and twice with no geographic association. Other gods are mentioned too: Asherah, four times (with Yhwh), El twice, and Ba'al once (Ahituv, Eshel, and Meshel 2012).

The site's location requires specific attention. Kuntilat 'Ajrud is built on the top of an isolated hill in northeast Sinai, $50 \mathrm{~km}$ south of Qadesh Barne'a. According to Meshel (1978, 2-6, $21,1983,52)$, it is located next to a junction of three roads: One is Darb Ghaza, ${ }^{90}$ an important trade route connecting the Mediterranean ports with the Gulf of Eilat, identified by Meshel (1981) with the biblical דרך ים סוף ("The Red Sea Road"). Second is a road leading to southern Sinai, and third is a road crossing Sinai from east to west. Based on this location, on architectural remains and finds, Meshel suggested two functions of the site: a trade station on the way to the Red Sea, and a religious center. With time, Meshel (e.g., 2012, 3-4, 65-69) concentrated on the religious nature of the site in light of the inscriptions and drawings, but still connected it to Darb Ghaza and to Eilat. Subsequently, several scholars emphasized the

86 Genesis. 14:19, 22 אל עליון קונה שמים וארץ ("God most high, creator of heaven and earth”) and the same title in three different inscriptions (KAI \# 26, Donner, Röllig, and Röllig 1968, 1:42; Hoffner 1965; Avigad 1972, 195-6).

87 Forbes (1950, 62-69); Eliade (1956, 1978, 52-55); Gošič \& Gilead (2015); McNutt (1994).

88 The above scenario, connecting the Qenites with the 'Arabah's copper sources and with Yhwh, was suggested by Grdseloff $(1947,79-83)$ long before the presently accumulating archaeological data on the copper industry in the region.

89 E.g., Hadley (2000); Zevit (2001, 370-405); Keel \& Uehlinger (1992, 210-48); Ahituv et al. (2012) ; Beck (2012); Na'aman (2013); Ornan (2016).

90 Often erroneously written "Darb al-Ghaza." 
function of the sites as a road-station, serving Israel's international commerce with 'Arabia and Africa, through Eilat. ${ }^{91}$

This view, however, requires a correction. The road map of the area is actually more complex, as can be seen on "Newcomb Map" of the Negev (figure 9). Since the map was prepared before the introduction of motor vehicles into the desert (in 1913/14 by the British Intelligence, published in 1921 by the Palestine Exploration Fund), it reliably represents the desert network of ancient-traditional roads. ${ }^{92}$ According to this map, the junction of Darb Ghaza and the road crossing Sinai from east to west is not near Kuntillet 'Ajrud, but at Kossaima, northwest of Qadesh Barne'a. The road on which Kuntillet 'Ajrud is actually situated branches off Darb Gaza $13 \mathrm{~km}$ north of the site, and is $15 \mathrm{~km}$ west of the Darb Gaza (figure 9) (see Meshel 2012, 3 and Fig. 1.1). Therefore, Kuntillet 'Ajrud is not connected at all to Darb Ghaza and does not control it. If indeed the site were associated with Darb Ghaza and with trade, it would have been built on this very road, for example, on the hill just southwest of the important water well of Kuntilah (figures 9, 10, 11), $34 \mathrm{~km}$ southeast of Kuntilat 'Ajrud. Passing through Qadesh Barne'a to Eilat via the road on which Kuntilat 'Ajrud is truly situated would add two unnecessary days to a caravan journey. More so, the most efficient route for caravans from Jerusalem or from Shomron to Eilat or Ezion Geber is not through Darb Ghaza but through the 'Arabah Valley. This route was well defined by Burckhardt $(1822,443)$, who described an eight-day camel ride from Hebron to "Aqaba through the "Arabah: "(...) for this is both the nearest and the most commodious route, and it was by this valley that the treasures of Ophir were probably transferred to warehouses of Solomon" (in Jerusalem). In addition, along the 'Arabah there are many more water sources and more pasture for the camels. Compared to Burckhardt's trip, Robinson and Smith's camel ride $(1856,173)$ from 'Aqaba to Hebron, through Darb Ghaza, required ten days. ${ }^{93}$

The true destination of the road running through Qadesh Barne'a and Kuntilat 'Ajrud was southern Sinai and is presently named Darb Sha'ira, after a mountain's name further south (figure 11). Based on geography and similarity of the names, Ilan (1970) suggested this road may be identified as the biblical דרך הר שעיר (the "Mount Se'ir Road"). The name is certainly interesting in its biblical context, following Deuteronomy 1:1-2: “(...) in the 'Arabah-opposite Suph, between Paran and Tophel, Laban, Hazeroth and Di-Zahab. It takes eleven days to go from Horeb to Qadesh Barne'a by the Mount Se'ir Road." Scholars commonly agree that Qadesh Barne'a is located at 'Ein Qudeirat (e.g., Hoffmeier 2005, 122-4; Cohen and BernickGreenberg 2007, 4, both with references), an important oasis with a running stream (figure 12), while the biblical name, Qadesh, has been preserved in another spring named 'Ein Qadis, $8 \mathrm{~km}$ to the southeast. An Iron Age fortress with four main strata has been excavated at 'Ein

91 E.g., Hadley (2000); Lipinski (2006, 373); Finkelstein (2013, 21-25 and Fig. 1, 2014, 101 and Fig. 1); Niehr (2013) and see more references to this position in Strawn and LeMon (2018, Note 11). Meshel (2012, 3-4, 65-69) was aware that the site is situated west of Darb Ghaza, but still maintained that from this post, the kings of Israel (i.e., Shomron) controlled the international trade on Darb Ghaza. Niehr (2013) supported the trade function based on the presence of Phoenician script and language at Kuntilat 'Ajrud. Na'aman (2013, 43-44), however, noted that not one Phoenician name was found at the site, but added arguments opposing the trade hypothesis.

92 A survey of ancient roads in the Negev and eastern Sinai, assisted by the Newcomb Map, showed that flint items and pottery sherds covering the last 10,000 years are found on most trails. Hundreds of prehistoric cult sites that attend these roads indicate the that the entire network of the desert road was already well established in the early Neolithic period (Avner 1984, 2002, Chs. 4-6, 2016, 2019, 609-12; Avner et al. 2018).

For a detailed discussion on the 'Arabah Road, see Avner (2016, 2019, 609-12). 


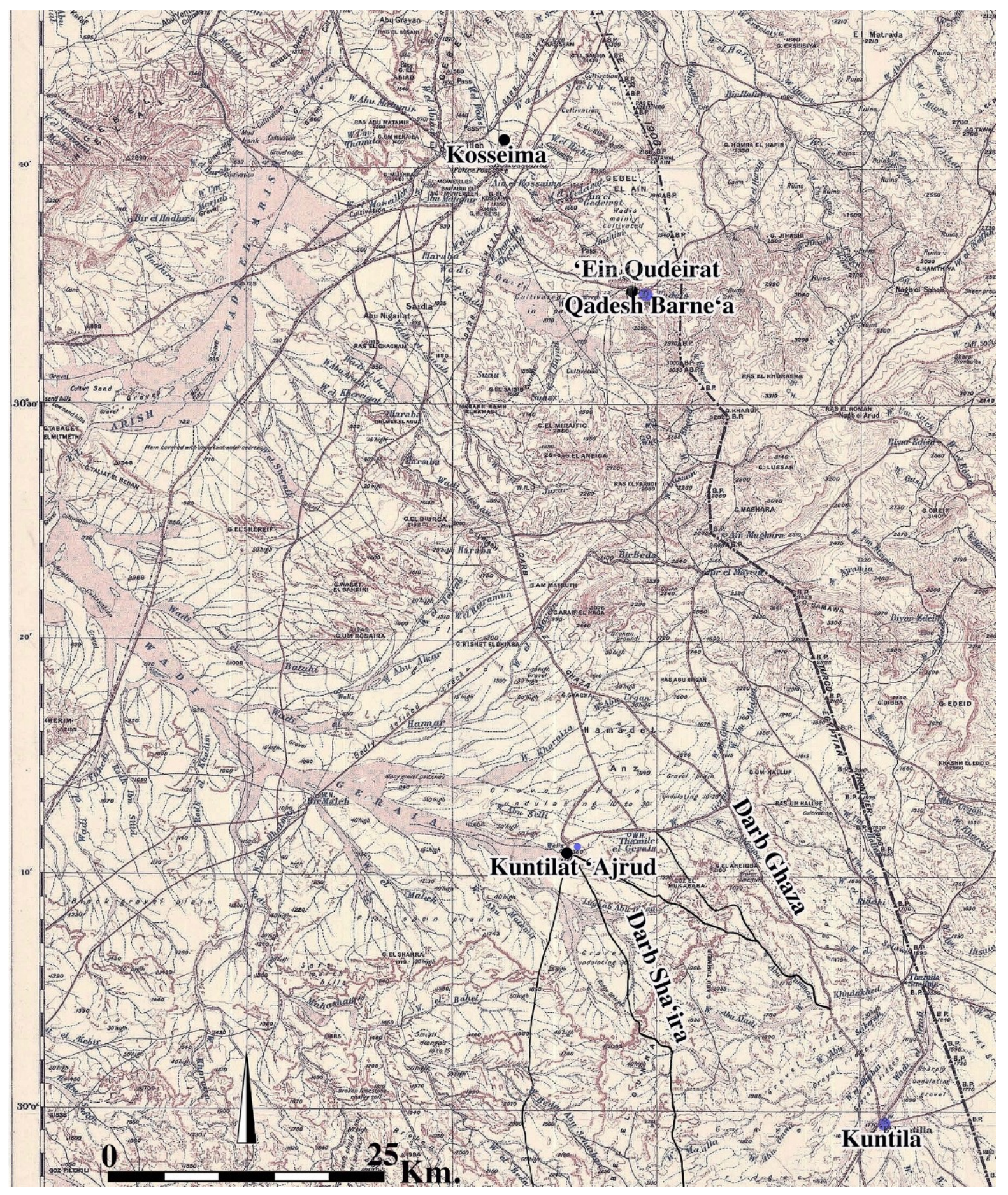

Figure 9 A section of the Newcomb Map (1914) showing the (ancient) road network around Kuntilat 'Ajrud. 


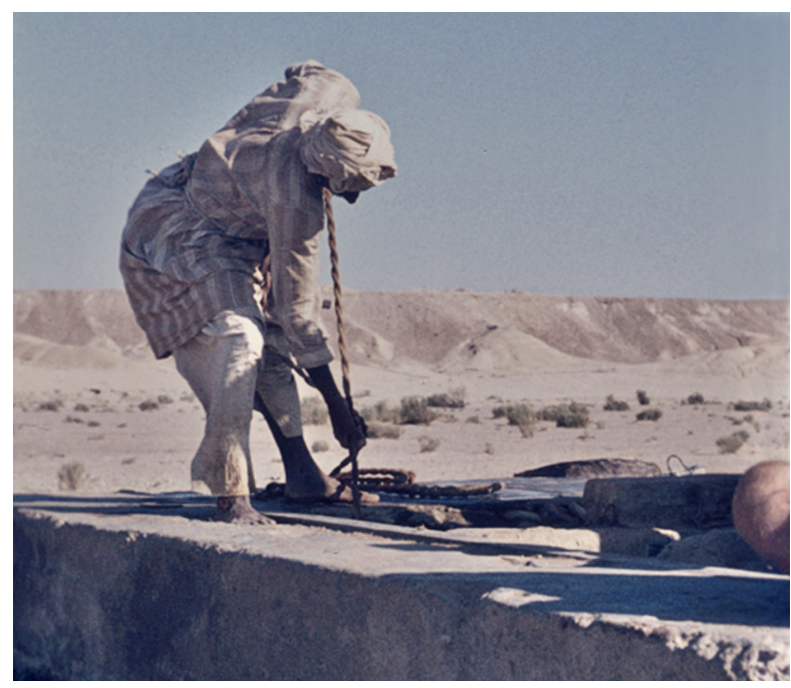

Figure 10 The well of Kuntila, on Darb Ghaza.

Qudeirat (Cohen and Bernick-Greenberg 2007). The lowest (Stratum 4) is a small rounded "fortress" or "enclosed settlement" 94 dated by radiocarbon from the late thirteenth to the early ninth centuries BCE. ${ }^{95}$ This is the period of the Exodus, the Judges, and the United Kingdom. In sum, Darb Sha'ira runs from Qadesh Baene'a through Kuntilat 'Ajrud and the foot of Jebel Sha'ira southward to southern Sinai. This connection is also illuminated by eight pieces of sycamore and Pistacia wood found in the site which originated in southern Sinai (Liphschitz 2012, 345). The significance of this point is addressed in the next paragraphs.

\section{The "Desert of Paran" and "Mount Paran"}

One of the puzzles in reconstructing the geography of Se'ir is locating the "Desert of Paran" (Genesis 21:21, Numbers 10:12, etc.) and "Mount Paran" (Deuteronomy 33:1-2), a synonym of Mount Sinai/Mount Horeb. Today, "Nahal Paran" is known as the largest wadi in the Negev, a name used by Anati (e.g., 2001, 47-54) as one argument supporting his identification of Mount Sinai with Har Karkom, west of Nahal Paran. However, this name was given to the wadi by the "National Committee of Names," nominated in 1949 by the young Israeli government in order to replace older "Arabic names with Hebrew ones. In this case, the Bedouin name "Wadi Jirafi" was converted to "Nahal Paran," on no historiographic ground. ${ }^{96}$

The real Paran must be searched for in the igneous mountain region of southern Sinai. Much of this region is drained by the great Wadi Feiran, which includes the largest oasis in the peninsula, a five-kilometer long palm grove (figure 13), and a Nabataean-Byzantine town

94 Many of the Iron Age fortresses of the Negev Highlands are circular or oval, with casement walls or a complete series of rooms on their perimeter. These sites are under debate, interpreted as either Israelite fortresses or settlements of the desert inhabitants. For references to both, see Faust (2006b)

95 Five ${ }^{14} \mathrm{C}$ dates from the lower fortress were published by Carmi \& Segal, in Cohen and Bernick-Greenberg (2007, 304), ranging from the eighteenth to the fourth century BCE, which means that the organic remains in this stratum were mixed. One charcoal sample from the destruction level of this lower stratum was taken by Bruins and Van der Plicht (2007, 488, 491)-GrN-12330, $2930 \pm 30$ BP, re-calibrated by myself with OxCal 4.3- 1220-1025 BCE (95.4\% probability). However, fourteen ${ }^{14} \mathrm{C}$ dates from this stratum presented and discussed by Gilboa et al. (2009) date it to the Iron Age IIA, around 1000 BCE.

96 The choice of the name Paran for Wadi Jirafi has been decided by the Comity, forwarded by B.Z. Eshel, Y. Ben-Zvi and A.Y. Brover (Protocol No. 8, October 20, 1949) and published in Reshimon 1951:3 (Hebrew). 


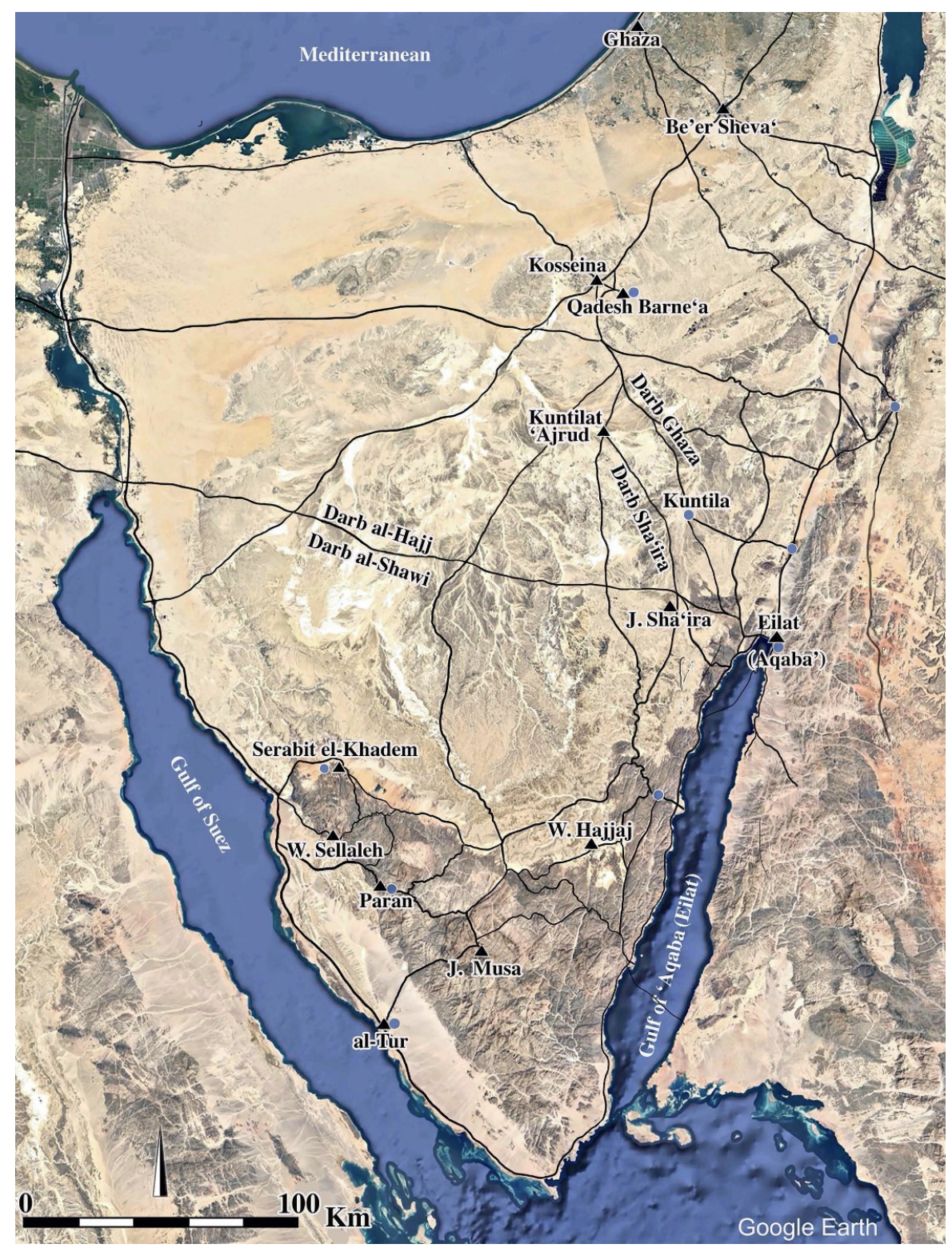

Figure 11 Map of the Negev and Sinai, showing the sites mentioned in the text and the main ancient roads.

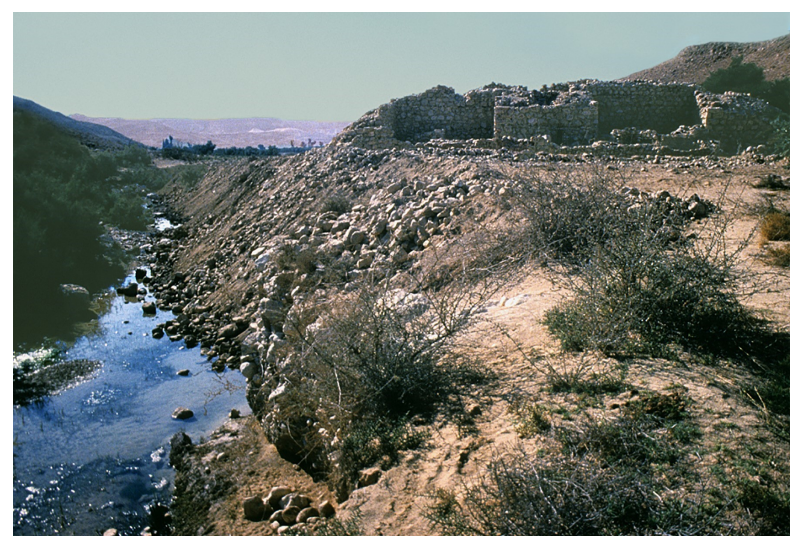

Figure 12 'Ein Qudeirat Oasis, identified as Qadesh Barne`a, with a running stream and the Iron Age fortress. 


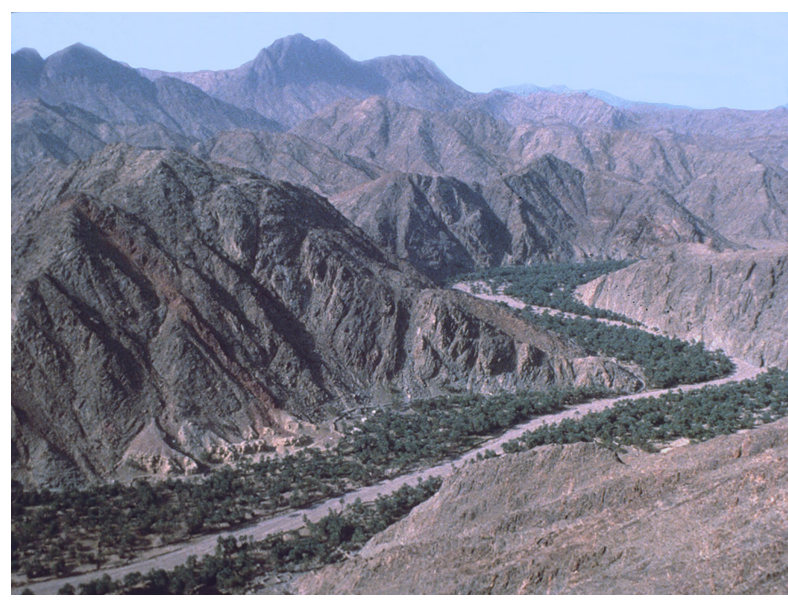

Figure 13 Part of the Feiran Oasis, view from Jebel Moneijah.

named Pharan/Phara/Fara (see below). The 'Arabic name of the wadi obviously follows the biblical name, much like Punon-Faynan (see above), but the similarity of names is not enough to determine its location. In this area, 43 Nabataean inscriptions were included in the CIS II in 1906, bearing the first or surname "Paran" (פארן, figure 14), spelled just as in the Bible. Two similar inscriptions were added by Negev $(1991,54)$, from southern Sinai and from Wadi Hajjaj, a four day walk from the Feiran Oasis on the way to Aila/Eilat. The latter has been inscribed by "Paran son of "Abdalba'li" ( פארן בר עבדאלבעלי; Negev 1977b, 58-59, No. 233), known as a citizen of Wadi Feiran, (CIS II, No. 1512 and see the map figure 11). ${ }^{97}$ Besides the latter, all other inscriptions are restricted to the Wadi Feiran-Wadi Mukatteb area. This is the only region naming פארן (Paran) in the entire Nabataean domain, encompassing most of Jordan, northern Hejaz, the Negev, and Sinai (e.g., Patrich 1990, 23). This means that the biblical geographical name has been preserved in this area for centuries, obviously by generations of local population. Support for this point and its implications are discussed below. In the second century CE, Pharan was mentioned by the Roman geographer Ptolemy (V.16; Stevenson 1991, 128) as a kome (village), but in the fourth century CE as a polis (town) by Eusebius (Onomasticon 142, 22-25; Freeman-Grenville 2003, 92). Also in the fourth century CE, Phara was marked on the Tabula puentingeriana (Nebenzahl 1986, 20-25), but with no symbol of a town. However, at the same time, Phara appears as a strong and well-organized community in the narrative of Ammonius (Mayerson 1980; Caner 2010, 141-71). Unquestionably, the town was located at Tell Mahrad, on the western end of the Feiran palm grove, ${ }^{98}$ where excavations by Grossmann (1996, 2000, 2007) exposed important Byzantine and Nabataean remains.

Another biblical name common in Nabataean inscriptions in this region is Qini/Qinw/'Ibnal-Qini (קיני/קינו/אבנ-אל-קיני) and similar forms (figure 15) (see Starcky 1979, 38-39). It occurs 72 times in southwestern Sinai, mainly in the areas of turquoise and copper mines mentioned above, 40 to $60 \mathrm{~km}$ northwest of Paran (Starcky 1979, 38-39; Negev 1991, 9, 58). This is the same area around Serabit al-Khadem, where the name Qeni already appeared in the early second millennium BCE. Here, we find again the Qenite connection to the copper

97 One more inscription probably bearing this name occurs in northern Hejaz (Negev 1991, 54, Note 1), but his reference seems erroneous and could not be followed.

98 The nineteenth-century explorers described the oasis with a running stream (see, e.g., Bartlett 1849, Figure in P. 52). In 1996, the palm grove was in a good condition, as it was during the 1970s and 80s. Today, however, almost all trees are dead, due to over-pumping of underground water. 


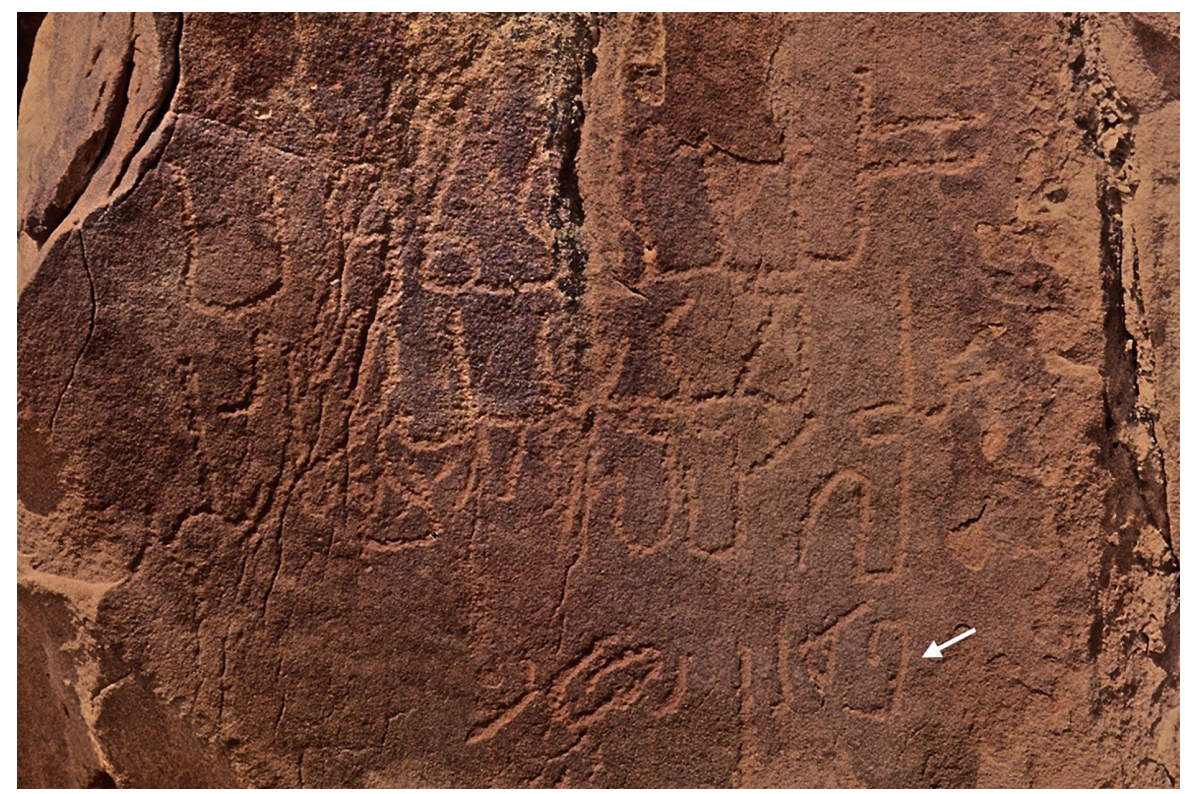

Figure 14 Two Nabataean inscriptions from Wadi Mukateb, southern Sinai, the lower bears the surname "Paran," indicated by the arrow.

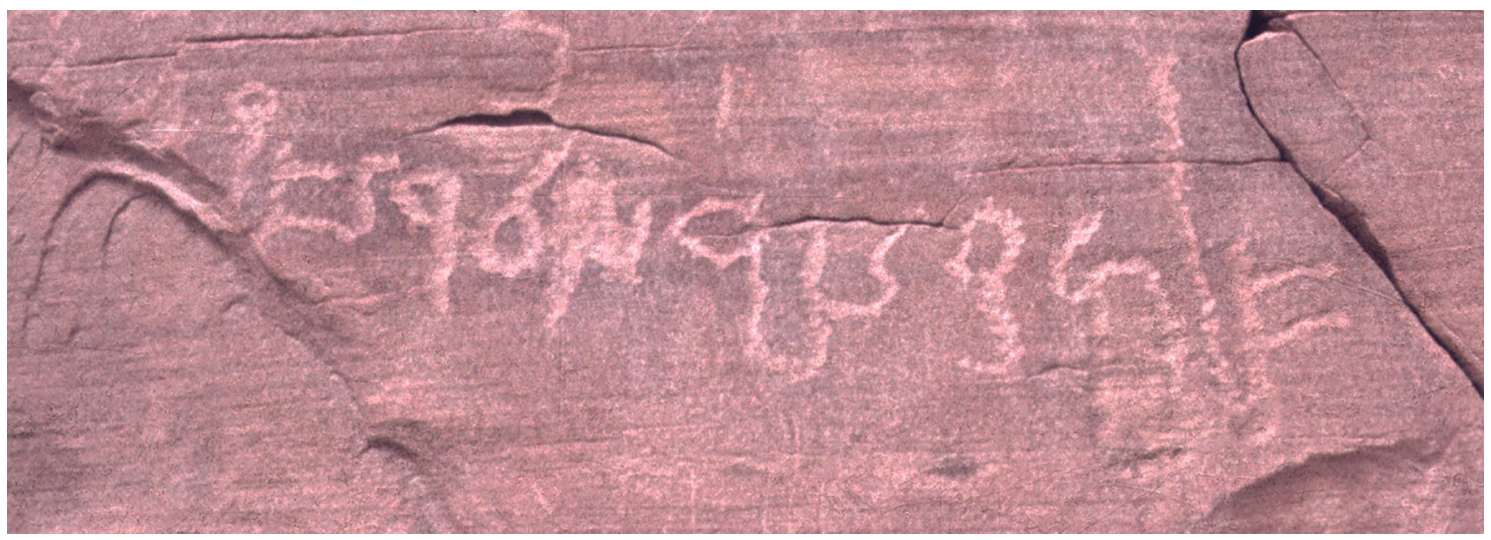

Figure 15 Nabataean inscription from Wadi Hajjaj, southeastern Sinai, of Qinw son of Awishw (see Negev 1977b, No. 18).

sources, in different periods. Unlike "Paran," the Qeni-related names are also found elsewhere in the Nabataean sphere, but in lower numbers (Negev, above). All these inscriptions follow the common Nabataean characters and formulas (see further below).

\section{Two Mountains}

Two of the mountains above the Feiran Oasis bear religious interest. One is Jebel Serbal, a granite mountain, 2070 meters above sea level, steeply rising 1300 meters above the Feiran Oasis (figure 16). During the nineteenth century, several scholars visited the mountain. ${ }^{99}$ They mentioned Nabataean inscriptions and a stone mound next to the summit knob. Lepsius (1853, 532-62) dedicated a long discussion to it, identifying the mountain with the biblical Mount Sinai, as did Currelley, expressing Petrie's opinion (in Petrie 1906, 251-4).

During my first visit to the mountain (in June 1979), I recorded several built elements just 


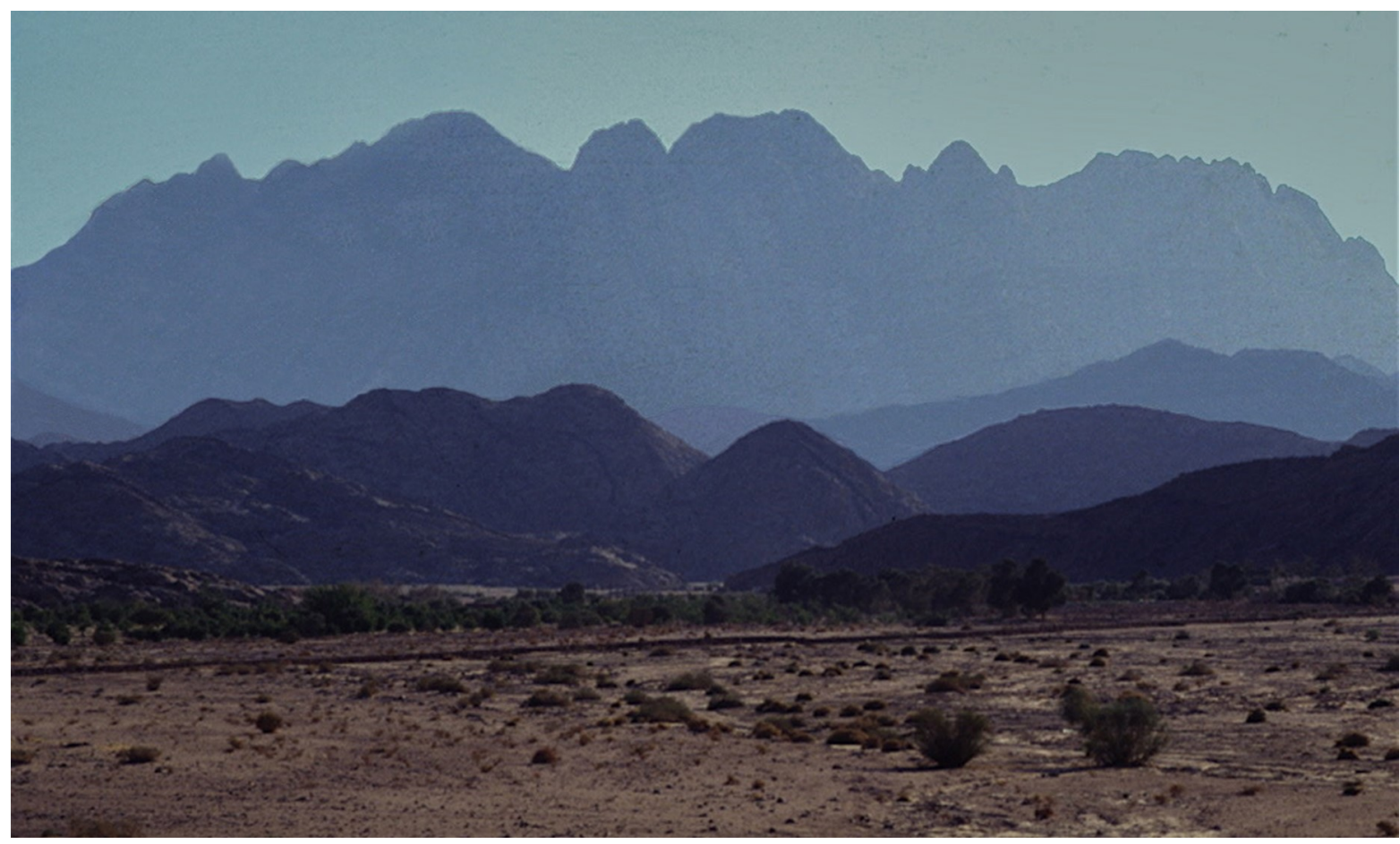

Figure 16 Jebel Serbal, looking from the eastern end of the Feiran Oasis.

below the summit and 70 Nabataean inscriptions. Observing the stone mound (approx. $8 \mathrm{x}$ $8 \mathrm{~m}$, up to $1.1 \mathrm{~m}$ high), I noticed several clues indicating it was actually a ruin of a small Nabataean temple. A following dig proved this correct, and important finds were uncovered (Avner 2015, 398-405). One find should be mentioned here: a silver coin of 'Abdat II, 30-9 BCE. ${ }^{100}$ As to the inscriptions, 20 were already included in the CIS II (Nos. 2104-2123), four were added by Negev (1971, Nos. 30-33), while others were catalogued by Stone based on photographs of myself and of others (see index in Stone 1994, 234). One inscription mentions the title אבפלא i.e., high priest (figure 17). ${ }^{101}$ The temple was in use at least from the first century BCE to the third century CE (Avner, above).

Jebel Moneijah is lower, $1165 \mathrm{~m}$ above sea level, but also steeply rises $515 \mathrm{~m}$ above the Feiran Oasis (figure 18). Its full name is Jebel Moneijat Musa, i.e., "the mountain of Moses' meeting" (with God), based on a Bedouin tradition perceiving Moses as the patron of herds and shepherds. In 1868, the summit was visited by Wilson and Palmer $(1869,213 ; 1871,173-4)$, who described a Bedouin cult enclosure (today $5.5 \mathrm{~m}$ across and $1.5 \mathrm{~m}$ high, figure 19) where the Bedouins sacrificed to Moses and left votive offerings. ${ }^{102}$ Palmer copied 15 Nabataean in-

100 When published, the coin was attributed to 'Abdat III. However, the identification of 'Abdat II has been recently rescinded (Barkai 2016), so 'Abdat III is called now 'Abdat II.

101 The title אכפלא is clear, though not included in the CIS, but unfortunately, the priest's name is illegible (see Negev 1971, 184). For the title's meaning, see Savignac (1933, 412); Negev (1977b, 229); Healey (2001, 163-65, with references).

102 Three other mountains in southern Sinai bear the same Bedouin name, Jebel Moneijat Musa. Two are northwest of the Feiran Oasis and one is just east of Jebel Musa (Mt. Moses). Since the Bedouin tradition seems to continue the Nabataean one (see below), several mountains in southern Sinai were apparently sanctified by the Nabataeans, bearing the tradition of Moses. Jebel Musa itself could be one, since many Nabataean inscriptions are found on and around the mountain. Indeed, Palmer $(1871,6)$ suggested that Jebel Musa was originally named Jebel Moneijah, but since it became sacred to Christians, the name was transferred to the neighboring mountain. 


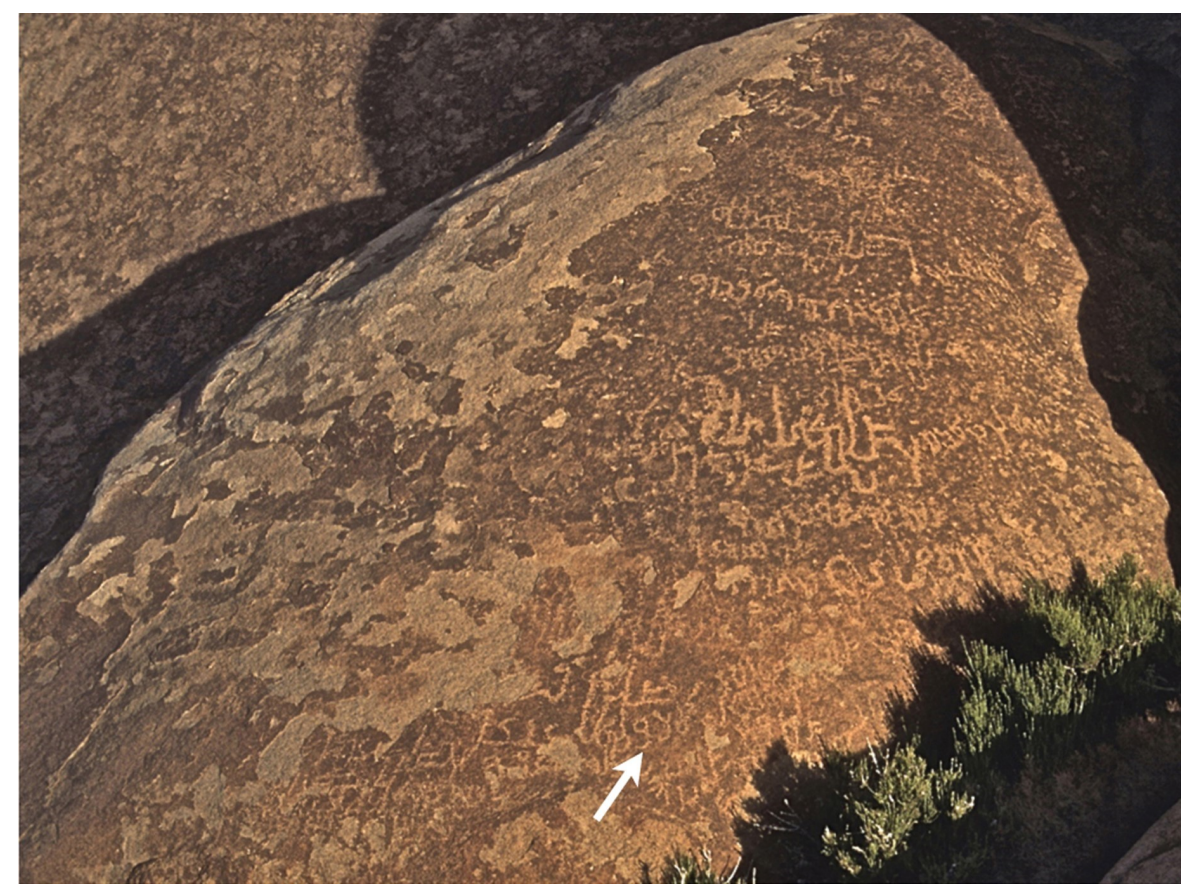

Figure 17 Nabataean inscriptions at the top of Jebel Serbal, the title "אכפלא" (high priest) is indicated by the arrow.

scriptions engraved on the enclosure's stones (figure 20), but thought they were unimportant. Later, 17 inscriptions were included in the CIS II. ${ }^{103}$ These inscriptions contained a surprisingly large cluster of priestly titles: מבקרא (six times (sacrifice inspector) four times; one כתבא (priest); and one כהנא (scribe, figure 19). A few Nabataean pottery sherds collected around the precinct (by me) are dated between the first century BCE and the first century CE. However, one inscription is dated $219 \mathrm{CE},{ }^{104}$ so this Nabataean sacred place was in use for at least 300 years, as was the sanctuary of Jebel Serbal.

In 1976, the site was visited by S. Levi and A. Goren, who added 13 inscriptions from the trail leading up to the summit, which were published by Negev (1977a). One inscription added one occurrence of the title אכפלא. Levi (1977; 1987, 396-7) described the Bedouin custom based on interviews with informants. In brief, once a year young shepherds (boys and girls) walked up to the precinct with their flocks to perform a ritual under the auspices of Musa (Moses) to ensure the herds' fertility. In addition to the annual event, Bedouins from all southern Sinai used to undertake pilgrimage to the mountain during several holidays, as well as on private occasions. One man, Jum'a, of the Feiran Oasis, was in charge of the enclosure and its maintenance.

During my three visits to Jebel Moneijah (twice in 1979, once in 1996), I was told that the ritual was still practiced (I did not manage to attend it, and at present, 2021, I have no information about it). In the precinct, beads, buttons, coins, and other small offering objects were found, mainly in a small niche in the southern wall. On the enclosure walls, the published inscriptions were visible and legible, but I also noticed others inscribed on stones incorporated

103 CIS II, Nos. 2659-2663, 2665-2669, 2671, 2673-2679.

104 Only eight Nabataean inscriptions in southern Sinai bear a date (CIS II 2, Nos. 963, 964, 1325, 1491, 2666; Negev 1967, Nos. 1, 2, 1981 No. 9). They refer to 106 CE, the death of Rabael II and annexation of the Nabataean kingdom to the Roman Empire. The inscription from Jebel Moneijah (No. 2666) mentions "year 113," i.e., 219 CE. 


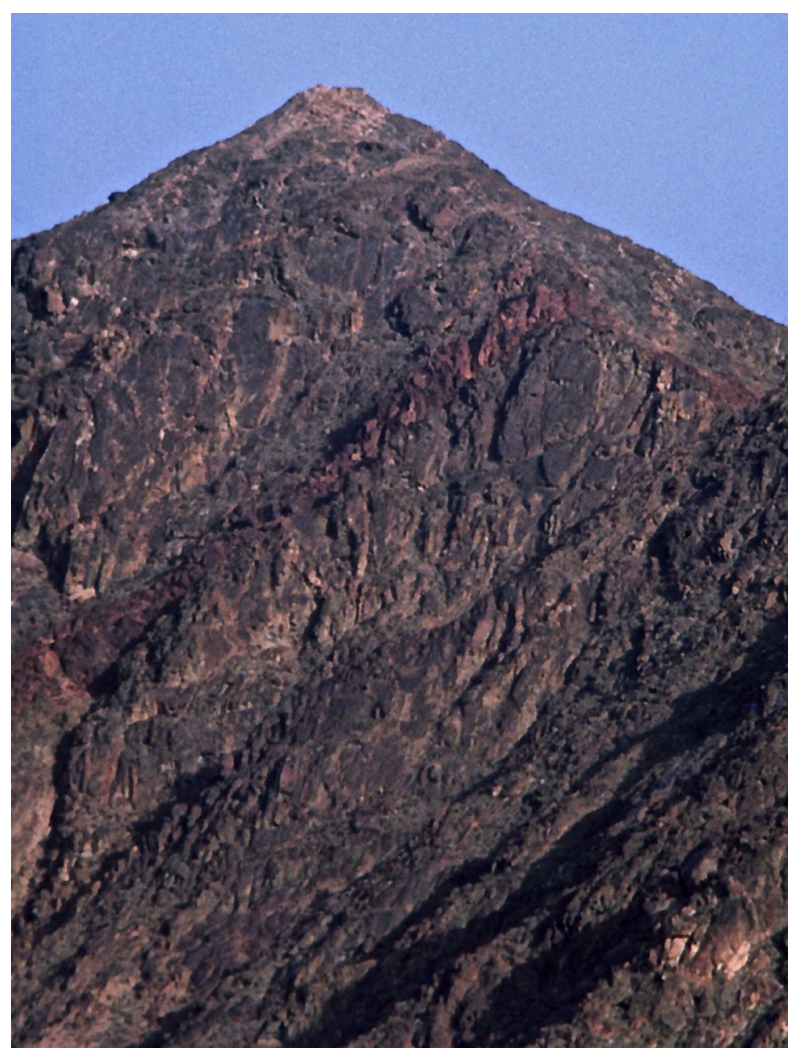

Figure 18 Jebel Moneijah, view from the Feiran Oasis.

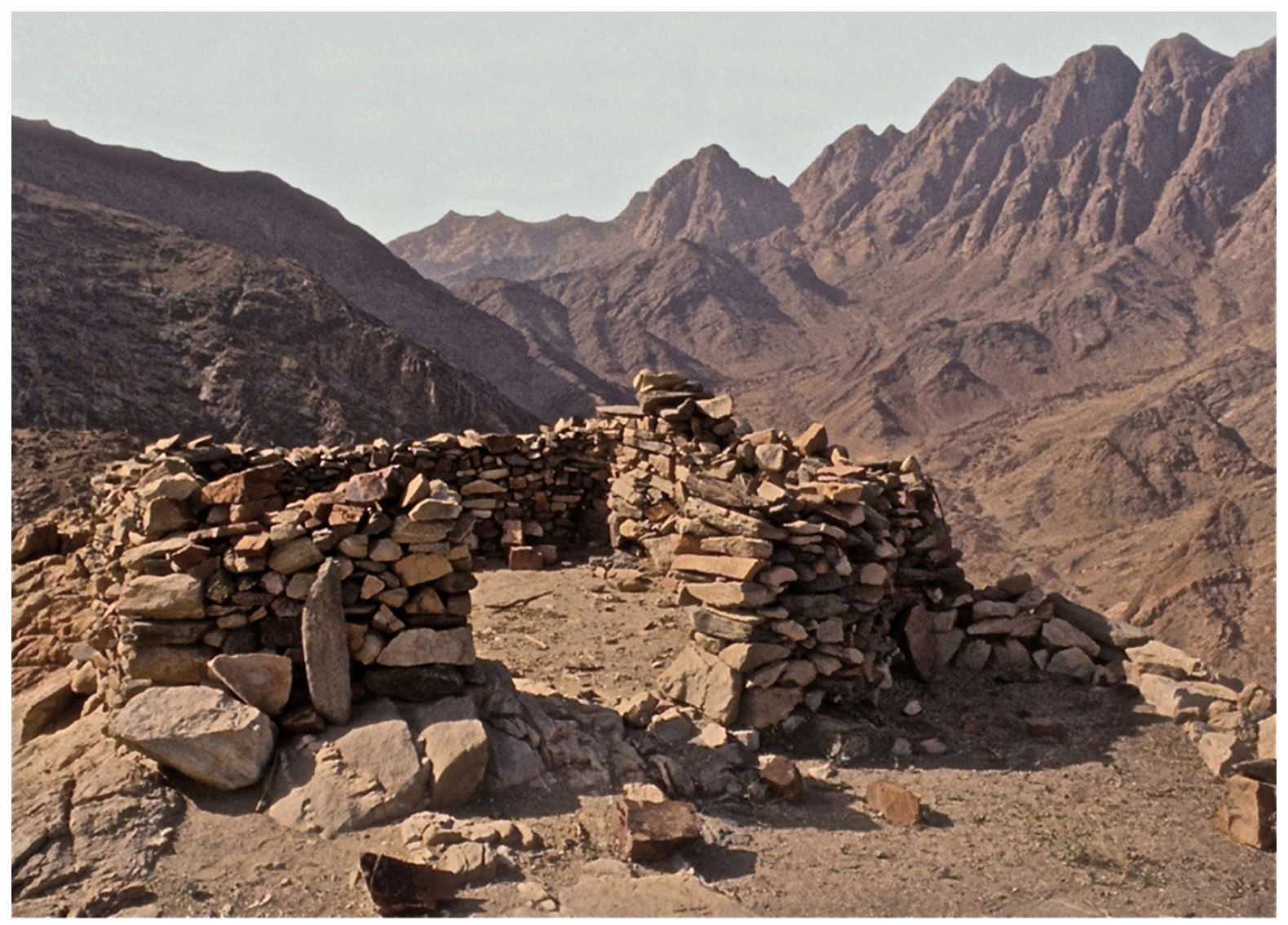

Figure 19 The Bedouin cult enclosure at the Summit of Jebel Moneijah, view from the north. 


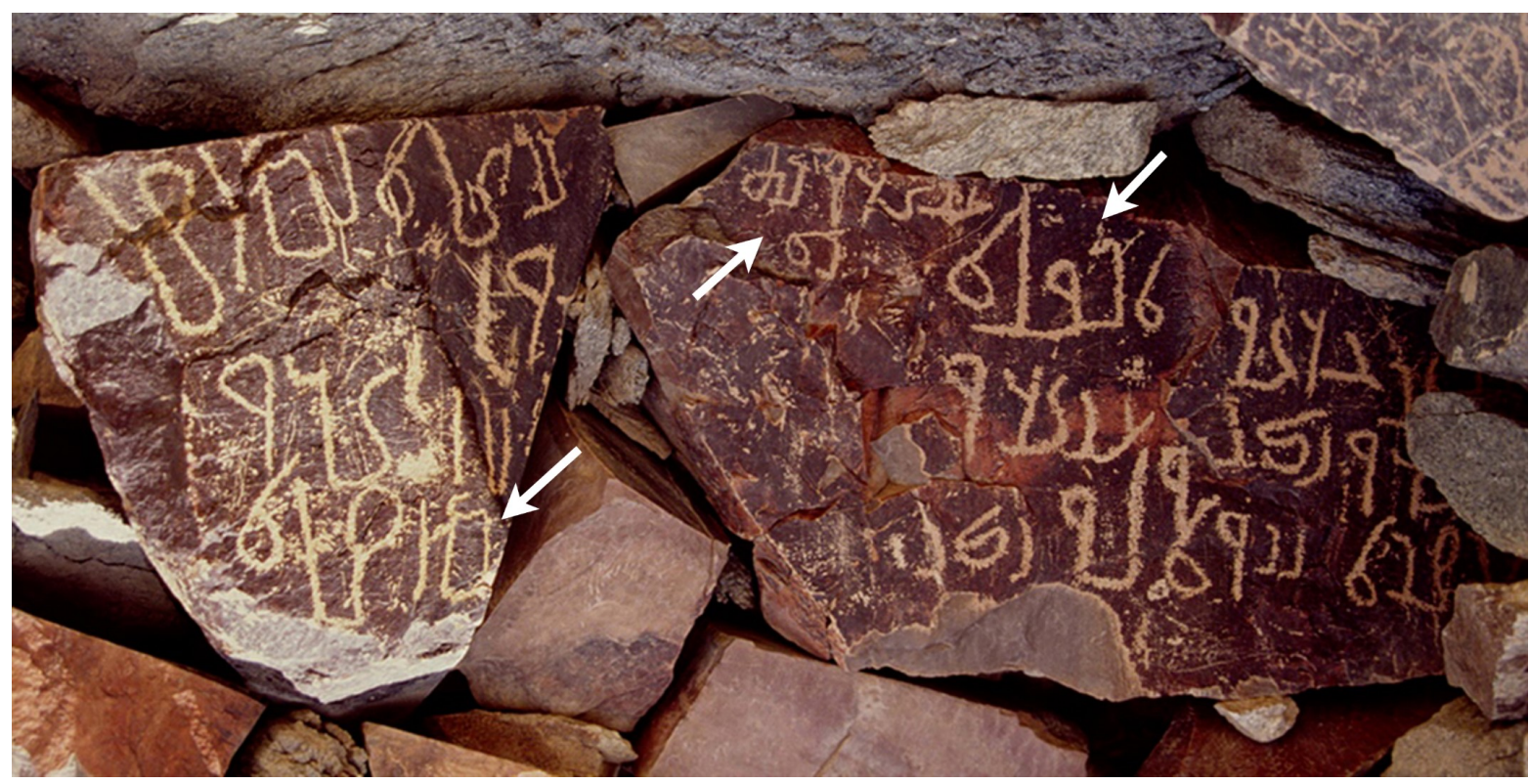

Figure 20 Nabataean inscriptions in the Bedouin cult enclosure of Jebel Moneijah, the titles are

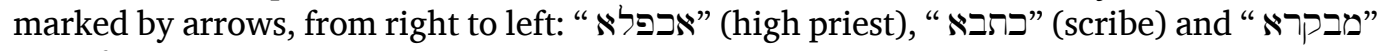
(sacrifice inspector) (CIS II 2, Nos. 2667-8).

within the walls. I was able to pull some out for documentation and place them back into the wall; others I could only partly copy from inside the walls. Hence, the walls may still contain more unseen inscriptions. Altogether, I counted 45 inscriptions in the enclosure alone and three more 7 meters to the southwest. Forty-four inscriptions could be read and they increased the number of מבקרא אפבלא/אכפלא- to eleven and seven. Remarkably, Jebel Moneijah is the only site known to date in the entire Nabataean sphere with such a high number of priestly titles. No doubt the inscriptions, especially these with clergy titles, attest to a past Nabataean temple of greater importance than that of Jebel Serbal (where only one inscription bears a priestly title).

The position of Jum'a, as described by Levi, recalls the title ביתיא ("in charge of the house"), mentioned in eleven Nabataean inscriptions in southern Sinai. ${ }^{105}$ The referred "house" is most probably a temple, similar to the "house" in a Nabataean inscription from Madain Salih, northern Hejaz (Healey 1993, 34, 230). In the Bible, however, the title relates to the king's palace (see below). ${ }^{106}$

\section{Nabataean Religion in Southern Sinai}

The intensive occurrence of priesthood titles in southern Sinai, unparalleled in any other

Nabatean territory, must attest to the religious importance of the region. On Jebel Serbal, Dushara, the chief Nabataean god, was worshiped (Avner 2014, 402). On Jebel Moneijah, the worshiped deity/deities is/are unknown, but the names of two priests mentioned in the inscriptions may yield a clue. One is גרמאלבעלי בר ואלת ("Garm-alBa'ali son of Walat,"

105 Ten inscriptions bear the same name- עבדאלבעלי בר עמיו בר חלצת (CIS II:1612, 1814, 1969, 1985, 2068, 2086, 2501, 2514, 2648, 2845), one (2226) belongs to בר על עליו. (...)

106 The title occurs seven times in the Bible (2Kings 18:18, 19:2, 22:5; Isaiah 22:15 etc.), on the Siloam inscription (Avigad 1953) and on a seal from Tell Duweir/Lachish (Hooke 1935). However, in most of these cases the title is secular. For the Nabataean title, see Negev (Negev 1977a, 229). 


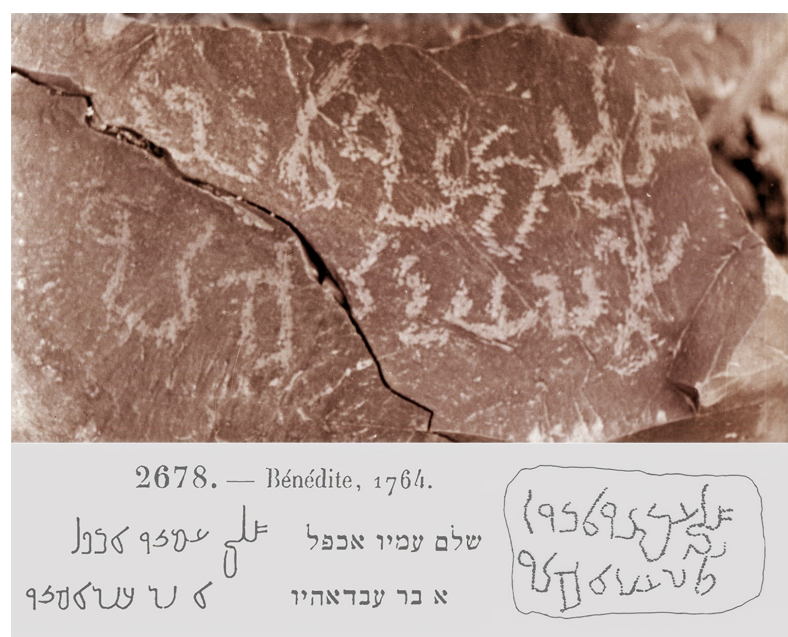

Figure 21 Jebel Moneijah, Nabataean inscription: "Peace (to) 'Amiu, high-priest, son of 'Abdahiu" (CIS II 2, No. 2678, TAB. XXXVIII).

CIS II, 2678), the other- עמיו בר עבדאהיו (“"Amiyw son of "Abd-Ahyw," figure 21, CIS II 2678). Hence, three deity names occur here, alBa'ali (=Ba'al), Walat (=Alat), and Ahyw (=Yahw; Starcky 1979, 39-40; Zayadine 1990, 159-64). The name 'Abd-Ahyw is a direct parallel to the biblical "Obadyahw in charge of the house" of King Ahab (1Kings 18:3), to two occurrences of 'Obadyahw in the "Arad ostraca (Nos. 10, 49, Aharoni 1981, 24, 80, the latter incomplete), to 'Obadyw of the Shomron ostracon No. 50 (Reisner, Fisher, and Lyon 1924, 237, 242), and to 'Obadyw at Kuntilat 'Ajrud (Ahituv, Eshel, and Meshel 2012, 76-77).

Besides Jebel Serbal and Jebel Moneijah, priestly titles and deity names occur in several other inscriptions in the same vicinity (CIS II:825; 969, 2188; Negev 1971, No. 33). The

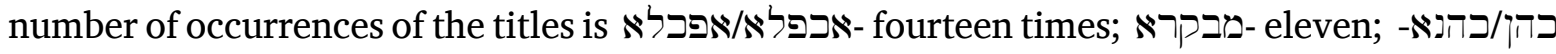

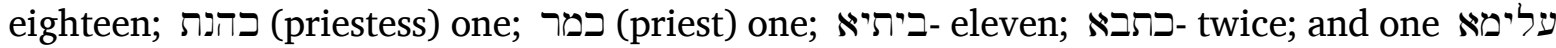
('Alima), most probably in charge of a cemetery (Hebrew- בית עולם, Aramaic- בית עלמין). Fourteen other inscriptions mention-“(...) כהן (...)“(..), priest of (..)"), with the name of the deity they served: al-'Uzia, T'a, Alat, Bubak/kayubak (for details and references, see Avner 2015, 404-6). Altogether, 61 priestly titles occur in the Feiran area, compared to a total of only eight occurrences in the entire vast Nabataean sphere. ${ }^{107}$ In addition, priestly titles also appear in the Feiran area as personal names: seven times אלכהנו (al-Kahanw) and 102 times מבקרו/אלמבקרו (Mabqarw /al-Mabqarw).

Deities are also directly invoked by their names in inscriptions. Dushara is known only once in the Feiran area (CIS II, 2912), but three other inscriptions bearing his name were added by Stone and Avner from Wadi Shellal, $30 \mathrm{~km}$ northwest of the Feiran Oasis, where he is mentioned together with Al-Ba'ali, ${ }^{108}$ who is also mentioned in CIS II 1479. ${ }^{109}$

107 Five times כמר (singular and plural), and one כהכלא, two in Petra, Wadi Ram, and Madain Salih (Healey 1993, 160-2, 2001, 162-5 with references).

108 Avner (2015, Fig. 20). The inscriptions were recorded by M. Stone and myself during a brief survey in Sinai in 1979/80 six 5-day excursions, Stone (2017)]. They were preliminarily read by the late J. Naveh and by H. Misgav but remained unpublished. For further information, see Stone (Stone 1992, esp. Nos. 5618-5858 and Sites 90-97).

109 These figures are based on my own count from the CIS II, and from Negev (Negev 1977b, 1991, 2, 9-69, 80), but do not include the 1047 inscriptions of Stone's survey. These remained undeciphered, a task that I could not undertake. For the identification of Ahyw with Yhwh, and identification of other gods, see Starcky [(1979), 39-40; Zayadine (1990, 159-64). 
Much interest is found in the frequency of Nabataean and non-Nabataean theophoric elements in personal names in the Sinai inscriptions:

\begin{tabular}{ll}
\hline Inscriptions (Nabataean) & \\
\hline Walat (Alat) & 18 \\
Algya'/Alga' ('Abd-alGya) & 10 \\
Dushara (e.g., Tym-Duahara) & 8 \\
'Abdat (e.g., 'Abd-'Abdat) & 6 \\
Hartat (e.g., 'Abd-Hartat) & 2 \\
'Uzai/'Uzia (e.g., 'Abd-'Uzia) & 1 \\
Shai'a' ('Abd-Shai'a' ?) (?) & 1 \\
Total & (?46) 45 \\
\hline \multicolumn{2}{|}{} \\
\hline Inscriptions (Non-Nabataean) \\
\hline alBa'ali (Ba'al) (e.g., 'Abd-alBa'ali) & 456 \\
Alahi (El) (e.g., 'Abd-Ala'hi) & \\
Ahyw (Yahw) ('Abd-Ahyw) & 278 \\
'Anat ('Anat-alhi) & 16 \\
Sarapius (Sarapyu) & 3 \\
Qos (Qos-'adar) & 7 \\
Total & 1 \\
\end{tabular}

Interestingly, the non-Nabataean gods outnumber the Nabataean ones by 16.5 times as theophoric elements in names.

\section{Biblical Implications of the Nabataean Evidence}

The finds from Jebel Serbal and Jebel Moneijah, especially the inscriptions, illuminate several points relating to the biblical narrative, despite the time gap:

1. The remarkable cluster of clergy titles, deity names, and theophoric elements in personal names around the Feiran Oasis indicates that during the Nabataean era and later, the region was exceptionally important religiously. Since the area is far from the Nabataean centers and from the trade routes with Arabia, there must have been another, specific reason for this religious importance. The only apparent source for this unique phenomenon is a deep, older tradition.

2. The predominance of non-Nabataean deity names, invoked or mentioned in the inscriptions (97.7\%), and the predominance of non-Nabataean theophoric elements in names (94.3\%), imply that the majority of the population in the Feiran Oasis, or even in southern Sinai in general, was autochtonic (see Starcky 1979). This population, much like other ethnic groups in the Nabataean sphere, assimilated into the Nabataean culture

110 'Abd-ahyw also occurs in a Nabataean inscription at Bir Umm Enab, the Eastern Desert of Egypt (Littmann and Merdith 1953, 7, Pl. IV). 
(see Graf 2004, 2007, 182), adopted Nabataean gods, but mainly adhered to its old gods. This was the very population that preserved the biblical geographical name of the region: Paran.

3. During the Byzantine Period (early fourth to early seventh centuries), the Christian monastery of St. Katerina was first built, and many smaller monasteries and laurae were established. The monks formed a sacred tradition around Jebel Musa, Jebel Katerina, the Feiran Oasis, and a number of other sites (Dahari 2000; Caner 2010; Ward 2015, esp. 52-4, 76-80). These monks could seemingly be the source for the present-day Bedouin tradition surrounding Moses. However, the strong religious character of the Feiran region is obviously pre-Christian. Therefore, the autochtonic population of the Nabataean time was the natural source for the early Christianity in Sinai regarding the tradition of Moses and the sacredness of the mountains (see Ward 2015, 70-91), as well as for the Bedouin tradition. ${ }^{111}$

4. Ahyw-Yahw was one of the old gods of this autochtonic population, who was still known and worshiped by some in the third century CE. His Nabataean spelling, and probably also pronunciation, was close to that of the aforementioned Ahiu/Ihiu in the Theban stela of Akhtoy, of the late third millennium BCE.

5. The religious importance of the Feiran area and its antiquity is further illuminated by the words of Diodorus, first century BCE: “(...) This region is called the 'Palm Grove' (Phoinikon) and contains multitude of trees of this kind, which are exceedingly fruitful and contribute an unusual degree of enjoyment and luxury (...). Moreover, an altar is built there of hard stone and very old in years, bearing an inscription in ancient letters of an unknown tongue. The oversight of the sacred precinct is in the care of a man and a woman who hold the sacred office for life." 112 The "ancient letters" mentioned by Diodorus could not be Greek, Egyptian, Nabataean, Thamudic, or Aramaic, which were all known in his time, so the remaining option for "very old" script is the Proto-Sinaitic, addressed above. Diodorus' description strongly support the pre-Christian sacred tradition of the region.

6. The Feiran Oasis and the two sacred mountains may have been the destination of the religious groups from Israel and Judah who travelled through Qadesh Barne'a, Kuntilat 'Ajrud, and Darb Sha'ira. It could also be the route related to Elijah on his way to Mount Horeb (1King 19). Truly, very few Iron Age remains are known to date in southern Sinai, but some can be mentioned. An unpublished survey of B. Mazar in 1957 on Tell Mahrad (referred to by Rothenberg 1961, 166) mentioned the collection of pottery of the Iron Age II, the Persian and Hellenistic periods, numerous Nabataean sherds and pottery of later periods. In 1970 I found one rim fragment of an Iron Age II jar in Wadi Nefus, a

111 For the perpetuation of old traditions among the present day Bedouins of Sinai, see, e.g., Levi (1977, 1980); Negev (1977a); Hoffmeier (2005, 140-8).

112 Diodorus III:42.2-4, translated by C. Oldfather, LCL 1935, see Strabo XVI. 4.18, first century CE. The "Palm-Grove" of the classic sources is identified either at Wadi Feiran (e.g., Negev 1977c, 553) or at alTur-Rhaithou (Wenning 1987, 162; Teixidor 1998, 86). However, nine volumes of Kawatoko et al. known to me (1995), published on a survey and extensive excavations at al-Tur, uncovered a Byzantine monastery (see Dahari 2000, 138-40; Caner 2010, 154-9, etc.) and a large Islamic complex, but no Nabataean remains or inscriptions. Hence, the Feiran Oasis, with its thousands of palm trees, the remains of a Nabataean town, and hundreds of Nabataean inscriptions, is the sole candidate for the ancient "Palm Grove." 
northern tribute of the Feiran Oasis. In any case, an absence of evidence is not evidence of absence, and the words of Diodorus are certainly interesting in this context.

\section{Summary}

In the attempt to contribute some data to the ongoing debates, this article addresses two related issues, as indicated in the title. In my view, the desert roots in ancient Israel support the southern origin of Yhwh, while Yhwh's southern origin illuminates the role of desert tribes in the formation of early Israel. Although the data presented here are not new, some were overlooked or underutilized in published analyses. Assembling the data from a variety of sources provides a broader picture of the desert's history, of some aspects of the ethnogenesis of Israel, and of the origin of its God. In brief, the desert tribes brought their desert God to the "mixed multitude" of groups that gathered in Cana'an, and under a covenant with this God created a confederation that later evolved to a nation (עם) named Israel (see Gottwald [1979] 1999, 693-9, 705-10; Stager 1989, 142-51; Mendenhall 2001, 77-81). ${ }^{113}$

The aforementioned three groups of sources, biblical passages, Egyptian texts, and the Kuntilat 'Ajrud inscriptions, associate Yhwh to the desert (Se'ir, Sinai, Edom, Paran, Horeb, Teman, and Qadesh) and form a consistent attestation to his southern origin. The late third millennium BCE Egyptian text relating Ahiu to copper mining in southwestern Sinai, and its identification with Yhwh, are only probable, but they gain some support from additional sources. Identification of the Paran Desert in southern Sinai seems conclusive, based on the perpetuation of the name in many Nabataean inscriptions in the Feiran region. This concurs well with the additional data: the geographical connection of southern Sinai with Kuntilat 'Ajrud, the unique religious lore of the area, and the persistence of the Moses tradition among the present-day Bedouins. This does not mean that Jebel Moneijah or Jebel Serbal should be identified as Mount Sinai, which many explorers and scholars attempted to locate, not only in Sinai. It would be enough to say that southern Sinai could be the source of important elements in the Exodus narrative and in the formation of the Israelite collective tradition.

The deep desert roots in the culture of Israel cannot be fictive; they must reflect the people's notions and a reality. Seeing Israel as a "mixed multitude" of ethnic groups gathering from various origins (Egypt, Mesopotamia, Anatolia Cana'an, Transjordan, Se'ir, Mediterranean islands) means that a long formation process was needed to solidify the nation. Naturally, during this process, each group strived to influence the others from its own culture (as occurs in modern-day Israel), including through conflicts. This is the reason why the Bible, even after Deuteronomistic and Priestly editions, still contains several different theologies (see, e.g., Zevit 2001; LaRocca-Pitts 2001; Avner 2006), again, much like today. In this cultural competition, the desert groups, the Shasu, managed to gain the strongest influence on Israel's social framework, on its law, and most of all on its spiritual culture. Hence, the desert tribes were probably a 'core group' in the forming nation. ${ }^{114}$

Introduction of Yhwh into the Land of Cana'an/Israel by the desert tribes should not be underestimated, since the worship of other gods was well established long before his arrival. ${ }^{115}$

113 For a confederation headed by a deity, see, e.g., the words of Aserhadon: "I inflicted a defeat upon the Isamme', a confederation of the god Atarsamain (...)" (ANET 299, with references in Note 12).

114 See Rendsburg (1997, esp. 450); Ahituv (1998); Rainey (2008a, 44-45); Faust (2018, 2-3).

115 There are several different theories as to the coming of Yhwh into the settled Israel. See, e.g., de Vaux ([1958] 1961, 294-311); Smith (1990); Lemaire (2007); Römer (2015); Tebes (2017). According to Mettinger (1990, 408), Yhwh of Judah and of Israel was the same God, originated in the region around the 
The success of the Shasu in introducing their God is demonstrated by the dominance of the theophoric elements Yahu, Yah, and Yw in personal names in Judah and Israel. A study of Mitka Golub (2017) collected Hebrew names from the books of Kings and Chronicles, and from epigraphic finds, i.e., ostraca, inscriptions, seals, and seal impressions. Out of 511 names, 430 contained the Yahwistic theophoric elements, while only 81 names contained El. Yahwistic names took $84 \%$, against only $16 \%$ of names containing El, despite the fact that El was worshiped in Cana'an long before Yhwh and was also the God of the Patriarchs. ${ }^{116}$ Another study, by Golub (2019), demonstrates a sharp increase of Yahwistic names from the United to the Divided Monarchy. These data represent the growing dominance of Yhwh throughout the first temple time, as also deduced by several scholars (e.g., Lemaire 2007; Römer 2015) before having the updated data of Golub. ${ }^{117}$

One possible problem remains. Yahwistic names became common in the Bible only in the tenth century BCE (e.g., de Moor 1990, 13-20, 32-33), approx. 350 to 200 years after the mention of "the Shasu land Yahu" in Egyptian topographic lists and of Yah in the Book of the Dead. These names occur in lists of high officials of King David (2 Samuel 8:16-18, 20:23-26) and of Solomon (1Kings 4:2-7), lists that seem to be quoted from authentic official documents such as "the book of the acts of Solomon" (1Kings 14:41). ${ }^{118}$ In presently known epigraphic finds, Yahwistic names first occur even later, around 800 BCE (Golub and R. 2017, 36, 2019, 58 , Note 7, and personal communication). However, since only 12 Hebrew names are known to date from epigraphic finds before that, this difficulty may not be significant.

The desert people were certainly inferior to those of the sown lands in material culture and economic resources. Therefore, their ability to influence the others in the spiritual sphere is remarkable. Studying prehistoric cultic remains in the desert (mașeboth, open-air sanctuaries, burials, and mountain cult sites) exhibits the same result in each: the desert inhabitants appear as creative vanguards in theological-philosophical ideas (Avner 2018). What was their source of power? A possible brief answer is that the desert environment combined two different impacts on humans. One is the primordial beauty and vastness of the desert landscape, which served as a source of inspiration; the other is the hardship. Desert people lived with a high degree of uncertainty, particularly with regard to rainfall. ${ }^{119}$ Therefore, they were more dependent on the forces of nature, i.e., on gods. This motivated them to intensive religious activity, which led to religious creativity and thereby to an established religion that empowered them to influence others in this domain. ${ }^{120}$

As mentioned above, the desert lore in ancient Israel could not be merely the outcome of a

head of the Gulf of Eilat. He arrived in Judah from the south, and into Israel from the east, both with the Shasu migrants.

116 de Vaux ([1958] 1961, 289-194); Alt (1966); Cross (1962); Mettinger (1988, 50-74).

117 For previous onomastic studies with similar results, see Tigay (1987); Pike (1990); Zevit (2001, 586-609), and for a deep desert memory in Israel and the position of Yhwh, see Miroschedji (1933). According to others, the cult of Yhwh developed in the northern kingdom of Israel, with only a remote memory of his desert origin (Astour 1979; Finkelstein 2015; Smith 2017; Pfeiffer 2017; Müller 2015; Pakkala 2017). This conclusion does not corroborate the data of Golub (see esp. 2017, Table 1).

118 For the authenticity of these lists, see, e.g., Mettinger (1971, 7-14, 36-44; Gogan 2001, 199-220). For the opposite position, see Ash (1995). For additional Yahwistic names in King David's time, see 1Chronicles 15:17-24.

119 Similarly, in the Ugaritic myth of the Goodly Gods (KTU 1.23, Line 65), the desert is mentioned as a difficult place, but also as "mdbr qdک̌" = "holy desert" (Smith 2006, 25, 99, 116-17). The word $m d b r$ (desert) is translated "outback" by Smith (XIV, Note 1), but based on the biblical Hebrew, the Sages literature and modern Hebrew, mdbr (midbar) is certainly a desert.

120 See the role of the Rechabites, the desert clan, in the religious reform of King Jehu (2Kings 10). 
40-year desert sojourn, nor the result of the Israelites' exposure to the desert during the eighth century BCE or the invention of a late redactor. To some extent, the prehistory of the desert was also the prehistory of Israel - an observation that should encourage further studies.

\section{Acknowledgment}

I am grateful to friends and colleagues who sent to me their publications, referred to in this paper (when libraries were closed due to the coronavirus) in alphabetic order: Niv Alon, Nissim Amzallag, Clinton Bailey, Erez Ben-Yosef, Elizabeth DeGear, Avraham Faust, Israel Finkelstein, Orli Goldwasser, Mitka Golub, David Graf, Liora Horowitz, Ann Killebrew, Tom Levy, 'Amiḥai Mazar, Tryggve Mettinger, Racheli Shlomi-Ḥen, Michael Stone, Pierre Tallet, Orit Shamir, Kenton Spark, Na'ama Sukenik, Juan Tebes, Peter van der Veen and Na'ama Yahalom-Mack. Some of them read the draft and made important comments. I am also grateful to two anonymous readers for their comments. Thanks to Alfonso Nusbaumer, Winnie van der Oord, and Yonel Sharvit, who helped me in reading French and German publications, and to Rina Avner and Michelle Finzi for checking the English of the Manuscript. I also thank the staff of the IAA library in the Rockefeller Museum, Jerusalem, the main library that I was using. Photographs are of mine, unless otherwise is stated, maps and drawings were also made by me, with the assistance of Rahamim Shem-tov.

\section{References}

Abdel-Motalib, A., M. Bode, R. Hauptmann, U. Hartung, A. Hauptmann, and K. Pfeiffer. 2012. "Archaeometallurgical Expeditions to the Sinai Peninsula and the Eastern Desert of Egypt (2006, 2008)." Metalla 19: 3-59.

Adrom, F., and M. Müller. 2017. "The Tetragramaton in Egyptian Sources- Facts and Fiction." In The Origin of Yahwism, edited by J. van Oorschot, 93-113. Berlin: De Gruyer.

Aharoni, Y. 1962. "Issachar and Menasheh in the Beth Shean Valley." In The Beth Shean Valley, edited by The Beth Shean Valley, 31-38. Jerusalem: Israel Exploration Society (Hebrew). . 1968. "Arad: Its Inscriptions and Temple." Biblical Archaeologist 31: 2-32.

. 1976. "The Settlement of the Tribes in the Negev: A New Picture." Ariel 41: 3-24. 1979. The Land of the Bible: A Historical Geography. Edited and translated by A. Rainey. London: Burns, Oates.

- 1981. 'Arad Inscriptions. Jerusalem: Israel Exploration Society.

. 1982a. The Archaeology of the Land of Israel: From Prehistoric Beginnings to the End of the First Temple Period. Philadelphia: Westminster.

- 1982b. "The Israelite Occupation of Canaan: An Account of Archaeological Evidence." Biblical Archaeology Review 8: 14-23.

Ahlström, G. W. 1985. "Merenptah’s Israel.” Journal of Near Eastern Studies 44: 59-61.

Ahituv, S. 1970. "Pashhur." Israel Exploration Journal 20: 75-76.

- 1984. Canaanite Toponyms in Ancient Egyptian Documents. Jerusalem: Magness Press. . 1998. "The Origin of Ancient Israel- the Documentary Evidence." In The Origin of Early Israel- Current Debate. Be'er Sheva', edited by S. Ahituv and E. Oren. Beersheva: Ben Gurion University Press. 
1999. "The Negev Nomads in the Egyptian Sources." In Ki Baruch Hu: Ancient Near Eastern, Biblical and Judaic Studies in Honor of Baruch Levine, edited by R. Chazan, W. W. Hallo, and L. H. Schiffman, $21^{*}-27^{*}$. Winona Lake: Eisenbrauns.

Ahituv, S., E. Eshel, and Z. Meshel. 2012. "The Inscriptions." In Kuntilat 'Ajrud (Horvat Teman): An Iron Age II Religious Site on the Judah-Sinai Border, edited by Z. Meshel and Z. Meshel, 73-142. Jerusalem: Israel Exploration Society.

Albright, W. F. 1935. "Archaeology and the Hebrew Conquest of Palestine." Bulletin of the American School of Oriental Research 58: 10-18.

- 1939. "The Israelite Conquest of Canaan in the Light of Archaeology." Bulletin of the American Schools of Oriental Research 74: 11-23.

. 1963. "Jethro, Hobab and Reuel in Early Hebrew Tradition." Catholic Biblical Quarterly 25: 1-11.

— 1966. "The Proto-Sinaitic Inscriptions and Their Decipherment." Harvard Theological Studies 22: 1-45.

- 1968. Yahweh and the Gods of Canaan. A Historical Analysis of Two Contrasting Faiths. London: University of London.

— 1969. The Proto-Sinaitic Inscriptions and Their Decipherment. Cambridge: Harvard University Press.

Alon, N., and H. Navratilova. 2017. Ancient Egyptian Scribes : A Cultural Exploration. New York: Bloomsbury.

Alt, A. 1924. "Neues über Palästina aus dem Archiv Amenophis IV." Palästinajahrbuch des Deutschen Evangelischen Instituts Für Altertumswissenschaft des Heiligen Landes zu Jerusalem 20: 22-41.

- 1966. Essays on Old Testament History and Religion. Edited and translated by R. A. Wilson. Garden City, NY: Doubleday.

Amzallag, N. 2019. "The Religious Dimension of Copper Metallurgy in the Southern Levant." In Isaac Went Out. . . To the Field" (Genesis 24:63): Studies in Archaeology and Ancient Cultures in Honor of Isaac Gilead, edited by H. Goldfus, M. Gruber, S. Yona, and P. Fabian, 1-13. Oxford: Archaeopress.

Anati, E. 2001. The Riddle of Mount Sinai: Archaeological Discoveries at Har Karkom. Valcamonica: Edizioni del Centro.

Arav, R., S. Filin, U. Avner, and D. Nadel. 2016. "Three-Dimensional Documentation of Masseboth Sites in the 'Uvda Valley Area, Southern Negev, Israel." Digital Applications in Archaeology and Cultural Heritage 2016: 1-13.

Ash, P. S. 1995. "Solomon's? District? List." Journal of the Study of the Old Testament 67: 67-86.

Astour, M. C. 1979. "Yahweh in Egyptian Topographic Lists." Ägypten Und Altes Testament 1: 17-34.

. 1999. "The Hapiru in the "Amarna Texts." Ugarit Forschungen 31: 32-50.

Averbeck, R. E. 2016. "The Egyptian Sojourn and Deliverance from Slavery in the Framing and Shaping of Mosaic Law." In Did I Not Bring You Out of Egypt?: Biblical, Archaeological and Egyptological Perspectives on the Exodus Narratives, edited by J. K. Hoffmeier, A. R. Millard, and G. A. Rendsburg, 143-76. Winona Lake: Eisenbrauns.

Avigad, N. 1953. "The Epitaph of a Royal Steward from Siloam Village." Israel Exploration Journal 3: 137-52.

. 1972. "Excavations in the Jewish Quarter of the Old City of Jerusalem, 1971: Third Preliminary Report.” Israel Exploration Journal 22: 193-200. 
Avner, U. 1979. "Emergency Survey in 'Uvda Valley." Hadashot Arkheologiyot 69-71: 17-18.

— 1984. "Ancient Cult Sites in the Negev and Sinai Deserts." Tel Aviv 11: 115-31.

. 1993. "Mașseboth Sites in the Negev and Sinai and Their Significance." In Second International Congress on Biblical Archaeology in Jerusalem 1990, edited by J. Aviram, 166-81. Jerusalem: Israel Exploration Society.

. 2000. "Nabatean Standing Stones and Their Interpretation." Aram 11: 95-120.

. 2001. "Sacred Stones in the Desert." Biblical Archaeology Review 27: 30-41.

. 2002. "Studies in the Material and Spiritual Culture of the Negev and Sinai Population

During the 6th-3rd Millennia BC." Ph.D. dissertation, Jerusalem Hebrew University. ht tps://www.adssc.org/wp-content/uploads/2019/04/PhD-Uzi-RS.pdf.

- 2006. Review of Review of: Of Wood and Stone, the Significance of Israelite Cultic Items in the Bible and Its Early Interpreters., by E. C. LaRocca-Pitts. Journal of Near Eastern Studies 65: 51-55.

— 2014. "Egyptian Timna- Reconsidered." In Unearthing the Wilderness: Studies on the History and Archaeology of the Negev and Edom in the Iron Age, edited by J. Tebes, 10363. Leuven: Peeters.

—. 2015. "The Nabateans in Southern Sinai." Aram 27: 399-432.

—. 2016. "Ancient Roads in the "Araba." The Dead Sea and 'Arava Studies 8: 25-44.

. 2018. "Protohistoric Developments of Religion and Cult in the Negev Desert." Tel Aviv 45: 23-62.

- 2019. "Nabataeans in the Eilat Region, the Hinterland of Aila." Aram 30: 597-644.

—. Forthcoming. "Mașseboth [Standing Stones] in Gates." In Yotvata Hill: An Early Iron Age I Fortress in the Southern Arabah, edited by L. Avitz-Zinger. Tel Aviv: Institute of Archaeology of Tel Aviv University.

Avner, U., H. Ginat, S. Shalev, Shilstine S, B. Langford, A. Frumkin, R. Shem-Tov, et al. 2018. "Ancient Copper Mines at Nahal 'Amram, Southern 'Araba: A New Research.” In Mining for Ancient Copper: Essays in Memory of Beno Rothenberg, edited by E. Ben-Yosef, 147-77. Tel Aviv: Institute of Archaeology of Tel Aviv University.

Axelsson, L. E. 1987. The Lord Came Out from Seir. Lund: Almquist and Wiksell.

Bailey, C. 2018. Beduin Culture in the Bible. New Haven: Yale University Press.

Bar, S. 2008. "Who Were the Mixed Multitude?" Hebrew Studies 49: 27-39.

Barkai, R. 2016. "The Coins of the Nabataean King Obodas II (C. 30-9 BC)." In The Numismatic Chronicle, 176:83-109.

Bartlett, J. R. 1969. "The Land of Seir and the Brotherhood of Edom." Journal of Theological Studies 20: 1-20.

1989. Edom and the Edomites. Sheffield: JSOT Press.

Bartlett, W. H. 1849. Forty Days in the Desert on the Track of the Israelites. London: Bell \& Daldy.

Becher, S. 2018. "Take a Stone and Set It up as a Mașșeba. The Tradition of Standing Stones at Hazor." Zeitschrift Des Deutschen Palästina-Vereins 134: 28-45.

Beck, P. 2012. "The Drawings and Decorative Designs." In Kuntilat 'Ajrud (Horvat Teman): An Iron Age II Religious Site on the Judah-Sinai Border, edited by Z. Meshel and Z. Meshel, 143-204. Jerusalem: Israel Exploration Society.

Beherec, M. A., T. E. Levy, O. Tirosh, M. Najjar, K. A. Knabb, and Y. Erel. 2016. "Iron Age Nomads and Their Relation to Copper Smelting in Faynan (Jordan): Trace Metal and $\mathrm{Pb}$ and Sr Isotopic Measurements from the Wadi Fidan 40 Cemetery." Journal of Archaeological Science 65: 70-83. 
Beherec, M. A., M. Najjar, and T. E. Levy. 2014. "Wadi Fidan 40 and Mortuary Archaeology in the Edom Lowland." In New Insight into the Iron Age Archaeology of Edom, Southern Jordan, edited by T. E. Levy, M. Najjar, and E. Ben-Yosef, 664-721. Los Angeles: University of California.

Beit-Arieh, I. 1985. "Serabit El-Khadim: New Metallurgical and Chronological Aspects." Levant. Journal of the British School of Archaeology in Jerusalem and the British Institute at Amman for Archaeology and History 17: 89-116.

. 1987. "Canaanites and Egyptians at Serabit El-Khadim." In Egypt, Israel, Sinai: Archaeological and Historical Relationships in the Biblical Period, edited by A. F. Rainey, 57-67. Tel Aviv: Tel Aviv University.

- 1995. Horvat Qitmit: An Edomite Shrine in the Biblical Negev. Tel Aviv: Tel Aviv University.

—. 1996. "Edomites Advance into the Negev." Biblical Archaeology Review 22: 29-36.

Ben-Tor, A. 2016. Hazor: Canaanite Metropolis, Israelite City: The Head of All Those Kingdoms (Joshua 11:10). Joshua: Israel Exploration Society.

Ben-Yosef, E. 2016. "Back to Solomon's Era: Results of the First Excavations at Slaves' Hill (Site 34, Timna, Israel)." Bulletin of the American Schools of Oriental Research 376: 16998.

. 2018. "The Central Timna Valley Project: Research, Design and Preliminary Results." In Mining for Ancient Copper: Essays in Memory of Beno Rothenberg, edited by E. Ben-Yosef, 29-63. Tel Aviv: Institute of Archaeology of Tel Aviv University.

—. 2019. "Architectural Bias in Current Biblical Archaeology." Vetus Testamentum 69: 361-87.

Ben-Yosef, E., R. Sha'ar, L. Tauxe, and H. Ron. 2012. "A New Chronological Framework for Iron Age Copper Production in Timna (Israel)." Bulletin of the American Schools of Oriental Research 367: 31-71.

Bertman, S. 1961. "Tasseled Garments in the Ancient East Mediterranean." Biblical Archaeologist 24: 119-28.

Bietak, M. 1987. "Comments on Exodus." In Egypt, Israel, Sinai: Archaeological and Historical Relationship in the Biblical Period, edited by A. Rainey, 163-71. Tel Aviv: Tel Aviv University.

. 2015. "On the Historicity of the Exodus: What Egyptology Today Can Contribute to Assessing the Biblical Account of the Sojourn in Egypt." In Israel's Exodus in Transdisciplinary Perspective: Text, Archaeology, Culture, and Geoscience, Quantitative Methods in the Humanities and Social Sciences, edited by T. E. Levy, T. Schneider, and W. H. C. Propp, 17-37. Heidelberg: Springer.

Biran, A. 1998. "Sacred Spaces: Of Standing Stones, High Places and Cult Objects at Tell Dan." Biblical Archaeology Review 24: 38-45, 70.

Blenkinsopp, J. 2008. "The Midianite-Kenite Hypothesis Revisited and the Origins of Judah." Journal for the Study of the Old Testament 33: 131-53.

Bloch-Smith, E. 2015. "Mașseboth Standing for Yhwh, the Fall of a Yhwistic Cult Symbol." In Worship, Women and War, Essays in Honor of Susan Niditch, edited by J. J. Collins, T. M. Lemos, and S. M. Olyan, 99-116. Providence: Brown University.

Brandle, B. 1984. "A Midianite Bowl from Gezer." Levant. Journal of the British School of Archaeology in Jerusalem and the British Institute at Amman for Archaeology and History 16: 171-72. 
Bright, J. (1959) 1981. A History of Israel. 3rd ed. Philadelphia: Westminster.

Bruins, H., and J. Van der Plicht. 2007. "Radiocarbon Dating of Wilderness of Zin." Radiocarbon 49 (2): 481-97.

Burckhardt, J. L. 1822. Travels in Syria and the Holy Land. London: John Murray.

Caminos, R. A. 1954. Late Egyptian Miscellanies. London: Cumberlege.

Caner, D. F. 2010. History and Hagiography from the Late Antique Sinai. Liverpool. Liverpool: Liverpool University Press.

Cazalles, H. 1973. "The Hebrews." In Peoples of the Old Testament Times, edited by D. J. Wiseman, 1-28. Oxford: Oxford University Press.

Clines, D. J. A. 1983. Midian, Moab and Edom: The History and Archaeology of Late Bronze Age and Iron Age Jordan and North-West 'Arabia. Sheffield: JSOT Press.

Cohen, R., and H. Bernick-Greenberg. 2007. Excavations at Kadesh Barnea (Tell El-Qudeirat) 1976-1982. Jerusalem: Israel Antiquities Authority.

Cohen, R., and R. Cohen-Amin. 2004. "Ancient Settlement of the Negev Highlands Vol. II. The Iron Age and the Persian Period." In. Jerusalem: Israel Antiquities Authority.

Colless, B. E. 2010. "Proto-Alphabetic Inscriptions from the Wadi Arabah." Antigou Oriente 8: 75-96.

- 2014. "The Origin of the Alphabet: An Examination of the Goldwasser Hypotheses." Antigua Oriente 12: 71-104.

Cross, F. M. 1962. "Yahweh and the God of the Patriarchs." Harvard Theological Review 55: 225-59.

. 1973. Canaanite Myth and Hebrew Epic: Essays in the History of the Religion of Israel. Cambridge: Harvard University Press.

Crüserman, F. 2002. "Human Solidarity and Ethnic Identity: Israel Self Definition in the Genealogical System of Genesis." In Ethnicity and the Bible, edited by M. Brett, 57-76. Leiden: Brill.

Černy, J. 1935. "Semites in Egyptian Mining Expeditions to Sinai." Ardin Orientalni 7: 384-9. Dahari, U. 2000. Monastic Settlement in Southern Sinai in the Byzantine Period: The Archaeological Remains. Jerusalem: Israel Antiquities Authority.

Darnell, J. C., F. W. Dobbs-Allsopp, M. Lundberg, P. K. McCarter, and B. Zuckerman. 2005. "Two Early Alphabetic Inscriptions from the Wadi El-Hôl: New Evidence for the Origin of the Alphabet from the Western Desert of Egypt." Annual of the American Schools of Oriental Research 59: 63-124.

Day, J. 2009. "Cain and the Kenites." In Homeland and Exile: Biblical and Ancient Near Eastern Studies in Honor of Oded Bustenay, edited by G. Galil, M. Geller, and A. Millard, 336-46. Leiden: Brill.

DeGear, E. B. 2015. For She Has Heard': The Standing Stone in Joshua 24 and the Development of a Convent Symbol. Sheffield: Phoenix Press.

De Vaux, R. (1958) 1961. Ancient Israel, Its Life and Institution. Translated by J. McHugh. London: Darton, Longman \& Todd.

- 1969. "Sur l'Origine Kénite ou Madianite du Yahwisme." Eretz-Israel. Archaeological, Historical and Geographical Studies 9: 28-32.

- . (1971) 1978. The Early History of Israel. Translated by D. Smith. London: Darton, Longman and Todd.

Dever, W. G. 1993. "Cultural Continuity, Archaeological Record and the Question of the Israelite Origins." Eretz Israel 24: 22*-33*. 
2003. Who Were the Early Israelites and Where Did They Come from? Grand Rapids: William Eerdmans.

. 2009. "Merenptah's 'Israel,' the Bible's and Ours." In Exploring the Longue Durée: Essays in Honor of Lawrence E. Stager, edited by D. Schloen, 89-96. Winona Lake: Eisenbrauns.

Donner, H., W. Röllig, and W. Röllig. 1968. Kanaanäische und aramäische Inschriften. 5th revised. Vol. 1. Wiesbaden: Harrassowitz Verlag.

Driver, G. R., and J. C. Miles. 1952-1955. The Babylonian Laws. Vols. I, II. Oxford: Oxford University Press.

Edelman, D. V. 1992. "Asher." In The Anchor Bible Dictionary, edited by D. N. Freedman, 1:482-3. New York: Doublday.

- 1995. "Edom: A Historical Geography." In You Shall Not Abhor an Edomite for He Is Your Brother: Edom and Seir in History and Tradition, edited by D. V. Edelman, 1-11. Atlanta: Society of Biblical Literature.

Eliade, M. 1956. The Forge and the Crucible. Chicago: Chicago University Press.

Eliade, Mircea. 1978. A History of Religious Ideas, Vol. I. From the Stone Age to the Eleusinian Mysteries. Chicago: Chicago University Press.

Faust, A. 2006a. Israel's Ethnogenesis: Settlement, Interaction, Expansion and Resistance. Approaches to Anthropological Archaeology. London: Equinox.

— 2006b. "The Negev Fortresses in Context: Reexaminating the Fortress Phenomenon in Light of General Settlement Processes of the Eleventh-Tenth Centuries B.C.E." Journal of the American Oriental Society 162: 135-60.

- 2015. "The Emergence of Iron Age Israel: On Origin and Habitus." In Israel's Exodus in Transdisciplinart Perspective, edited by T. Levy, T. Schneider, and W. H. C. Propp, 467-82. Heidelberg: Springer.

- 2018. "The Birth of Israel." In The Oxford Illustrated History of the Holy Land, edited by R. G. Hoyland and H. G. M. Williamson, 4-32. Oxford: Oxford University Press.

Faust, A., and S. Bunimovitz. 2003. "The Four Room House, Embodying Iron Age Israelite Society." Near Eastern Archaeolog 66: 22-31.

Finkelstein, I. 1988. The Archaeology of the Israelite Settlement. Jerusalem: Israel Exploration Society.

. 1994. "Emergence of Israel: A Phase in a Cyclical History of Canaan in the Third and Second Millennia BCE." In From Nomadism to Monarchy, edited by I. Finkelstein and N. Naaman, 152-78. Jerusalem: Yad Ben-Zvi.

— 2013. "Notes on the Historical Setting of Kuntilat "Ajrud." Maarav 20: 13-23. . 2014. "The Southern Steppe of the Levant ca. 1050-750 BCE: A Framework for a Territorial History." Palestine Exploration Quarterly 146: 89-104.

- 2015. "The Wilderness Narrative and Itineraries and the Evolution of the Exodus Tradition." In Israel's Exodus in Transdisciplinary Perspective: Text, Archaeology, Culture, and Geoscience, Quantitative Methods in the Humanities and Social Sciences, edited by T. E. Levy, T. Schneider, and W. H. C. Propp, 39-53. Cham: Springer.

Finkelstein, I., and A. Mazar. 2007. The Quest for the Historical Israel. Edited by B. Schmidt. Atlanta: Society of Biblical Literature.

Finkelstein, I., and N. A. Silberman. 2001. The Bible Unearthed: Archaeology's New Vision of Ancient Israel and the Origin of Its Sacred Texts. New York: Simon and Schuster.

Fitzmyer, J. A. 1967. The Aramaic Inscriptions of Sefire. Rome: Biblica et Orientalia. 
Forbes, R. J. 1950. Metallurgy in Antiquity: A Notebook for Archaeologists and Technologists. Leiden: Brill.

Freeman-Grenville, G. S. P. 2003. Eusebius of Caesarea, the Onomasticon: Palestine in the Fourth Century AD. Jerusalem: Carta.

Fritz, V., and A. Kempinski. 1983. Ergebnisse der Ausgrabungen auf der Hirbet ei-Masa (Tel Masos) 1972-1975. Wiesbaden: Harassowitz.

Galil, G. 2001. "The Jerahmeelites and the Negev of Judah." Journal of the Ancient Near Eastern Society 28: 33-42.

Gardiner, A. H. 1916. "The Egyptian Origin of the Semitic Alphabet." Journal of Egyptian Archaeology 3: 1-16.

. 1917. "The Tomb of Much-Travelled Theban Official." Journal of Egyptian Archaeology 4: 28-38.

. 1937. Late Egyptian Miscellanies. Bruxselles: Foundation egyptologique reine Elisabeth.

Gardiner, A. H., T. E. Peet, and J. Çerny. 1955. The Inscriptions of Sinai. Oxford: Oxford University Press.

Garfinkel, Y. 2018. “The Standing Stones.” In Khirbet Qeiyafa Vol. 4, Excavation Report 20092013: Art, Cult and Epigraphy, edited by Y. Garfinkel, S. Ganor, and M. Hasel, 4:55-100. Jerusalem: Israel Exploration Society.

Geraty, L. T. 2015. "Exodus Dates and Theories." In Israel's Exodus in Transdisciplinary Perspective: Text, Archaeology, Culture, and Geoscience. Quantitative Methods in the Humanities and Social Sciences, edited by T. E. Levy, T. Schneider, and W. H. C. Propp, 55-64. Heidelberg: Springer.

Gerstenberger, E. S. 1996. Yahweh the Patriarch: Ancient Image of God and the Feminist Theology. Translated by F. G. Gaiser. Minneapolis: Fortress Press.

Gilboa, A., T. A. J. Jull, E. Boaretto, and I. Sharon. 2009. "Note on the Iron Age IIA 14C Dates from Tell El-Qudeirat (Kadesh Barnea)." Tel Aviv 36: 82-94.

Giveon, R. 1964. “Toponymes ouest-asiatiques à Soleb.” Vetus Testamentum 14: 239-55.

- 1967. "The Shosu of Egyptian Sources and the Exodus." In Fourth World Congress of Jewish Studies, 1965, I:193-6. Jerusalem: World Union of Jewish Studies.

—. 1971. Les bédouins Shosou des documents Égyptiens. Leiden: Brill.

— 1978. The Stone of Sinai Speak. Tokyo: Gakuseisha.

—. 1981. "A New Kingdom Stela from Sinai." Israel Exploration Journal 31: 168-71.

Glueck, N. 1940. "Kenites and Kenizites." Palestine Exploration Quarterly 73: 22-24.

- 1968. Rivers in the Desert (Revised Edition). New York: Grove Press.

- 1970. The Other Side of Jordan. Cambridge: American School of Oriental Research.

- 1972. Edom. Encyclopedia Biblica Vol, I. Jerusalem, 91-103. Jerusalem: Bialik Institute.

Goedicke, H. 1994. “The Tetragram in Egyptian?” Journal of the Society for the Study of Egyptian Antiquities 24: 24-27.

Gogan, M. 2001. I Kings, New Translation with Introduction and Commentary. The Yale Anchor Bible: Yale University Press.

Goldwasser, O. 2006. "Canaanites Reading Hieroglyphs. Horus Is Hathor?-the Invention of the Alphabet in Sinai." Egypt \& Levant 16: 121-60.

- 2010. "How the Alphabet Was Born from Hieroglyphs." Biblical Archaeology Review 36: $38-51$.

. 2011. "The Advantage of Cultural Periphery: The Invention of the Alphabet in Sinai (Circa 1840 B.C.E.)." In Cultural Contacts and the Making of Cultures, Papers in Homage to 
Itamar Even-Zohar, edited by R. Sela-Sheffy and G. Toury, 255-322. Tel Aviv: Tel Aviv University Press.

- 2014. "Out of the Mists of the Alphabet - Redrawing the 'Brother of the Ruler of Retenu'." Ägypten Und Levante 24: 353-74.

- 2017. "Cuneiform and Hieroglyphs in the Bronze-Age Script Contact and the Creation of New Script." In Pharaoh's Land and Beyond: Ancient Egypt and Its Neighbors, edited by P. P. Creasman and R. H. Wilkinson, 183-93. Oxford: Oxford University Press.

Golub, M. R. 2020. "In the Name of the Father: Patronyms in Iron Age Ii Hebrew Epigraphy." Israel Exploration Journal 70: 36-48.

Golub, M. R., and R. 2015. "The Element שלם in Hebrew Personal Names in the Land of Israel During the Iron Age II Period." Vetus Testamentum 65: 567-87.

- 2017. "Israelite and Judean Theophoric Personal Names in the Hebrew Bible in the Light of the Archaeological Evidence." Ancient Near Eastern Studies 54: 35-46.

—. 2019. " 'United Monarchy' and 'Divided Monarchy' Personal Names Compared." Orientala Suecana 62-68: 57-64.

Gošič, M., and I. Gilead. 2015. "Unveiling Hidden Ritual: Ghassulian Metallurgy of the Southern Levant in Light of the Ethnographical Record." In Copper and Trade in the SouthEastern Mediterranean, edited by K. Rosinka-Balik, A. Ochal-Czarnowicz, M. Czarnowicz, and J. Debowska-Ludwin, 25-38. BAR Internationa Series 2753. Oxford.

Gottwald, N. K. (1979) 1999. The Tribes of Yahweh: A Sociology of the Religion of Liberated Israel. 1250-1050 BCE. Sheffield: Sheffield Academic Press.

Görg, M. 1982. "Punon- ein weiterer Distrikt der Š3sw." Biblische Notizen 19: 15-21.

Graf, D. 2004. "Nabataean Identity and Ethnicity: The Epigraphic Perspective." Studies in the History and Archaeology of Jordan 8: 145-54.

. 2007. "The Nabataeans Under Roman Rule (After AD 106)." In The World of the Nabataeans, edited by K. D. Politis, 2nd ed., 173-86. Stuttgart: Franz Steiner Verlag.

Grdseloff, B. 1947. "Édom, d'après les sources Égyptiennes." Revue de l'historie juive en Egypt 1: 69-99.

Grossmann, P. 1996. "Report on the Season in Firan-Sinai." Byzantische Zeitschrift 89: 11-37. - 2000. "Wadi Fayran/Sinai, Report on the Season in March and April 1985 and 1986 with an Appendix on the Church at Mount Moses." Annals Du Service Des Antiquites de L'Egypt 75: 153-71.

—. 2007. "Ein Bischofsstadt im südlichen Sinai: Pharan." In Begegnung mit der Vvergangenheit- 100 Jahre in Ägypten Deutsces Arcäologisches Instiut Kairo 1907-2007, edited by D. Guenter and P. Daniel, 88-92. Mainz: Philipp von Zabern.

Hadley, J. M. 2000. The Cult of Asherah in Ancient Israel and Judah. Cambridge: Cambridge University Press.

Halpern, B. 1992. "Kenites." In Anchor Bible Dictionary, edited by David N. Freedman, 4:17-22. New York: Doubleday.

Hamilton, G. J. 2006. The Origin of the West Semitic Alphabet in Egyptian Script. Washington, D. C: Catholic Biblical Association of America.

Hasel, M. G. 1994. "Israel in the Merneptah Stella." Bulletin of the American School of Oriental Research 296: 45-61.

. 2008. "Merenptah's Reference to Israel: Critical Issues for the Origin of Israel." In Critical Issues in Early Israelite History, edited by R. S. Hess, G. A. Klingbeil, and P. J. Ray, Jr, 47-59. Winona Lake: Eisenbrauns. 
Hauptmann, A. 2007. The Archaeometallurgy of Copper: Evidence from Faynan, Jordan. Berlin: Springer.

Healey, J. F. 1993. The Nabataean Tomb Inscriptions of Madain Salih. Oxford: Oxford University Press.

\section{- 2001. The Religion of the Nabataeans. Leiden: Brill.}

Helck, W. 1968. "Die Bedrohung Palaestinas durch einwan Gruppen am Ende der 18 und am Anfang der 19 Dynastie." Vetus Testamentum 18: 472-80.

—. 1971. Die Beziehungen Ägyptens zu Vorderasien. Wiesbaden: Otto Harrassowitz.

Hendel, R. S. 2002. "Israel Among the Nations." In Cultures of the Jews, A New History, edited by D. Biale, 43-76. New York: Schocken Books.

Herion, G. A. 1992. "Issachar." In The Anchor Bible Dictionary, edited by D. N. Freedman, 3:577. New York: Doubleday.

Herzog, Z., F. R. Brendfon, and A. Rainey. 1984. Beer Sheva II: The Early Iron Age Settlement. Tel-Aviv: Tel-Aviv University, Institute of Archaeology.

Hess, R. 2016. "Onomastics of the Exodus Generation in the Book of Exodus." In Did I Not Bring You Out of Egypt?: Biblical, Archaeological and Egyptological Perspectives on the Exodus Narratives, edited by J. K. Hoffmeier, A. R. Millard, and G. A. Rendsburg, 37-48. Winona Lake: Eisenbrauns.

Hoffmeier, J. K. 1997. Israel in Egypt: The Evidence for the Authenticity of the Exodus. New York: Oxford University Press.

- 2005. Israel in Sinai. Oxford: Oxford University Press.

- 2012. "Sinai in Egypt, Levantine and Hebrew (Biblical) Perspective." In The History of the Peoples of the Eastern Desert, edited by H. Bernard and K. Duistermaat. Los Angeles: University of California.

-. 2016. "Egyptian Religious Influence on the Early Hebrews." In Did I Not Bring You Out of Egypt?: Biblical, Archaeological and Egyptological Perspectives on the Exodus Naratives, edited by J. K. Hoffmeier, A. R. Millard, and G. A. Rendsburg, 3-36. Winona Lake: Eisenbrauns.

Hoffner, H. 1965. "The Elkunirsa Myth Reconsidered." Revue Hittite et Asianique 23: 5-16.

Holzer, A., and U. Avner. 2000. "Ma'aleh Eilat, 'Ein Netafim." Excavations and Surveys in Israel 111: 79.

Homan, M. M. 2002. To Your Tents O Israel the Terminology, Form and Symbolism of Tent in the Hebrew Bible and the Ancient Near East. Leiden: Brill.

Hooke, S. H. 1935. "A Scarab and Sealing from Tell Ed-Duweir." Palestine Exploration Quarterly 67: 195-7.

Ilan, Z. 1970. "'Way of the Wilderness' and 'Way of Mt. Seir'." Museum HaAretz Bulletin 12: $103-6$.

Jasmin, M. 2006. "The Emergence and First Development of the Arabian Trade Across the Wadi Arabah." In Crossing the Rift. Resources, Routes, Settlement Patterns and Interaction in the Wadi Arabah, edited by P. Bienkowski and K. Galor, 143-50. Oxford: Oxbow.

—. 2018. "Le premier métier du Dieu d'Israël." Le Monde de la Bible 227: 14-17.

Kawatoko, M. 1995. A Port City on the Sinai Peninsula Al-Tur, the 11th Expedition in 1994 (a Summary Report). Tokyo: Tokyo Publishing Co. Ltd.

Keel, O., and C. Uehlinger. 1992. Gods, Goddesses and Images of God in Ancient Israel. Translated by T. H. Trapp. Minneapolis: Fortress Press.

Kempinski, A. 1978. "Tel Masos." Expedition 20: 29-37. 
Kennedy, T. 2019. "The Land of the Š3sw (Nomads) of Yhw3 at Soleb." Dotawo: Journal of Nubian Studies 6: 175-92. https://escholarship.org/uc/item/07x6659z.

Killebrew, A. E. 2005. Biblical Peoples and Ethnicity: An Archaeological Study of Egyptians, Canaanites, Philistines, and Early Israel, 1300-1100 B.C.E. Archaeology and Biblical Studies 9. Atlanta: Society of Biblical Literature.

. 2006. "The Emergence of Ancient Israel: The Social Boundaries of a Mixed Multitude in Canaan." In I Will Speak the Riddles of Ancient Times Archaeological and Historical Studies in Honor of Amihai Mazar, Vol. II, edited by A. Maeir and P. de Miroschedji, II:555-72. Winona Lake: Eisenbrauns.

- 2017. "'Out of the Land of Egypt, Out of the House of Slavery . . ' (Exodus 20:2): Forced Migration, Slavery, and the Emergence of Israel."

King, P. 2009. "Slavery in Antiquity." In Exploring the Longue Durée: Essays in Honor of Lawrence E. Stager, edited by D. Schloen, 244-9. Winona Lake: Eisenbrauns.

Kitchen, K. 1979. Ramesside Inscriptions: Historical, Biographical. Vol. II. Oxford: Blackwell. - 1997. "The Physical Text of the Merneptah's Victory Hymn (the 'Israel Stela')." Journal of the Society for the Study of Egyptian Antiquities 24: 71-76.

—. 1998. "Egyptians and Hebrews, from Ra'amses to Jericho." In The Origin of Early IsraelCurrent Debates: Biblical, Historical and Archaeological Perspective, edited by S. Ahituv, 4164. Be'er Sheva: Ben Gurion University Press.

Klingbeil, M. 1999. Yahweh Fighting from Heaven: God as Warrior and as God of Heaven in the Hebrew Psalter and in the Ancient Near Eastern Iconography. Göttingen: Vanderhoeck and Ruprect.

Knauf, E. A. 1983. "Midianites and Ishmaelites." In Midian, Moab and Edom, edited by J. F. A. Sawyer, D. G. A. Clines, and D. G. A. Clines, 147-72. Sheffield: Journal of the Study of the Old Testament, Supplement Series 24.

- 1988. Midian. Untersuchungen zur Geschichte Palästinas und Nordarabiens am Ende des 2. Jahrtausends v.Chr. Abhandlungen des Deutschen Palästinavereins. Wiesbaden: Harassowitz.

Krahmalkov, C. 1994. "Exodus, Itinerary Confirmed by Egyptian Evidence." Biblical Archaeology Review 20: 54-62.

Kroker, Werner, Hans Günter Conrad, and Beno Rothenberg, eds. 1980. Antikes Kupfer im Timna-Tal: 4000 Jahre Bergbau und Verhüttung in der Arabah (Israel). Der Anschnitt Beiheft 1 . Bochum.

LaRocca-Pitts, E. 2001. Of Wood and Stone: The Significance of Israelite Cultic Items in the Bible and Its Early Interpreters. Winona Lake: Eisenbrauns.

Lemaire, A. 2007. The Birth of Monotheism: The Rise and Disappearance of Yahwism. Washington: Biblical Archaeology Society.

Lemche, N. P. 1998. The Israelites in History and Tradition. London: Society for Promotion of Christian Knowledge.

- 2013. Biblical Studies and the Failure of History. Sheffield: Equinox.

Lepsius, R. 1853. Egypt, Ethiopia and the Peninsula of Sinai. London: Henry G. Bohn.

Leuenberger, M. 2017. "Yahwh Province from the South." In The Origin of Yahwism, edited by J. van Oorschot, 157-80. Berlin: De Gruyer.

Leven, D., and B. Rothenberg. 2007. A Metallurgical Gemara: Metals in the Jewish Sources. London: The Institute for Archaeo-Metallurgical Studies. 
Levi, S. 1977. "An Old Tradition on the Summit of Jebel Musa in Sinai." Teva' V'aretz 19: 167-73.

-1980. Faith and Cult Among the Bedouins of Southern Sinai. Tel Aviv: The Society for the Protection of Nature.

Levy, S. 1987. The Bedouins in the Sinai Desert, a Pattern of Desert Society. Jerusalem: Schocken. Levy, T. E. 2009. "Pastoral Nomads and Iron Age Metal Production in Ancient Edom." In Nomads, Tribes and the State in the Ancient Near East, edited by J. Zuchamn, 147-78. Chicago: University of Chicago.

Levy, T. E., R. B. Adams, and A. Muniz. 2004. "Archaeology and the Shasu Nomads-Recent Excavations in the Jabal Hamrat Fidan, Jordan." In Le-David Maskil: A Birthday Tribute for David Noel Freedman, edited by W. H. C. Propp, R. E. Friedman, and R. E. Friedman, 63-89. Winona Lake: Eisenbrauns.

Levy, T. E., and A. F. C. Holl. 2002. "Migrations, Ethnogenesis, and Settlement Dynamics: Israelites in Iron Age Canaan and Shuwa-Arabs in the Chad Basin." Journal of Anthropological Archaeology 21: 83-118.

Levy, T. E., M. Najjar, and E. Ben-Yosef. 2014. New Insight into the Iron Age Archaeology of Edom, Southern Jordan, Vols. I, II. Los Angeles: University of California.

Levy, T. E., T. Schneider, and W. H. Propp, eds. 2015. Israel's Exodus in Trans-Disciplinary Perspective. Heidelberg: Springer.

Liphschitz, N. 2012. "The Botanical Remains." In Kuntilat 'Ajrud (Horvat Teman): An Iron Age II Religious Site on the Judah-Sinai Border, edited by Z. Meshel, 343-50. Jerusalem: Israel Exploration Society.

Lipinski, E. 2006. On the Skirt of Canaan in the Iron Age: Historical and Topographical Researches. Leuven: Peeters.

Liss, B., B. Lorentzen, C. Smitheram, M. Najjar, T. E. Levy, and M. Howland. 2020. "Up the Wadi: Development of an Iron Age Industrial Landscape in Faynan, Jordan." Journal of Field Archaeology. April April 2020: 1-15. https://doi.org/10.1080/00934690.2020.17 47792.

Littmann, E., and D. Merdith. 1953. "Nabataean Inscriptions in Egypt I." Bulletin of the School of Oriental and African Studies 15: 1-28.

Malul, M. 2010. Law Collections and Other Legal Compilations from the Ancient Near East. Haifa. Pardes.

Martin, M., 'A Eliyahu, M. Anenburg, Y. Goren, and I. Finkelstein. 2013. "Iron IIA SlagTempered Pottery in the Negev Highlands, Israel." Journal of Archaeological Science 40: 3777-92.

Marx, E. 1967. Bedouin of the Negev. New York: Praeger.

Mayerson, P. 1980. "The Ammonius Narrative: Bedouin and Blemmye Attack in Sinai." In The Bible World, Essays in Honor of Cyrus H. Gordon, edited by G. Rendsburg and Cyrus H. Gordon, 133-48. New York: Ktav Publisher House.

Mazar, 'A. 1981a. "Iron Age Fortresses in the Judaean Hills." Palestine Exploration Quarterly 114: 87-109.

. 1981b. "The Excavations at Khirbet Abu et-Twein and the System of Iron Age Fortresses." Judah. Eretz Israel 5: 229-49.

- 1985. "The Israelite Settlement in Canaan in the Light of Archaeological Excavations." In Biblical Archaeology Today: Proceedings of the International Congress on Biblical Archaeology, edited by J. Amitai, 61-71. Jerusalem: Israel Exploration Society. 
1990. Archaeology of the Land of the Bible. New York: Doubleday.

. 1999. "The 1997-1998 Excavations at Tel Rehov: Preliminary Report." Israel Exploration Journal 49: 1-42.

Mazar, 'A., and A. Mazar. 2007. "The Israelite Settlement." In I. Finkelstein, and A. Mazar. 2007. The Quest for the Historical Israel, edited by B. Schmidt and B. Schmidt, 85-98. Atlanta: Society of Biblical Literature.

Mazar, B. 1965. "The Sanctuary of "Arad and the Family of Hobab the Kenite." Journal of Near Eastern Studies 24: 296-303.

—. 1981. "Yahweh Came Out from Sinai." In Temples and High Places in Biblical Times, edited by A. Biran, 5-7. Jerusalem: Hebrew Union College.

McNutt, P. M. 1994. "The Kenites, the Midianites, and the Rechabites as Marginal Mediators in Ancient Israel." Semeia 67: 109-32.

Mendenhall, G. E. 1962. "The Hebrew Conquest of Palestine." Biblical Archaeologist 25: 66-87.

—. 1999. "Midian." In Anchor Bible Dictionary, edited by David N. Freedman, 4:815-18. New York: Doubleday.

- 2001. Ancient Israel's Faith and History: An Introduction to the Bible in Context. Louisville: John Knox Press.

Meshel, Z. 1978. Kuntilat 'Ajrud A Religious Center from the Time of the Judaean Monarchy on the Border of Sinai. Jerusalem: The Israel Museum.

—. 1981. "The History of 'Darb El-Ghaza'- the Ancient Road to Eilat and Southern Sinai." Eretz Israel 15: 358-71.

- 1983. "The Israelite Religious Centre of Kuntillet "Ajrud." Bulletin of the Anglo-Israel Archaeological Society 1982 (3): 52-55.

—, ed. 2012. Kuntilat 'Ajrud (Horvat Teman): An Iron Age II Religious Site on the Judah-Sinai Border. Jerusalem: Israel Exploration Society.

Mettinger, T. N. D. 1971. Solomonic State Officials. Lund: CWK Gleerup.

- 1982. "YHWH SABAOTH- the Heavenly King on the Cherubim Throne." In Studies in the Period of David and Solomon and Other Essays, edited by T. Ishida, 99-138. Tokyo: Yamakada-Shupansha.

- 1988. In Search of God. Translated by F. H. Cryer. Philadelphia: Fortress Press. . 1990. "He Elusive Essence: YHWH, El and Baal and the Distinctiveness of Israelite Faith." In Die Hebräische Bibel Und Ihre Zweifache Nachgeschichte, edited by E. Blum, C. Macholz, and E. W. Stegemann, 35-61. Neukirchen-Vluyn: Neukirchener Verlag.

- 1995. No Graven Image? Israelite Aniconism in Its Ancient Near Eastern Context. Stockholm: Almquist \& Wiksell International.

- 2006. "A Conversation with My Critics: Cultic Image or Aniconismin the First Temple?" In Essays on Ancient Israel in Its Near Eastern Context" A Tribute to Nadav Na'aman, edited by Y. Amit, E. Ben-Zvi, I. Finkelstein, and O. Lipschits, 273-96. Winona Lake: Eisenbrauns.

Millard, A. R. 2012. "The Alphabet." In Languages from the World of the Bible, edited by H. Gzella, 14-27. Winona Lake: Eisenbrauns.

Miroschedji, P. de. 1933. "Présence mémoire du désert: notes sur un theme rècurrent dans l'archéologie et l'history d'Israel." In Milieux et mémoire, edited by F. Alvarez-Péreyre, 51-87. Jerusalem: Centre de recherche Français a Jérusalem.

Moor, J. C. de. 1990. The Rise of Yahwism; the Roots of Israelite Monotheism. Leuven: Leuven University Press. 
Muchiki, Y. 1999. Egyptian Proper Names and Loanwords in North-West Semitic. Atlanta: Society of Biblical Literature.

Müller, S. R. 2015. "The Origins of YHWH in Light of the Earliest Psalms." In The Origin of Yahwism, edited by J. Van Ooeschot and M. Witte, 207-23. Berlin: De Gruyter.

Münger, S., and T. E. Levy. 2014. "The Iron Age Egyptian Amulet Assemblage." In New Insight into the Iron Age Archaeology of Edom, Southern Jordan, edited by T. E. Levy, M. Najjar, and E. Ben-Yosef, 741-65. Los Angeles: University of California.

Na'aman, N. 1980. "The Inheritance of the Sons of Simon." Zeitschrift Des Deutschen PalästinaVereins 96: 136-52.

- 1986. "Habiru and Hebrews: The Transfer of Social Term to the Literary Sphere." Journal of Near Eastern Studies 45: 271-88.

— 1992. "Israel, Edom and Egypt in the 10th Century B.C.E." Tel Aviv 19: 71-93.

2005. Canaan in the Second Millennium B.C.E. Winona Lake: Eisenbrauns.

. 2006. "No Anthropomorphic Graven Image, Notes on the Assumed Amthropomorphic Cult Statues in the Temples of Yhwh in the Pre-Exilic Period." In Ancient Israel's History and Historiography: The First Temple Period, Collected Essays, 3:311-38. Winona Lake: Eisenbrauns.

- 2013. "A New Outlook at Kuntilat "Ajrud and Its Inscriptions." Maarav 20: 39-51.

. 2015. "Judah and Edom in the Book of Kings and in Historical Reality." In New Perspective on Old Testament Prophecy and History, edited by R. I. Thelle, T. Stordalen, and M. E. J. Tichardson, 197-211. Leiden: Brill.

. 2016. "The Kenite Hypothesis in the Light of the Excavations at Horvat "Uza." In Not Only History: Proceeding of the Conference in Honor of Mario Liverani Held in SapienzaUniversita Di Roma, 20-21 April 2009, edited by G. Bartoloni and M. G. Biga, 171-82. Winona Lake: Eisenbrauns.

Naveh, J. 1982. Early History of Alphabet. Leiden: Brill.

Nebenzahl, K. 1986. Maps of the Holy Land. New York: Abbeville Press.

Negev, A. 1967. "New Dated Nabataean Graffiti from the Sinai." Israel Exploration Journal 17: 250-55.

. 1971. "New Graffiti from Sinai." Eretz Israel 10: 180-7.

1977a. "A Nabataean Sanctuary at Jebel Moneijah, Southern Sinai." Israel Exploration Journal 27: 219-31.

. 1977b. The Inscription of Wadi Haggag, Sinai. Qedem 6. Jerusalem: Institute of Archaeology, Hebrew University.

—. 1977c. "The Nabataeans and the Provincia Arabia." In Aufstieg Und Niedergang Der Römischen Welt, edited by H. Temporini and W. Haase, II:521-686. Berlin \& New York: Walter de Gruyter.

- 1991. Personal Names in the Nabataean Realm. Qedem 32. Jerusalem: Institute of Archaeology, Hebrew University.

Netzer, E. 1992. "Domestic Architecture in the Iron Age." In The Architecture of Ancient Israel from Prehistoric to the Persian Periods, edited by I. Dunayevsky, A. Kempinski, and R. Reich, 193-201. Jerusalem: Israel Exploration Society.

Niehr, H. 2013. "Kuntillet 'Ajrud and the Network of Phoenician Trade." Maarav 20: 27-38.

Noonan, B. J. 2016. "Egyptian Loanwords as Evidence for the Authenticity of the Exodus and the Wilderness Tradition." In Did I Not Bring You Out of Egypt?: Biblical, Archaeological 
and Egyptological Perspectives on the Exodus Narratives, edited by J. K. Hoffmeier, A. R. Millard, and G. A. Rendsburg, 49-68. Winona Lake: Eisenbrauns.

Nyström, S. 1946. Beduinentom und Yahwismus. Lund: Haken Ohlssons Boktrickeri.

Ornan, T. 2016. "Ketches and Final Work of Art: The Drawings and Wall Painting of Kuntilat "Ajrud Revisited." Tel Aviv 43: 3-36.

Pakkala, J. 2017. "The Origin of Yhwism from the Perspective of Deuteronomism." In The Origin of Yahwism, edited by J. van Oorschot, 267-82. Berlin: De Gruyer.

Palmer, E. H. 1871. The Desert of the Exodus. Cambridge: Deighton, Bell and Co.

Patrich, J. 1990. The Formation of Nabataean Art. Jerusalem: Magness.

Petrie, F. 1906. Researches in Sinai. London: John Murray.

Petrovich, D. 2016. The World Oldest Alphabet: Hebrew as the Language of the Proto-Consonanteal Script. Jerusalem: Carta.

Pfeiffer, H. 2017. "The Origin of Yhwh and Its Attestation." In The Origin of Yahwism, edited by J. van Oorschot, 115-44. Berlin: De Gruyer.

Pike, D. M. 1990. "Israelite Theophoric Personal Names in the Bible and Their Implications for Religious History." PhD dissertation, Philadelphia: University of Pennsylvania.

Prewitt, T. J. 1981. "Kinship Structures and the Genesis Genealogies." Journal of Near Eastern Studies 40: 87-98.

Rainey, A. F. 1995. "Unruly Elements in Late Bronze Canaanite Society." In Pomegranates and Golden Bells: Studies in Biblical, Jewish and Near Eastern Ritual, Law, and Literature in Honor of Jacob Milgrom, edited by D. Wright, D. Pearson, D. N. Freedman, and A. Hurvitz, 481-96. Winona Lake: Eisenbrauns.

—. 2001. "Israel in Merneptah's Inscription and Reliefs." Israel Exploration Journal 51: $57-75$.

- 2008a. "Inside-Outside: Where Did the Early Israelites Come from?" Biblical Archaeology Review 34: 45-50.

- 2008b. "Shasu or Habiru: Who Were the Early Israelites?" Biblical Archaeology Review 34: $51-55$.

- 2015. The El-Amarna Correspondence. Leiden: Brill.

Redford, D. B. 1986. "The Ashkelon Relief at Karnak and the Israel Stela." Israel Exploration Journal 36: 188-200.

- 1990. Egypt and Canaan in the New Kingdom. Edited by S. Ahituv. Beer Sheva: Ben Gurion University.

. 1992. Egypt, Canaan, and Israel in Ancient Times. Princeton: Princeton University Press.

Redmount, C. 2001. "Bitter Lives: Israel in and Out of Egypt." In The Oxford History of the Biblical World, edited by M. D. Coogan, 58-89. New York: Oxford University Press.

Reisner, G. A., C. S. Fisher, and D. G. Lyon. 1924. "Harvard Excavations at Samaria, 19081910" I: 227-46.

Rendsburg, G. A. 1997. "The Early History of Israel." In Crossing Boundaries and Linking Horizons, Studies in Honor of Michael C. Astour on His 80th Birthday, 433-53. Bethesda: CDL Press.

—. 2015. "Moses the Magician." In Israel's Exodus in Trans-Disciplinary Perspective, edited by T. E. Levy, T. Schneider, and W. H. Propp, 243-58. Heidelberg: Springer.

Robinson, E., and E. Smith. 1856. Biblical Researches in Palestine and the Adjacent Regions: A Journal of Travels in the Years 1838-1852. London: Murray.

Rothenberg, B. 1961. God's Wilderness: Discoveries in Sinai. London: Thames \& Hudson. 
1972. Timna, Valley of Biblical Copper Mines. London: Thames and Hudson. , ed. 1988. The Egyptian Mining Temple at Timna (Researches in the cArabah 1959-1984 Vol. 1). Vol. 1. London: Institute for Archaeo-Metallurgical Studies, Institute of Archaeology, University College London.

—. 1999a. "Archaeo-Metallurgical Researches in the Southern cArabah 1959-1990, Part 1: Late Pottery Neolithic to Early Bronze IV." Palestine Exploration Quarterly 131: 68-89. - 1999b. "Archaeo-Metallurgical Researches in the Southern cArabah 1959-1990, Part 2: Egyptian New Kingdom to Early Islam." Palestine Exploration Quarterly 131: 149-75. Rothenberg, B., and J. Glass. 1983. "The Midianite Pottery." In Midian, Moab and Edom, edited by J. F. A. Sawyer, D. G. A. Clines, and D. G. A. Clines, 65-124. Journal of the Study of the Old Testament, Supplement Series 24. Sheffield.

Römer, T. 2015. The Invention of God. Translated by R. Geuss. Cambridge: Harvard University Press.

Sapir-Hen, L., O. Lernau, and E. Ben-Yosef. 2018. "The Diet of Ancient Metal Workers: The Late Bronze and Early Iron Ages in the Arabah Valley (Timna and Faynan)." In Mining for Ancient Copper: Essays in Memory of Beno Rothenberg, edited by E. Ben-Yosef, 64-80. Tel Aviv: Tel Aviv University.

Sass, B. 1988. The Genesis of the Alphabet and Its Development in the Second Millennium BC. Wiesbaden: Otto Harrassowitz.

. 1991. Studia Alphabetica: On the Origin and Early History of the Northwest Semitic, South Semitic and Greek Alphabets. Göttingen: Vandenhoeck \& Ruprecht.

- 2006. The Genesis of the Alphabet and Its Development in the Second Millennium BC, Twenty Years Later. Wiesbaden: Otto Harrassowitz.

Savignac, M. R. 1933. "Chronique." Revue Biblique 42: 405-22.

Schneider, T. 1992. Asiatische Personennamen in ägyptischen Quellen des Neuen Reiches. Freiburg: Universitätsverlag.

- 2008. "The First Documented Occurrence of the God Yahweh? (Book of the Dead, Princeton Role 5).” Journal of Ancient Near Eastern Religions 7: 113-20.

— 2015. "Modern Scholarship Versus the Demon of Passover: An Outlook on Exodus Research and Egyptology Through the Lens of Exodus 12." In Israel's Exodus in TransDisciplinary Perspective, edited by T. E. Levy, T. Schneider, and W. H. Propp, 537-53. Heidelberg: Springer.

Schulman, A. 1976. "The Royal Butler Ramessesemperre." Journal of the American Research Centre in Egypt 13: 117-20.

- 1988. "Catalogue of the Egyptian Finds." In The Egyptian Mining Temple at Timna, edited by B. Rothenberg, 114-47. London: Institute for Archaeo-Metallurgical Studies, University College London.

Sell, E. 1914. "Image and Idols." In Encyclopedia of Religion and Ethics, edited by J. Hastings, VII:150-51. Edinburgh: T. \& T. Clark.

Shamir, O. 2014. "Two Special Traditions in Jewish Garments and the Rarity of Mixing Wool and Linen Threads in the Land of Israel." In Prehistoric, Ancient Near Eastern and Aegean Textiles and Dress: An Interdisciplinary Anthology, edited by M. Harlow, C. Michel, and M. L. Nosch, 297-308. Oxford: Oxbow.

- 2017. "The High Priest Sha'atnez Garments Compared to Textiles Found in the Land of Israel." In Textiles and Cult in the Ancient Mediterranean, edited by Cecilie Brøns and M. L. Nosch, 199-208. Oxbow, Oxford. 
Shiloh, Y. 1970. "The Four Room House: Its Situation and Function in the Israelite City." Israel Exploration Journal 20: 180-90.

Shupak, N. 1993. Where Can Wisdom Be Found?: The Sages Language in the Bible and in Ancient Egypt. Fribourg: Fribourg University Press.

- 2011. "The God from Teman and the Egyptian Sun God: A Reconstruction of Habakuk 3:3-7." The Journal of the Ancient Near Eastern Society 18: 97-116.

Simons, J. 1937. Handbook for the Study of Egyptian Topographical Lists Relating to Western Asia. Leiden: Brill.

Smith, M. 1990. The Early History of God: Yahweh and the Other Deities in Ancient Israel. San Francisco: Harper \& Row.

- 2006. The Rituals and Myths of the Feast of the Goodly Gods of KTU/CAT 1.23: Royal Construction of Opposition, Interaction, Integration and Domination. Atlanta: Society of Biblical Literature.

- 2017. "Yhwh's Original Character: Questions About an Unknown God." In The Origin of Yahwism, edited by J. Van Ooeschot and M. Witte, 23-44. Berlin: de Gruyter.

Sparks, B. 2015. "Egyptian Texts Relating to the Exodus: Discussions of Exodus Parallels in the Egyptology Literature." In Israel's Exodus in Trans-Disciplinary Perspective, edited by T. E. Levy, T. Schneider, and W. H. Propp, 259-81. Heidelberg: Springer.

Sparks, K. L. 2007. "Religion, Identity and the Origin of Ancient Israel." Religion Compass 1: 587-614.

Stadelmann, R. 2006. "Riding the Donkey: A Means of Transportation for Foreign Rulers." In Timelines Studies in Honour of Manfred Bietak, Vol. 2, edited by E. Czerny, I. Hein, H. Hunger, D. Melman, and A. Schwab, 301-4. Leuven: Peeters.

Stager, L. 1985. "Merneptah, Israel, and Sea Peoples: New Light on an Old Relief." Eretz Israel 18: $56-64$.

. 1989. "The Song of Deborah- Why Some Tribes Answered the Call and Other Did Not." Biblical Archaeology Review 15: 50-64.

Starcky, J. 1965. "Nouvelle Epitaphe Nabatéene." Revue Biblique 72: 95-97.

—. 1979. "Les Inscriptions Nabateennes du Sinai." Le Monde de la Bible 10: 37-41.

Stevenson, E. L. 1991. Claudius Ptolemy, the Geography. New York: Dover.

Stewart, F. H. 1988. Texts in Sinai Bedouin Law. Wiesbaden: Harrassowitz.

- 2003. "The Contract with Surety in Bedouin Customary Law." UCLA Journal of Islamic and Near Eastern Law 2: 163-280.

Stone, M. 2017. Uncovering Ancient Footprints. Atlanta: Society of Biblical Literature.

Stone, M. E., ed. 1992. Rock Inscriptions and Graffiti Project. Catalogue of Inscriptions, Vol. 2, \#3001-6000. Atlanta: Scholar Press.

—, ed. 1994. Rock Inscriptions and Graffiti Project. Catalogue of Inscriptions, Vol. 3, \#60018500. Atlanta: Scholar Press.

Strawn, B. A., and J. M. LeMon. 2018. "Religion in Eighth-Century Judah: The Case of Kuntillet 'Ajrud (and Beyond)." In Archaeology and History of Eight Century Judah, edited by Z. I. Farber and J. L. Wright, 379-400. Atlanta: SBL Press.

Sukenik, N., D. Iluz, Z. Amar, A. Varvak, V. Workman, O. Shamir, and E. Ben-Yosef. 2017. "Early Evidence (Late 2nd Millennium BCE) of Plant-Based Dyeing of Textiles from Timna, Israel." Plos One 12 (6). https://doi.org/10.1371/journal.pone.0179014.

Sukenik, N., D. lluz, Z. Amar, A. Varvak, O. Shamir, and E. Ben-Yosef. 2021. "Early Evidence of Royal Purple Dyed Textile from Timna Valley (Israel)." Plos One 16: 1-23. 
Tallet, P. 2012. La zone minière pharaonuque du Sud Sinai I. 2 vols. Cairo: Institute Français d'archaéologie orientale.

Tallet, P., C. Castel, and P. Fluzin. 2011. "Metallurgical Sites of Southern Sinai (Egypt) in the Pharaonic Era: New Discoveries." Paléorient 37: 79-89.

Tebes, J. 2006. "Iron Age 'Negevite' Pottery: A Reassessment." Antiguo Oriente 4: 95-118.

- 2007a. "A Land Whose Stones Are Iron, and Out of Whose Hills You Can Dig Copper. The Exploitation and Circulation of Copper in the Iron Age Negev and Edom." DvarLogos 6: 69-91.

- 2007b. "Pottery Makers and Premodern Exchange in the Fringes of Egypt: An Approximation to the Distribution of Iron Age Midianite Pottery." Buried History 43: 11-26.

- 2009. "'You Shall Not Abhor an Edomite, for He Is Your Brother': The Tradition of Esau and the Edomite Genealogies from an Anthropological Perspective." In Perspectives in Hebrew Scriptures 3, edited by E. Ben Zvi, 175-216. Piscataway: Gorgias Press.

Tebes, J. M. 2017. "The Southern Home of Yhwh and Pre-Priestly Patriarchal/Exodus Tradition from a Southern Perspective." Biblica 98: 166-88.

— 2020. "Midian." In Oxford Bibliographies in Biblical Studies, edited by Christopher Matthews. New York: Oxford University Press. https://www.oxfordbibliographies.c om/view/document/obo-9780195393361/obo-9780195393361-0271.xml.

Teixidor, J. 1998. "Les Nabatéens du Sinaï.” In Le Sinaï durant l'antiquité et le moyen-âge, edited by D. Valbelle, 83-87. Paris: Errance.

Thompson, T. 1999. The Mythic Past. London: Jonathan Cape Random House.

Tigay, J. H. 1987. "Israelite Religion: The Onomastic and Epigraphic Evidence." In Ancient Istaelite Religion: Essays in Honor of Frank Moore Cross, edited by S. D. McBride, P. D. Miller, and P. D. Hanson, 157-94. Philadelphia: Fortress Press.

Toorn, K. van der. 1995. "Yahweh." In Dictionary of Deities and Demons in the Bible, edited by K. van der Toorn, B. Becking, and P. W. van der Horst, 1711-30. Leiden: Brill.

— 1997. "Worshiping Stones: On the Deification of Cult Symbol." Journal of North-West Semitic Languages 23: 1-14.

Tsafrir, Y. 1988. Excavations at Rehovot-in-the-Negev, I: The Northern Church. Vol. 25. Qedem. Jerusalem: Institute of Archaeology, Hebrew University.

Vaelske, V., and M. Bode. 2019. "Early Iron Age Copper Trails: First Results of a Pilot-Study at Sidon." Archaeology \& History in Lebanon 48-49: 130-33.

Vassiliev, A. 2006. "The Localization of the Shasu-Land of Ramses II's Rhetorical Text." In Current Research in Egyptology 2006, edited by N. Cannata, 163-8. Oxford: Oxbow.

Veen, P. van der, C. Theis, and M. Görg. 2010. "Israel in Cana'an (Long) Before Pharaoh Merenptah: A Fresh Look at Berlin Statue Pedestal Relief 21687." Journal of Ancient Egyptian Interconnections 2: 15-25.

Ward, A. W. 1972. "The Shasu Bedouin: Notes on a Recent Publication." Journal of the Economic and Social History of the Orient 24: 35-60.

Ward, D. W. 2015. The Mirage of the Saracen: Christian and Nomads in Sinai Peninsula in Late Antiquity. Oakland: University of California Press.

Weinfeld, M. 1987. "The Tribal League at Sinai." In Ancient Israelite Religion: Essays in Honor of Frank Moore Cross, edited by P. D. Miller, P. D. Hanson, and S. D. McBride, 303-14. Philadelphia: Fortress Press.

Weippert, M. 1971. The Settlement of the Israelite Tribes in Palestine: A Critical Survey of Recent Debates. London: S.C.M. Press. 
1974. "Semitische Nomadendes zweiten jahrtausends: Über die der ägyptischen Quellen." Biblica 55: 265-80, 427-33.

Wenning, R. 1987. Die Nabatäer-Denkmäler und Geschichte: ein Bestendesaufnahme des archäeologischen Befundes. Freiburg: Universitätsverlag Freiburg.

Wensinck, A. 1978. "Kaynuka." In Encyclopedia of Islam, edited by C. E. Bosworth, E. van Donzel, W. P. Heinrichs, and G. Lecomte, 4:824. Leiden: Brill.

Williams. 1973. "Scribal Training in Ancient Egypt." Journal of the American Oriental Society 92: 214-21.

Wilson, C.W: 1880. Picturesque Palestine, Sinai and Egypt. Vol. IV. New York: Appleton.

Wilson, C. W., and R. E. Palmer. 1869. Ordnance Survey of the Peninsula of Sinai. London: Ordnance Survey.

Wimmer, S. J. 2018. "A Proto Sinaitic Inscription from Timna/Israel: New Evidence on the Emergence of Alphabet." Journal of Egyptian Interconnections 2: 1-12.

Workman, V., O. Shamir, N. Sukenik, M. Gleba, and E. Ben-Yosef. 2017. "The Central Timna Valley Project: 5 Years of Ongoing Textile Research." Archaeological Textiles Review 59: 67-70.

Wright, G. E. 1957. Biblical Archaeology. London: Duckworth.

Yadin, Y. 1965. "And Dan, Why Do You Dwell in Ships?" In Western Galilee and the Costal Galilee, edited by J. Aviram, 42-55. Jerusalem: Israel Exploration Society.

- 1982. "Is the Biblical Account of the Israelite Conquest of Canaan Historically Reliable?" Biblical Archaeology Review 8: 16-23.

Yahalom-Mack, N., Y. Gadot, 'A. Eliyahu-Behar, S. Becher, S. Shilstein, and I. Finkelstein. 2014. "Metalworking at Hazor: A Long-Term Perspective." Oxford Journal of Archaeology 33: 19-45.

Yahalom-Mack, N., M. A. S. Martin, O. Tirosh, Y. Erel, and I. Finkelstein. 2015. "Lead Isotope Analysis of Slag-Tempered Negev Highlands Pottery." Antiguo Oriente, no. 13: 83-98.

Yahalom-Mack, N., and I. Segal. 2010. "Chemical and Lead Isotope Analysis of Copper-Based and Lead Artifacts." In Tel Rehov, A Bronze and Iron Age City in the Beth-Shean Valley, Vol. $V$. Various Objects and Natural-Science Studies, edited by N. Panitz-Cohen and A. Mazar, 42-51. Jerusalem.

- 2011. "Provenancing Five Copper-Based Artifacts." In Dan III: Avraham Biran Excavations, 1966-1999: The Late Bronze Age, edited by R. Ben-Dov, 367-73. Jerusalem.

Yurco, F. J. 1997a. "Merenptah's Wars, the 'Sea Peoples," and Israel's Origins." In Merne: Studies in Honour of Martha Rhoads Bell, edited by J. Phillips, 497-506. London: Van Siclen Books.

— 1997b. "Merneptah's Canaanite Campaign and Israel's Origins." In Exodus: The Egyptian Evidence, edited by E. S. Frerichs and L. H. Lesco, 27-55. Winona Lake: Eisenbrauns.

Zayadine, F. 1990. "The Pantheon of the Nabataean Inscriptions in Egypt and the Sinai." Aram 2: $151-74$.

Zertal, A. 1987. "An Early Iron Age Cultic Site on Mt. Ebal: Exavation Seasons 1982-1987: Preliminary Report." Tel Aviv 13-14: 105-65.

- 1991. "Israel Enters Canaan: Following the Pottery Trail." Biblical Archaeology Review 17: $28-49$.

- 1994. " 'To the Lands of the Perizzites and the Giants': On the Israelite Settlement in the Hill Country of Manasseh." In From Nomadism to Monarchy: Archaeological and His- 
torical Aspects of Early Israel, edited by I. Finkelstein and N. Na'aman, 47-69. Jerusalem: Israel Exploration Society.

Zevit, Z. 2001. The Religions of Ancient Israel: A Synthesis of Paralytic Approach. London: Continuum.

Zuchman, J. 2009. "Integrating Approach to Nomads, Tribes and the State in the Ancient Near East." In Nomads, Tribes and the State in the Ancient Near East, edited by J. Zuchman, 1-13. Chicago: University of Chicago.

Zwickel, W., and P. G. van der Veen. 2017. "The Earliest Reference to Israel and Its Possible Archaeological and Historical Background." Vetus Testamentum 67: 129-40. 